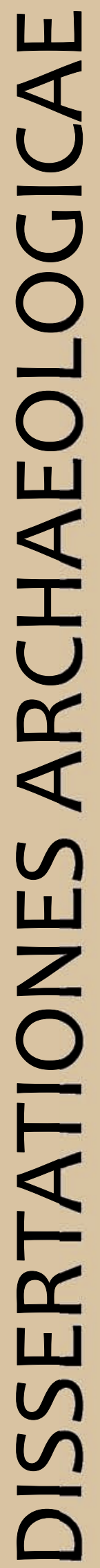

ex Instituto Archaeologico Universitatis de Rolando Eötvös nominatae

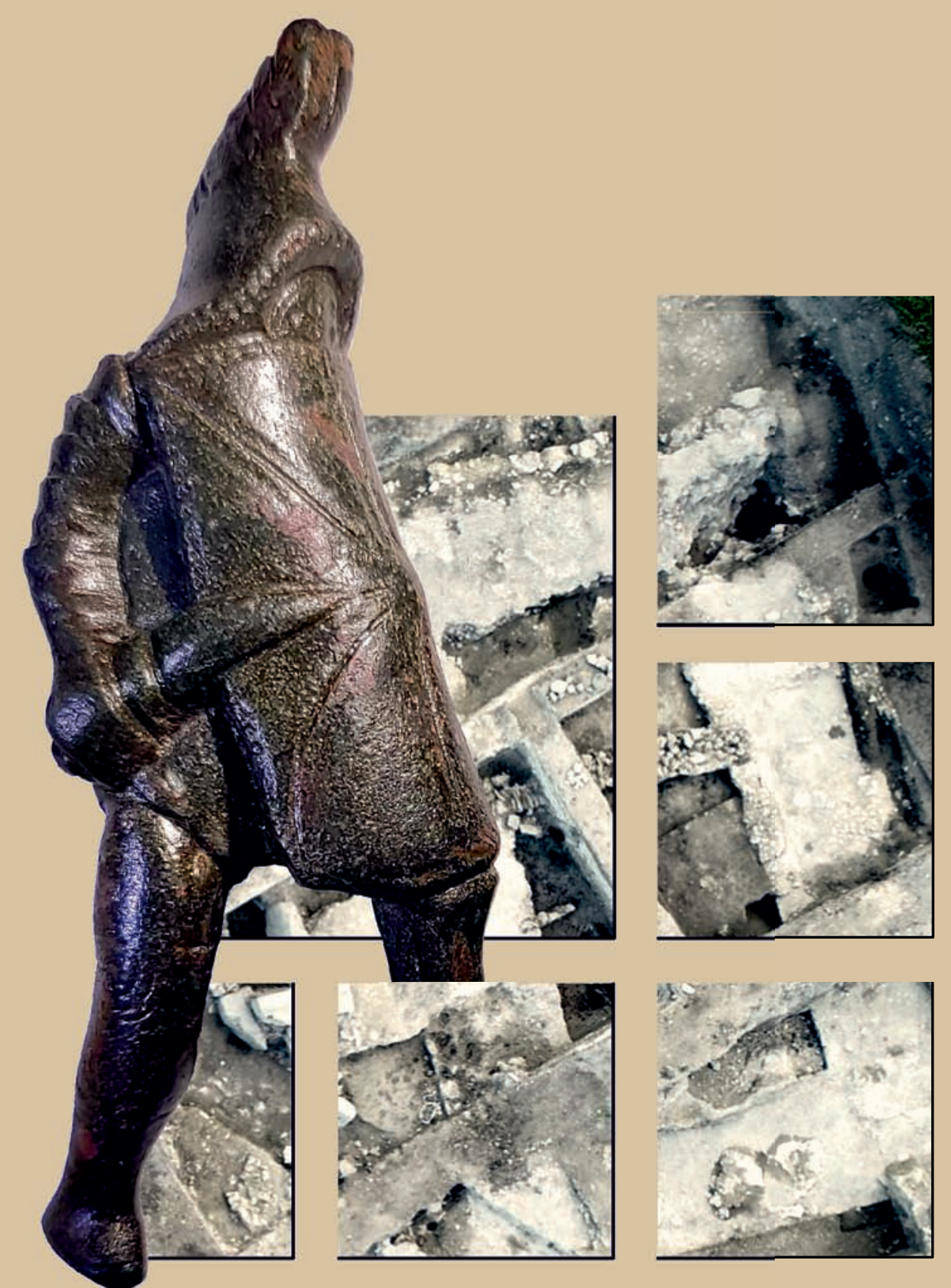

$$
\text { Ser. 3. No. 7. } 2019
$$




\section{Dissertationes Archaeologicae ex Instituto Archaeologico}

Universitatis de Rolando Eötvös nominatae Ser. 3. No. 7.

Budapest 2019 
Dissertationes Archaeologicae ex Instituto Archaeologico Universitatis de Rolando Eötvös nominatae

Ser. 3. No. 7.

Editor-in-chief:

DÁvid BARTUS

Editorial board:

LÁsZló BARTOSIEWICZ

LÁSZLÓ BORHY

ZOLTÁN CZAJLIK

IsTVÁN FELD

GÁBOR KALLA

PÁL RACZKY

MikLÓs SzABÓ

TivadAR VidA

Technical editor:

GÁBOR VÁCZI

Proofreading:

SZILVIA BARTUS-SZÖLLősI

ZsóFIA KondÉ

Aviable online at http://dissarch.elte.hu

Contact: dissarch@btk.elte.hu

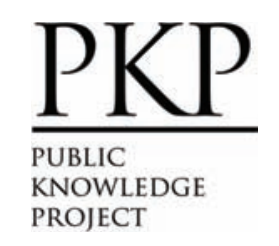

๑ ELTE Eötvös Loránd University, Institute of Archaeological Sciences

Layout and cover design: Gábor Váczi

Budapest 2019 


\section{CONTENTs}

\section{ARticles}

János Gábor TARBAY

The Casting Mould and the Wetland Find - New Data on the Late Bronze Age

Peschiera Daggers

Máté MeRvel

Late Bronze Age stamp-seals with negative impressions of seeds from Eastern Hungary

János Gábor TARBAY

Melted Swords and Broken Metal Vessels - A Late Bronze Age Assemblage

from Tatabánya-Bánhida and the Selection of Melted Bronzes

Ágnes ScHNEIDER

Multivariate Statistical Analysis of Archaeological Contexts: the case study

of the Early La Tène Cemetery of Szentlörinc, Hungary

Csilla SÁRÓ - Gábor LASSÁNYI

Bow-tie shaped fibulae from the cemetery of Budapest/Aquincum-Graphisoft Park

Dávid BARTus

Roman bronze gladiators - A new figurine of a murmillo from Brigetio

Kata DÉvAI

Re-Used Glass Fragments from Intercisa

Bence Simon

Rural Society, Agriculture and Settlement Territory in the Roman, Medieval and Modern Period Pilis Landscape

Rita RAKONCZAY

„Habaner“ Ofenkacheln auf der Burg Čabrad”

\section{FIELD REPORT}

Bence Simon - Anita Benes - Szilvia Joháczi - Ferenc BARnA

New excavation of the Roman Age settlement at Budapest dist. XVII, Péceli út (15127) site 


\section{Thesis Abstracts}

Kata SzILÁGYi

Die Silexproduktion im Kontext der Südosttransdanubischen Gruppe

der spätneolithischen Lengyel-Kultur

Norbert FARAGÓ

Complex, household-based analysis of the stone tools of Polgár-Csőszhalom

János Gábor TARBAY

Type Gyermely Hoards and Their Dating - A Supplemented Thesis Abstract

Zoltán Havas

The brick architecture of the governor's palace in Aquincum

Szabina Merva

'...circa Danubium...' from the Late Avar Age until the Early Árpádian Age-

$8^{\text {th }}-11^{\text {th }}$-Century Settlements in the Region of the Central Part of the Hungarian

Little Plain and the Danube Bend

Szabolcs Balázs NAGY

Noble Residences in the $15^{\text {th }}$ century Hungarian Kingdom - The Castles of Várpalota,

Ujlak and Kisnána in the Light of Architectural Prestige Representation

Ágnes KollátH

Tipology and Chronology of the early modern pottery in Buda 


\title{
Multivariate Statistical Analysis of Archaeological Contexts: the case study of the Early La Tène Cemetery of Szentlörinc, Hungary
}

\author{
ÁgNes SCHNEIDER \\ Philipps-Universität Marburg \\ euboia@gmail.com
}

\begin{abstract}
This study would like to provide an open-source and reproducible workflow for multivariate statistical analysis of archaeological contexts, e.g. cemeteries. Further the study does not wish to republish the cemetery - it only discusses diagnostic artifact types which can be used for dating this specific cemetery.

Also, the study shows that multivariate statistical analysis can be useful and that a bigger sample size (cemetery), higher number of artifacts and more associated artifact types in closed contexts can deliver better and more useful information for dating cemeteries or even building regional chronologies.
\end{abstract}

\section{Introduction}

Quantitative methods in archaeology reach back to the end of the $19^{\text {th }}$ century, when Sir Flinders Petrie applied the so-called strip-method in 1899 for the first time on material from different Egyptian cemeteries. This combinatorial technique was performed by hand until late in the second half of the $20^{\text {th }}$-century - mainly until the first application of statistical-mathematical methods to computers and the emergence of Correspondence Analysis from the toolbox of multivariate statistics, though Seriation - that is the combinatorial technique was more persistent in German-speaking regions as in Anglo-Saxon areas. ${ }^{1}$ Soon quantitative methods have become computer-based. A good example is GolDMANn 1979, where the workflow is traceable in the published script. The development of computing soon enabled the development of statistical software applications for various fields and disciplines which have been used and adopted for quantitative archaeological analysis. Today we can choose from a variety of tools: SPSS, ${ }^{2}$ WinBASP, ${ }^{3}$ PAST, ${ }^{4}$ Canoco, ${ }^{5}$ WINSERION ${ }^{6}$ and the Excel extension CAPCA. ${ }^{7}$

1 EgGERT et al. 2012, 206.

2 A proprietary software by IBM, with a reasonable offer for students.

3 The Bonn Archaeological Software Package, developed by Irwin Scollar, Irmela Herzog and other contributors since 1973 is a collection of more that 70 functions, including Seriation and Correspondence Analysis. The program was last revised in 1997 (http://www.uni-koeln.de/ al001/basp.html). It is only available for Windows XP or Windows 32 bit WM.

4 The Paleontological Statistics software, which is a follow-up of PALSTAT, includes various statistical algorithms and visualisation options which are continuously growing since 2001, today managed by Øyvind Hammer. PAST is more or less self-explanatory and comes with a descriptive tutorial. https://folk.uio.no/ohammer/past/

5 Canonical Correspondence Analysis, developed for Ecological Vegetation Analysis, by Prof. Dr. Cajo J. F. ter Braack at the University of Wageningen. https://www.wur.nl/nl/show/Canoco-brengt-ordening-in-ecologische-data.htm

6 The "Serion Suite" is being developed by Peter Stadler, Naturhistorisches Museum and Universität Wien. It is a combined software-suite which functions as a database, image-editor (Image Database Montelius), artifact mapper and statistical analysis tool for archaeological data. The tools are only open for project participants. http://www.winserion.org/index.html

7 CAPCA is an add-in for Excel for computing Principal Components Analysis (PCA), Correspondence Analysis (CA) and Metric Scaling (MS), developed by Torsten Madsen. It computes the data in the worksheets and produces results in worksheets and charts. http://www.archaeoinfo.dk/capca.htm 
Furthermore open-source scripting languages have been conquered for archaeological use, among others Pearl, Python and $R$. Undertaking quantitative analysis in open-source scripting environments has several benefits: most of all a great deal of resources (packages, tutorials, case studies) and most of all reproducible and open access code. On this basis this study used the scripting language R with its GUI RStudio. ${ }^{8}$ Present study aims to provide reproducible code for some aspects of multivariate statistical analysis of archaeological cemeteries. ${ }^{9}$ The cemetery analyzed is Szentlörinc, excavated and published in 1968 by Erzsébet Jerem. ${ }^{10}$ The paper is built up of three parts: the outline of the used methods, the analysis of the cemetery and the conclusion with an assessment of the combined analysis method.

\section{Quantifying Szentlőrinc}

Using quantitative methods requires us to abstract and formalize the archaeological artifacts we are dealing with. Multivariate statistical methods enable us to deal with multiple variables at once, e.g. Ordination methods, which are means of Exploratory Data Analysis (EDA) - that is the visualization of the coherence of data without being interential, but still delivering several modi to examine the statistical variability of the results. ${ }^{11}$ Several Ordination methods exist, of which Correspondence Analysis, Seriation and (hierarchical) Cluster Analysis are being used in this study.

The data is organized as an $m: n$ presence-absence matrix, where $m$ stands for the graves and $n$ for the artifacts. The entities/sites to be grouped or "ordinated" are the graves and the variables are the number of artifacts. When dealing with distinct artifact types, e.g only the fibulae, all specimens of these artifacts were used in the analysis.

\section{Correspondence Analysis (CA)}

Over the half century of existence of the Correspondence Analysis, originally developed by the french linguist and statistician Paul Benzécri in the 1960's, ${ }^{12}$ it has been refined to several variants (e.g. Multiple Correspondence Analysis, Joint Multiple Correspondence Analysis, ${ }^{13}$ Detrended Correspondence Analysis and Canonical Correspondence Analysis) extrapolated from "reciprocal averaging". ${ }^{4}$

Correspondence analysis projects categorical data (presence-absence as well as contingency tables/frequency distribution of attributes) in an n-dimensional hyperspace through dimension-reduction simplifying the data to the most meaningful dimensions. Coherent data will appear more closely to each other. ${ }^{15}$ Correspondence Analysis (and Multiple Correspondence

$8 \mathrm{R}$ is an open-source statistical software based on the S programming language and is used widely for statistical analysis in Ecology, Biodiversity, Biogeography, Psychological and archaeological research. R Core Team (2019). R: A language and environment for statistical computing. R Foundation for Statistical Computing, Vienna, Austria. URL https://www.R-project.org/.

9 The code is available on Github: https://github.com/keltoskytoi/Multivariate_Statistics_Szentloerinc

10 JEREM 1968.

11 Eggert et al. 2012, 222; Greenacre 2006, 180.

12 NenAdić - Greenacre 2007, 1.

13 These two variants were refined by a student of Benzécrí, M. Greenacre. For the methods see: GREENaCre 1984; Greenacre 1991; Greenacre 2005; Greenacre 2006; NenAndić - Greenacre 2007; D’EnZA Greenacre 2012; Greenacre - Primicero 2013.

15 GREENACRE 2005. 
Analysis) is viewed as an adaption of the Principle Component Analysis (PCA) to categorical data. ${ }^{16}$ The Chi-squared distance $\left(\mathrm{X}^{2}\right)$ is used as an overall measure for the entities and variables. Subsequently the standardized residuals (situated in a 3D space) are broken down by singular value decomposition to be able to represent them in a $2 \mathrm{D}$ space, that is in few(er) dimensions/axes. ${ }^{17}$

\section{Seriation}

Seriation works with the similarity of the attributes of entities and on this basis portrays patterns in data. As in Correspondence Analysis, entities sharing similar attributes are located nearer to each other than those that display different attributes. Seriation was done in Germany by hand until the pioneer work of Klaus Goldmann in $1979 .{ }^{18}$ The result of a Seriation is a reorganized combination matrix, in which the ordination runs diagonally from top left to bottom right. ${ }^{19}$ It is a relative combination sequence and can be used to assess the linkage of the artifacts. The archaeologist interpreting the results has to assess if the cohesion is chronological, which is not always the case. There is a fundamental relationship between Seriation and Correspondence Analysis: the $1^{\text {st }}$ axis of the Correspondence Analysis is used to extract a Seriation.

\section{Cluster Analysis}

Cluster Analysis is also grouping similar entities together, on the basis of one or more variables. Several clustering approaches exist - in this study the polythetic-agglomerative or hierarchical-agglomerative classification (HAC) approach was used. ${ }^{20}$ The HAC approach is based on a distance measure between entities and is graphically represented in dendrograms. The length of the branches of the dendrograms represent the dissimilarity between entities. The most common clustering algorithm is UPGMA (unweighted pair group method using arithmetic means) which is working with group average, which means that the cluster similarity is defined on the basis of the average distance between group members. This clustering algorithm is used throughout the study, because it is supposed to outweigh the negative traits of other clustering algorithms.

To have a deeper insight to these (and other) multivariate statistical methods, FLETCHER Lock 2005, Leyer - Wesche 2007, Drennan 2009, Eggert et Al. 2011, Siegmund 2015 and CARLSON 2017 is recommended. The main R-packages used in this study are: vegan, ca, quantAAR, varnastats and ggplot2.

\section{Exploring Szentlőrinc}

\section{The Late Hallstatt - Early La Tène cemetery of Szentlörinc}

The cemetery is situated in South-West Hungary, in county Baranya, just about $20 \mathrm{~km}$ to the west of Pécs. The first investigation started in 1950 when stray-finds came to light during

16 D'EnZa - GreEnACre 2012, 454.

17 CARLSON 2017, 280.

18 Goldmann 1979.

19 In our case the whole combination matrix is going to be skewed because of the settings of the R packages. This will be pointed out at the appropriate place.

20 Leyer -Wesche 2007, 159-170; CARLSON 2017, 318-345; Drennan 2009, 309-320. 
clay extraction: J. Dombay excavated 4 graves between the $25^{\text {th }}$ and $28^{\text {th }}$ April in 1950 . No documentation, except for the information of the position of the graves exists. The next intervention took place in 1962 when 4 other graves were excavated at right angles from the trial trench of J. Dombay by V. Kováts. On the basis of the finds, the systematic excavation of the cemetery followed in 1963, 1965 and 1966, continuing the method of trial-trenching. This method led to the result, that it was possible to localize the limits of the cemetery. ${ }^{21}$

From the 72 graves uncovered in Szentlörinc, 53 are inhumations, 8 cremations and 4 cenotaphia. 6 other graves yielded horses (see Tab. 1). Exploratory Data analysis can help to make certain traits of the archaeological material visible.

We can altogether say that 22 graves contain any grave goods and 39 can be understood as disturbed on the basis of the grave descriptions. ${ }^{22}$ Thus we can conclude, that graves 5, 8, 14, 23, $25,37,47,49,50,57,64,66,68,69,70,71$, and 72 seem to have been robbed and only graves 1 , 4,17 and 45 seem to have been without any grave goods. Graves 6, 7, 8, 9, 13, 25 and 28 are described to be in a bad state of preservation. The mixed conditions of the preservation state and disturbances makes it hard to determine if a grave was robbed/disturbed or poorly furnished.

Altogether we can deal with 42 artifact types in the cemetery. The next plots show the presence of artifact types in Szentlörinc (Fig. 1) and the number of artifact types per grave (Fig. 2). We can see that 11 artifact types are only present once in the cemetery and there are 4 graves, which only have one artifact type. If we eliminate the types which are present only once and the graves which contain only one artifact, then we come down to 31 types which are present more than once in 36 graves, which contain more than one artifact type (Figs 3, 4). As Fig. 2,

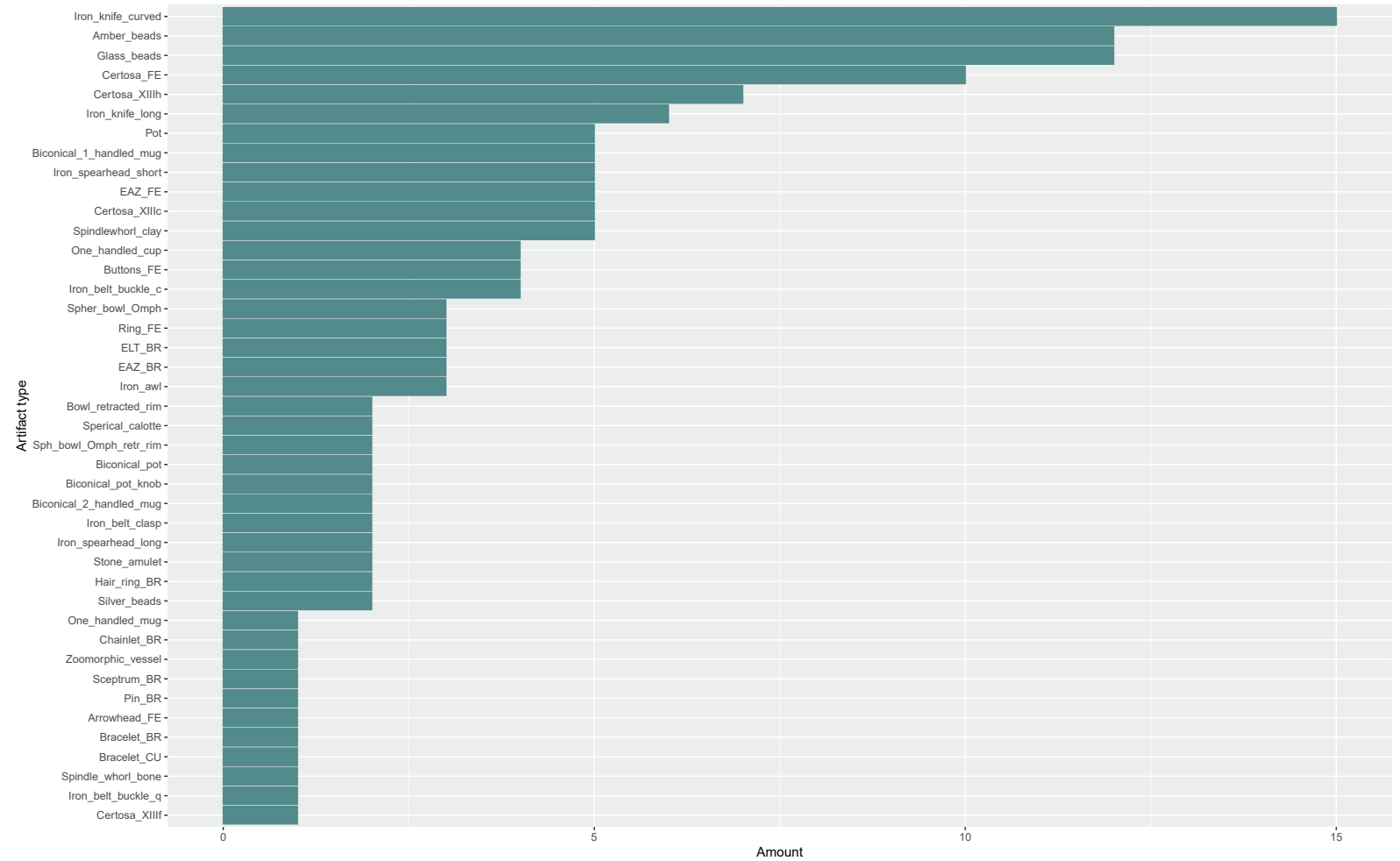

Fig. 1. The presence of artifact types in the cemetery of Szentlörinc.

21 JEREM 1968, 159.

22 JEREM 1968, 161-174. 


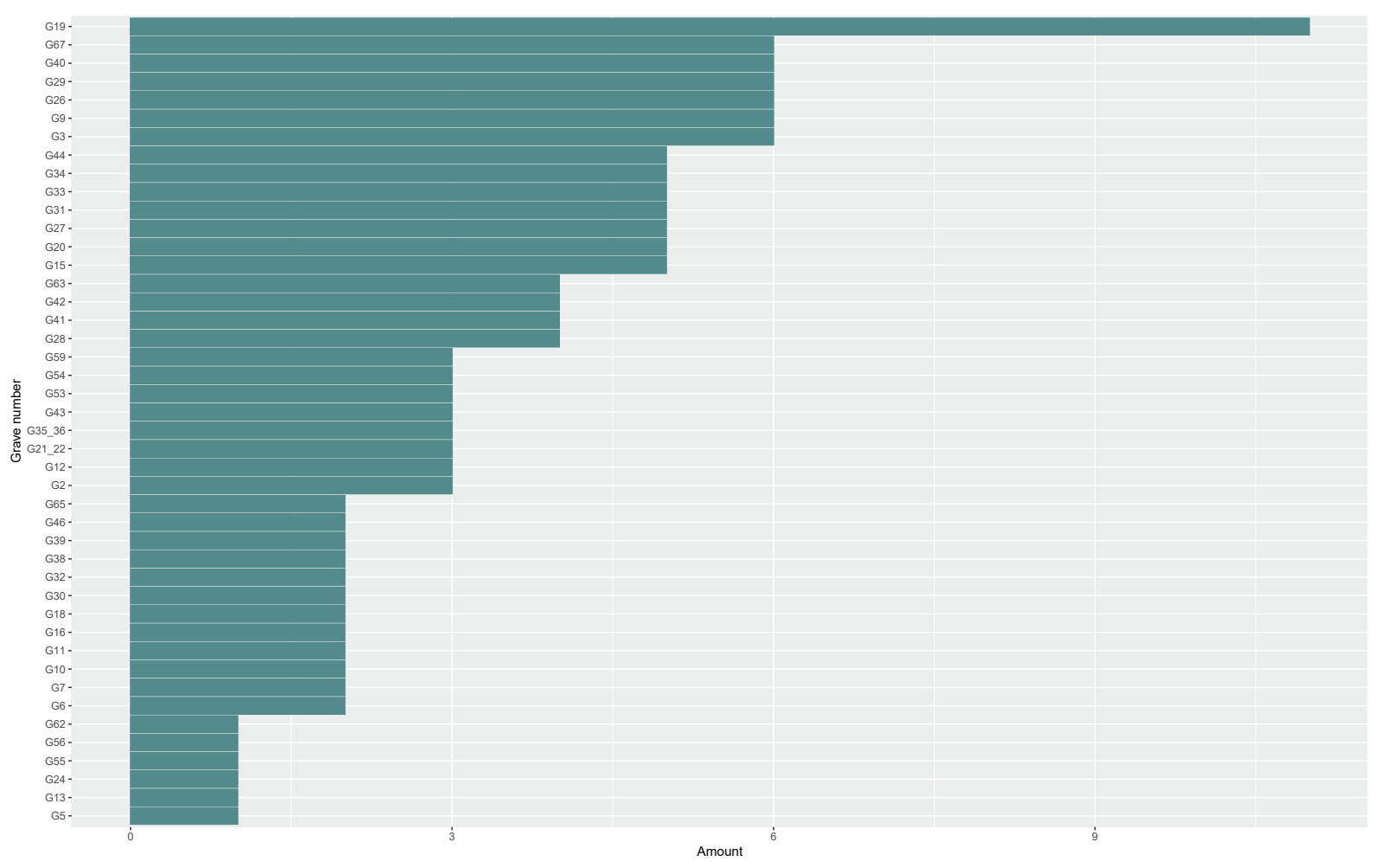

Fig. 2. The number of artifact types per graves in Szentlőrinc, without the empty graves.

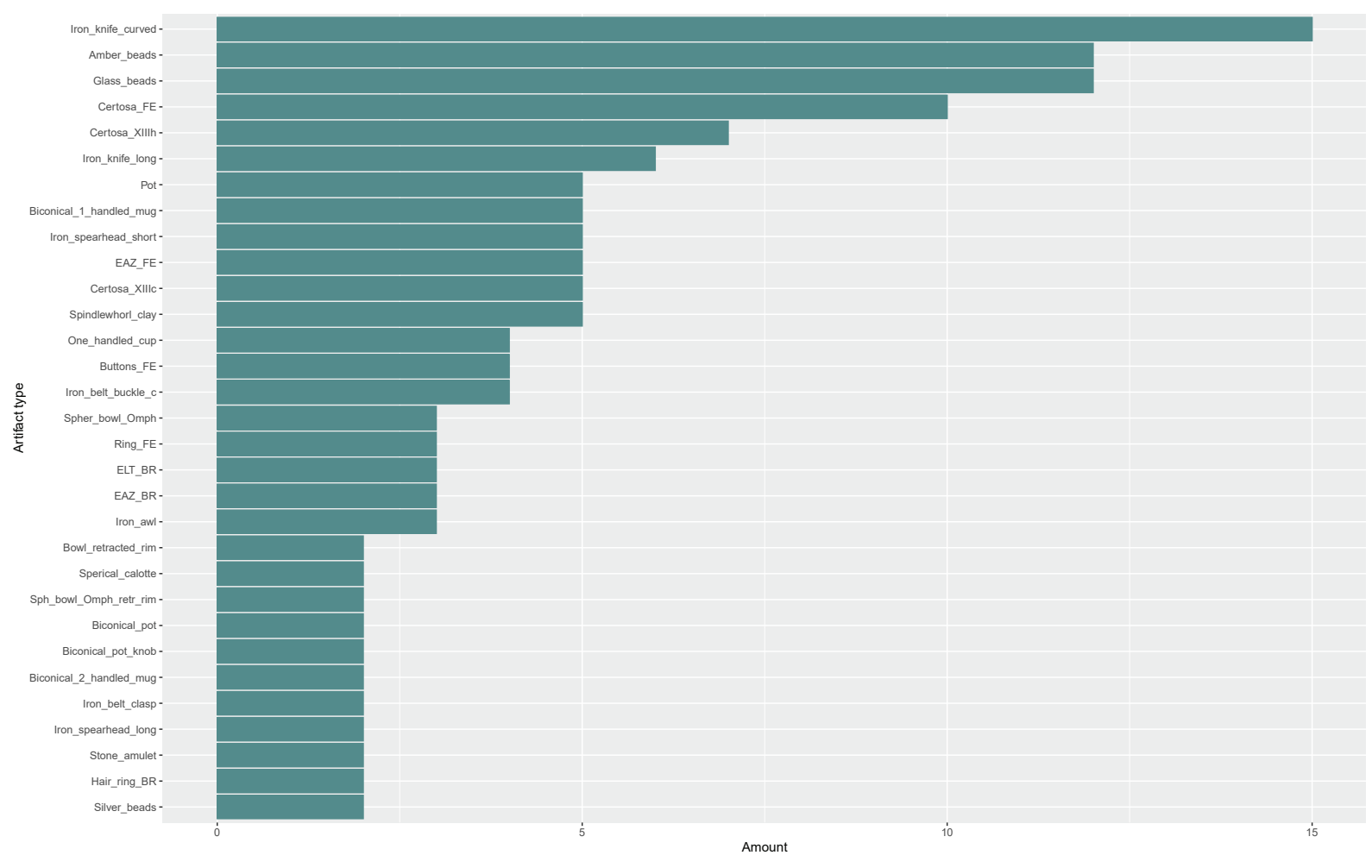

Fig. 3. Artifact types which occur more than once in Szentlőrinc 
also Fig. 4 shows, that the highest artifact variability in a grave is 6, apart from grave 19, containing 10 artifact types present more than once in the cemetery.

In the 36 furnished graves appear 133 artifacts (counted appearance per grave). Taking all 70 graves into account, the range $\left(\mathrm{x}_{\max }-\mathrm{x}_{\min }\right)$ of the artifact types is 11 , the median $2\left(\mathrm{x}_{0.5}\right)$, the mean 2.414286 and the variance 5.637474 (Fig. 5).

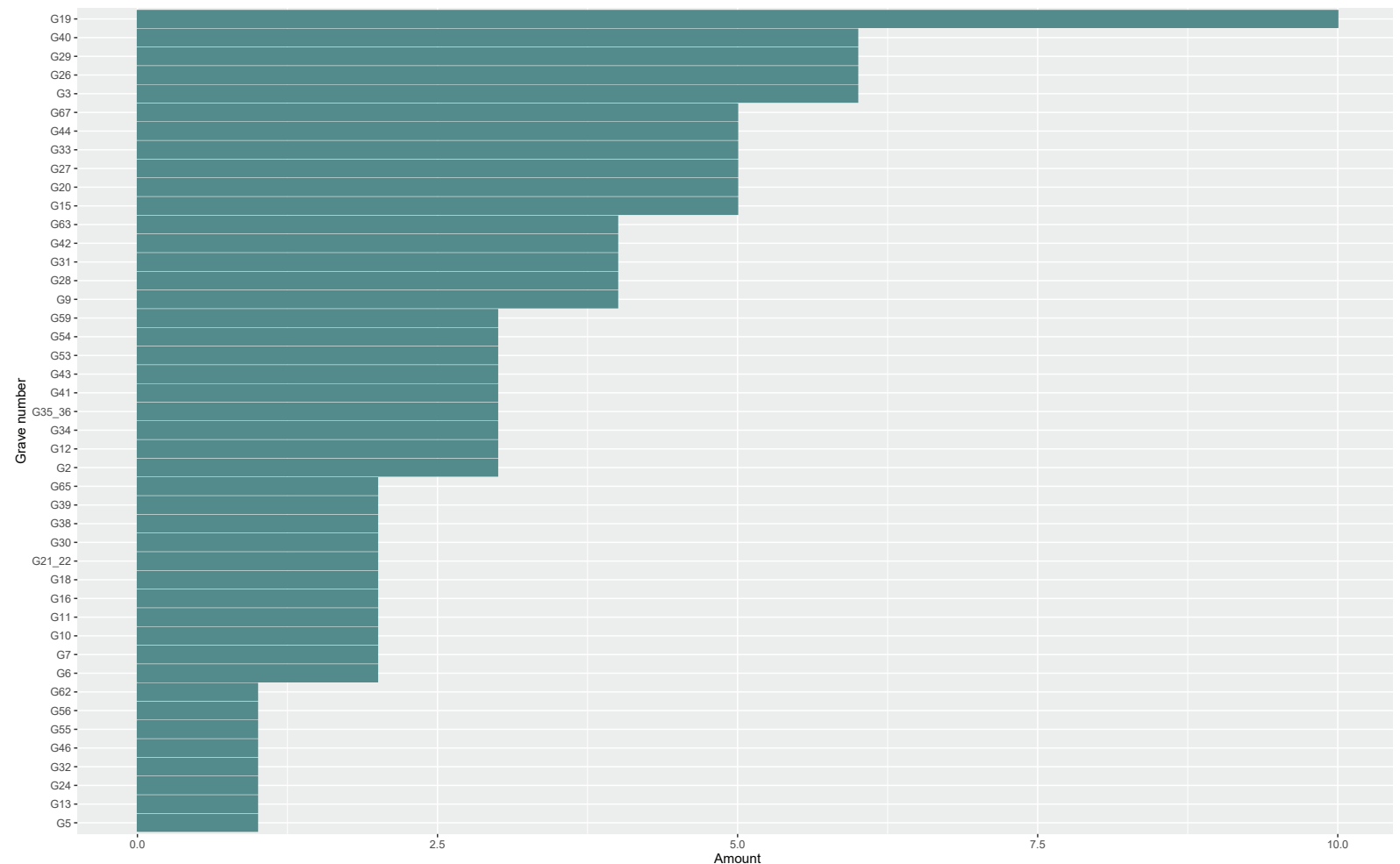

Fig. 4. The number of artifact types per grave present more than once in Szentlőrinc.

Understanding the overall nature of the data we are dealing with is important and to be able to do that, we have to test for the normal distribution of the data. To understand if the frequency of artifact types per grave is normally distributed we can use the Shapiro-Wilk and the Kolmogorov-Smirnov tests. The first statistical test is a test of normality, which Null-Hypothesis postulates, that the data is normally distributed. If the p-value is less than 0.05 , the usually set $\alpha$ level (in our case $5.845 \mathrm{e}-06=5,845 \times 10^{-6}=0,000005845$ ), then the Null-Hypothesis is rejected and it is the evidence of a not normal distribution. The Kolmogorov-Smirnov test is a non-parametric adjustment test that tells us if the data differs from a normal distribution. Additionally it can be used as a control of a parametric test, as in our case of the Shapiro-Wilk test. In contrast to the Shapiro-Wilk test the Kolmogorov-Smirnov test resulted in a p-value $=0.06931$, which suggests us that the data is normally distributed, though with a very little significance. A QQ-Plot, that is a probability plot gives us a better picture of the situation (Fig. 6).

We have to state that the Shapiro-Wilk test is more sensitive than the Kolmogorov-Smirnov test and thus shows the true nature of the data under investigation: that the frequency of artifact types per grave is indeed not quite normally distributed.

Looking at the depth of the graves, the absolute number of artifacts, the relative artifact quantity and the presence of the artifact types in the graves, we can say, that graves with high 
absolute artifact quantity (grave 52 with 62 artifacts, grave 67 with 57, grave 42 with 67) are not correlated to the grave depth, that is the presumption that deeper graves are possibly not disturbed and therefore might contain more artifacts can be dismissed (Fig. 7).

This empirical impression is supported by the Spearman's Rank Correlation Coefficient analysis (both the depth of the graves and the absolute artifact quantity are not normally distributed, based on the Shapiro-Wilk normality test - the depth of the graves resulted in

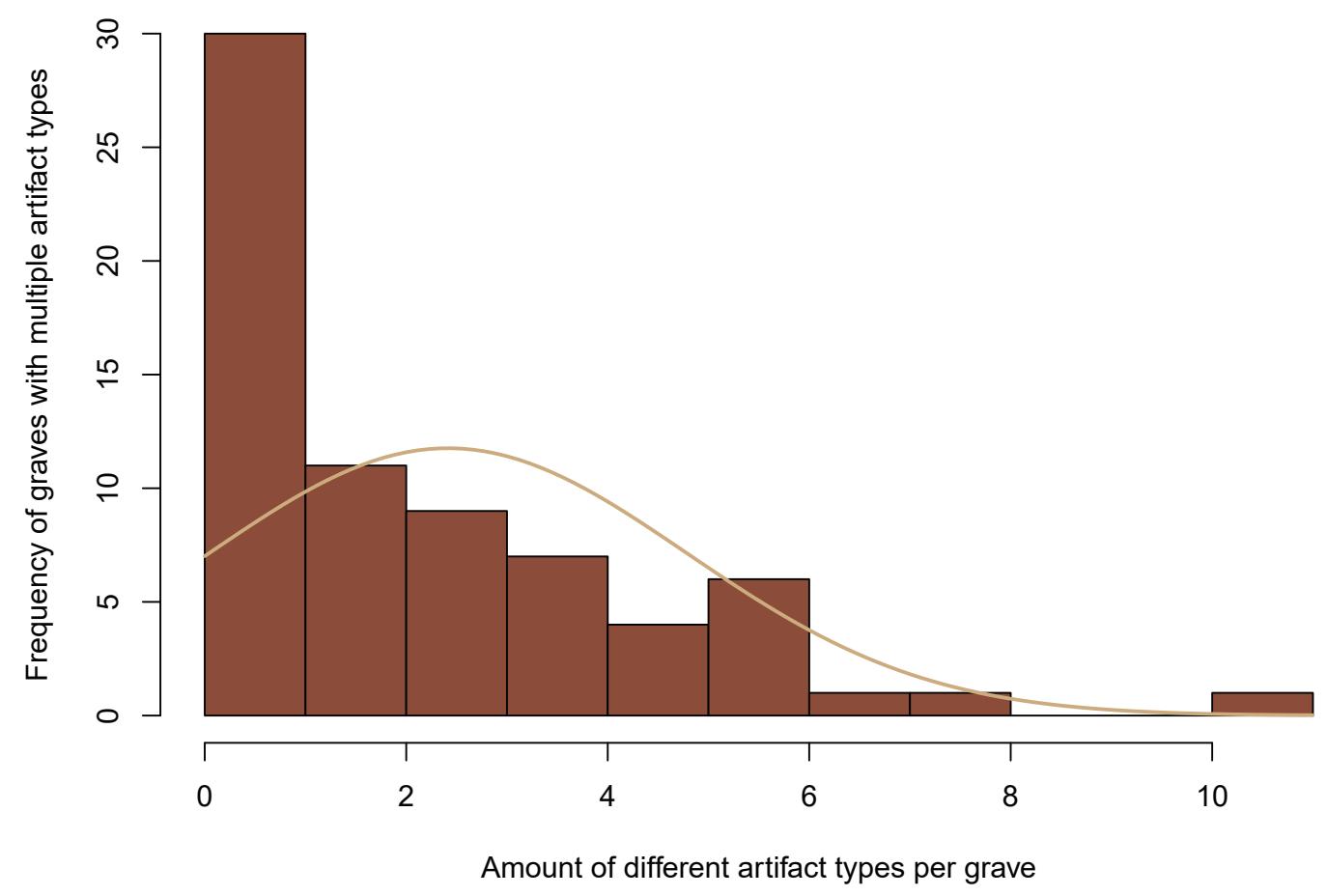

Fig. 5. The frequency of artifact types per grave in Szentlőrinc.

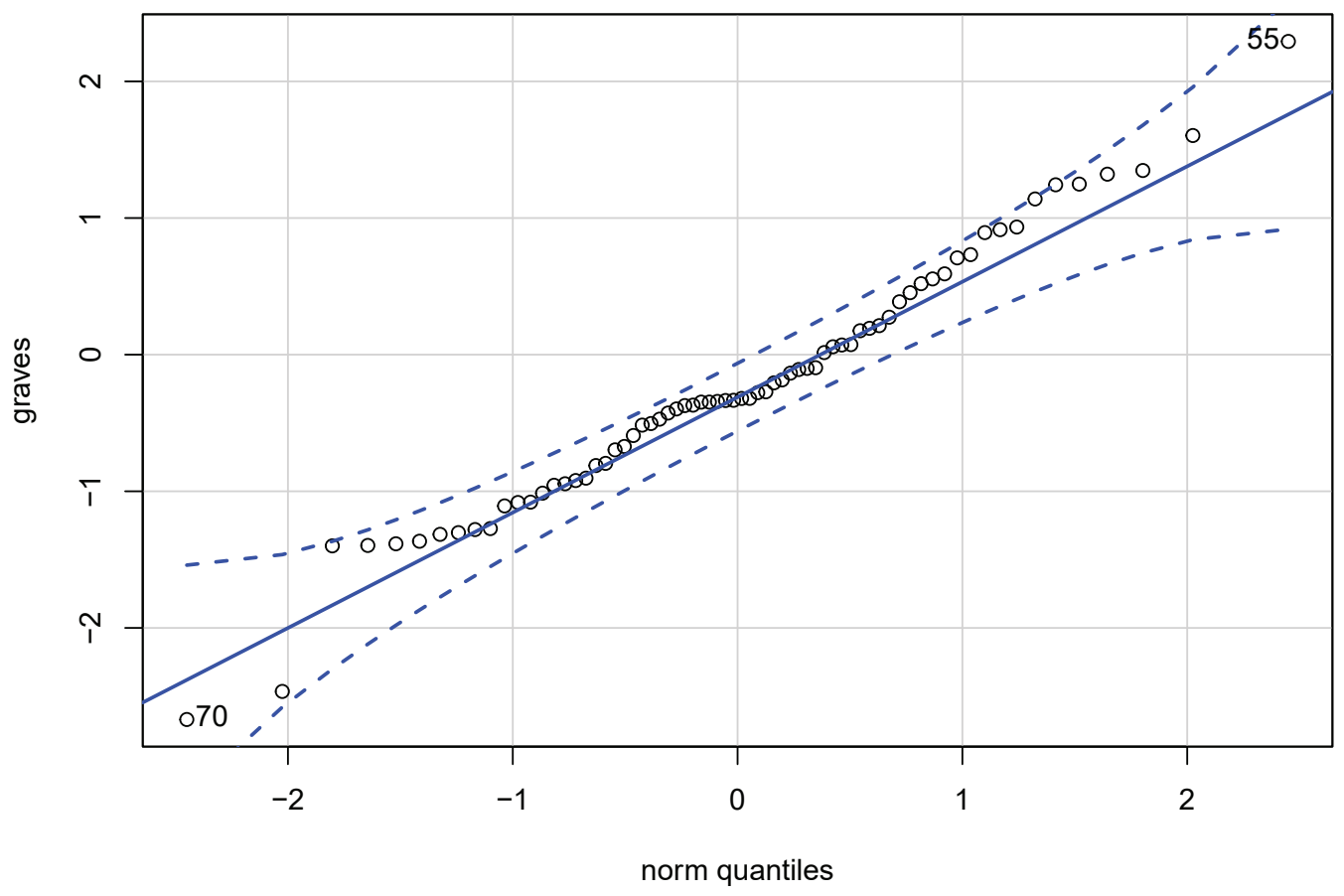

Fig. 6. A QQ-Plot of the distribution of the frequency of artifact types per grave in Szentlonrinc. 
$\mathrm{p}$-value $=0.000259$ and the absolute artifact quantity in $\mathrm{p}$-value $=2.079 \mathrm{e}-12$ ), which delivers a rho of 0.2023204 and translates into a significant weak correlation ${ }^{23}$ between the depth of the graves and the absolute quantity of grave goods in the graves ${ }^{24}$. This means that a deep grave does not automatically have a big number of grave goods and high absolute artifact quantity (the deepest graves do not contain any grave goods at all). Could the graves missing grave goods be partly due to (contemporaneous?) grave robbery and/or acid soil? The deepest grave is $100 \mathrm{~cm}$ and the median depth of the graves is $62 \mathrm{~cm}$.

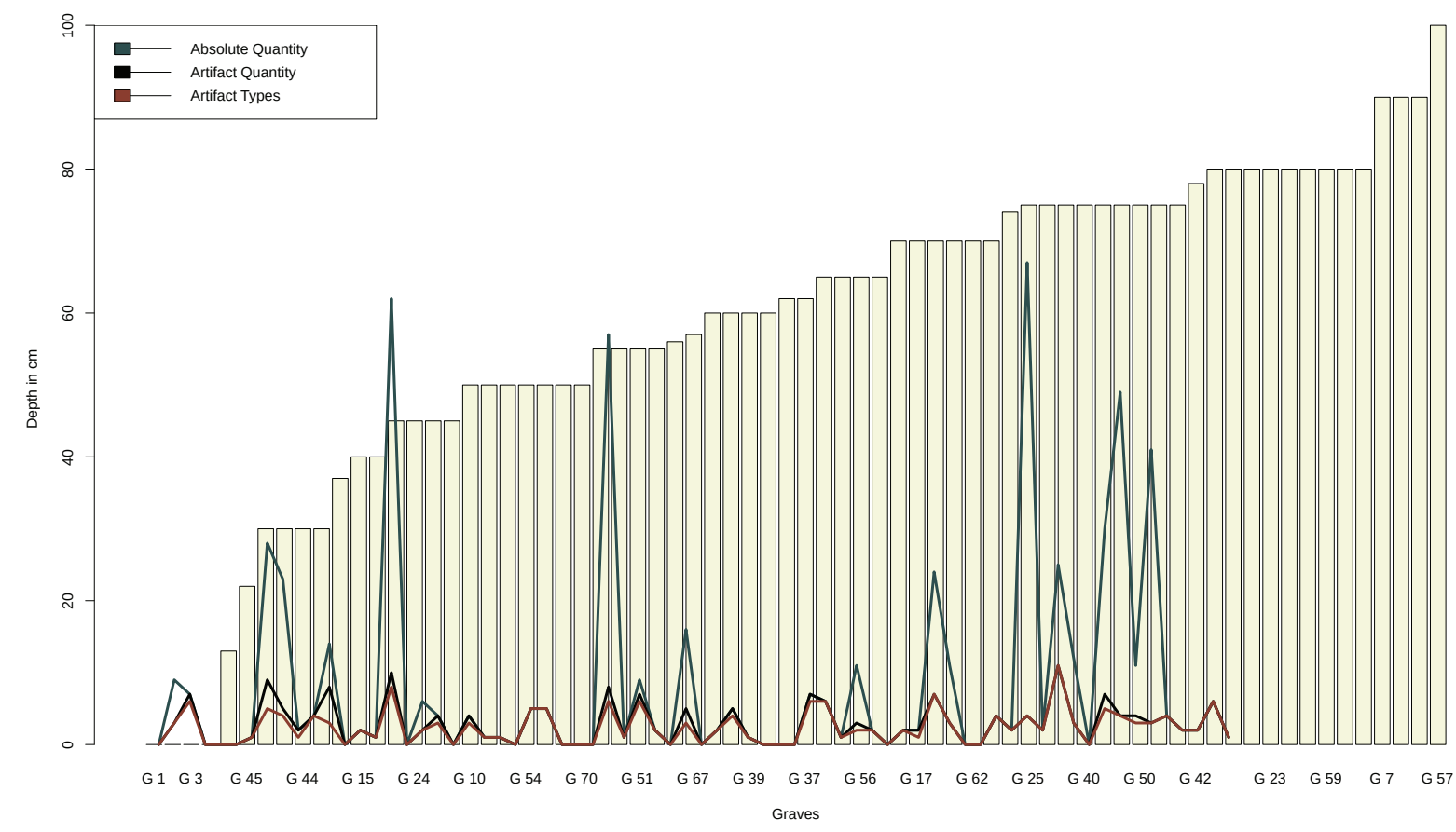

Fig. 7. Absolute and relative number and type of artifacts by grave opposed to the grave depth. Absolute Quantity: the quantity of every single artifact, including the number of beads; Artifact Quantity: the presence of all artifacts counted per grave - in the case of the presence of multiple beads they have been counted as 1, but multiple types of beads were counted separately; Artifact Types: only the number of artifact types are counted per grave, when multiple beads were present they have been counted as 1, but multiple types of beads were counted separately.

The gender of 58 individuals has been possible to determine, ${ }^{25}$ of which 34 are female $(7$ children) and 24 male (7 children). 17 graves have no orientations, from which 8 are cremations. This leaves us 55 graves with orientation and 58 graves with known sex. ${ }^{26}$ There are 5 double graves and 2 triple graves in the cemetery (from which 1 triple Horse burial). Because these graves yield cremation and inhumation or female and male burials at the same time, in certain cases they have been left out of the statistical analysis because they would deform the results. This reduces the data even more, even though the number of graves available for interpre-

The Spearman's correlation coefficient is a statistical measure of a relationship between two data sets. It is interpreted between $-1 \leq \mathrm{r} \leq 1$. The threshold lies between $.00-.19$ "very weak" and $.20-.39$ "weak" and so on. This means that 0.2023204 is more very weak than weak. http://www.statstutor.ac.uk/resources/uploaded/ spearmans.pdf

24 The depth of the graves and the absolute artifact quantity shows a very similar QQ-Plot, as figure 6. Thus we can count with a not quite normal distribution of the data set in any aspect.

26 JEREM 1968, 179. 


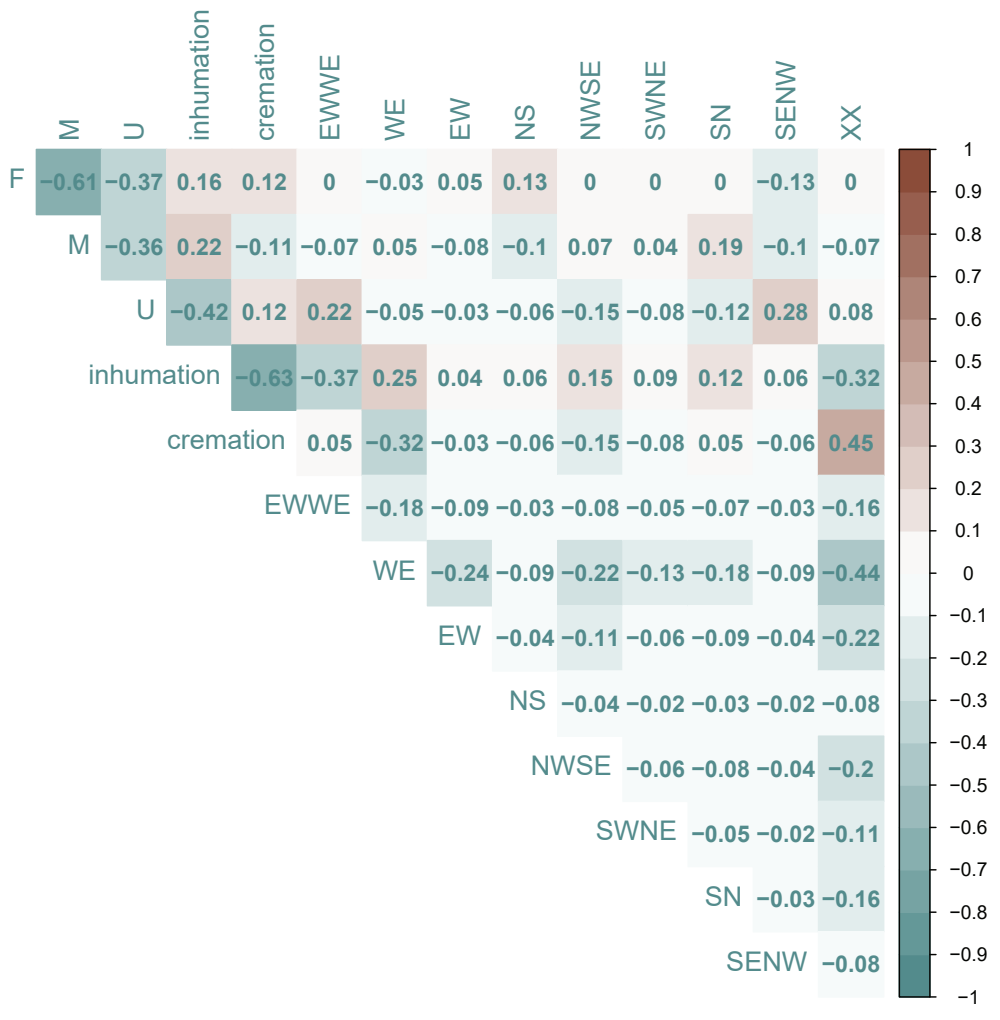

Fig. 8a. A correlogram of the gender, orientation and burial custom in Szentlőrinc with Spearman's Rho correlation coefficient. Encoding: F: female; M: male; U: unknown sex; XX: unknown orientation.

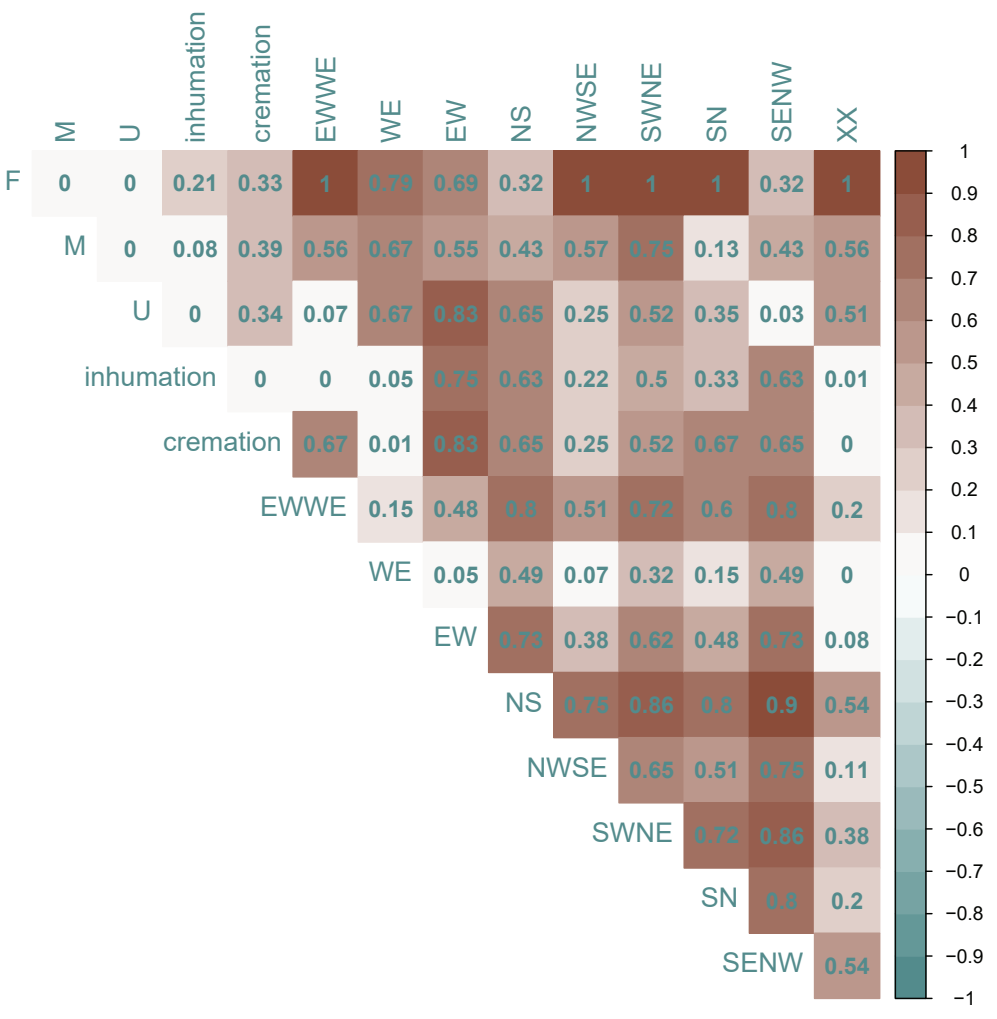

Fig. 8b. A correlogram of the gender, orientation and burial custom in Szentlörinc with the P significance levels for Spearman's Rho correlation coefficient. Encoding: F: female; M: male; U: unknown sex; XX: unknown orientation. 
tation is not that high as we saw (quite some graves lack grave goods). We are left with 50 graves with clear gender and 51 graves with orientation, which is not known of all gender-assigned graves and not all graves with orientation yield gender information.

To investigate possible relations between gender, orientation and burial custom, all graves (the multiple graves included) have been integrated in the correlogram (calculated with the Spearman's Rank correlation coefficient) because of the limited number of graves at our disposal (Figs $8 a, 8 b$ ). This makes the statistical result less clear (a grave being a male and female grave at the same time) but otherwise it would not be possible to compare the results to Figs 9, 10.

For an easier understanding the correlation coefficient on the diagonal (the self-correlation of our variables) has been hidden. The highest correlation coefficient is 0.45 between cremation and unknown orientation, which is self explanatory. The other positive, but not really significant correlations can be understood consulting Figs 9, 10. To understand the declaration of the correlograms, we have to bear in mind that the Spearman's correlation coefficient (Fig. 8a) measures the strength and the direction of a monotonic relationship between two variables (between -1 to +1 ). If the variables increase in the same direction the coefficient is positive, if they move in different directions, the coefficient is negative. It also has to be considered that a correlation does not have to imply causal relationship ${ }^{27}$ between variables because the relation of the data is by nature non-linear. The significance level (Fig. $8 b$ ) on the other hand tells us, if and how significant this result is, thus in this relation the H0 hypothesis $(\alpha \leqq 0.05)$ of the significance test postulates, that the correlation is significantly different from 0 between two variables and H1 $(\alpha>0.05)$ in contrary states, that the correlation is statistically not significantly different from 0 .

Altogether 9 orientation directions have been identified in Szentlörinc. We can translate the correlogram in numbers (excluding the burial custom):

\begin{tabular}{|c|c|c|c|c|c|c|c|c|c|}
\hline & $W-E$ & $E-W$ & $S-N$ & $N W-S E$ & $E W-W E$ & $S W-N E$ & $S E-N W$ & $N-S$ & $N E-S W$ \\
\hline Female & 10 & 4 & 2 & 3 & 2 & 1 & 0 & 1 & 0 \\
\hline Male & 9 & 2 & 3 & 3 & 1 & 1 & 0 & 0 & 0 \\
\hline$?$ & 3 & 1 & 0 & 0 & 2 & 0 & 1 & 0 & 0 \\
\hline Horse & 0 & 2 & 2 & 0 & 0 & 1 & 0 & 0 & 1 \\
\hline
\end{tabular}

Fig. 9. Orientation of the female, male and horse graves in Szentlörinc.

The result shows that there is some difference between the orientation of male and female graves. There are twice as much E-W directed female graves than male ones. There are 7 graves without known gender, if we consider the cemetery to be completely excavated, which could change the distribution. Depicting the data in Fig. 9 as a histogram we can emphasize even more that the $\mathrm{W}-\mathrm{E}$ orientation is the main orientation. $\mathrm{N}-\mathrm{S}$ oriented graves are of unknown gender and NE-SW oriented graves are female and SE-NW oriented graves are only horse graves (Fig. 10).

\section{A side note on Horse burials}

The orientation of the 6 horse burials is E-W (2 times), S-N (2 times) and NE-SW and SW-NE ( 1 each). They (graves $48,51,52,58,60,61$ ) contain - in regard to the bone material - exclu- 
sively the skull and the extremities. If we look at the horse burials of the neighboring Doljensko Group ${ }^{28}$ the deposition style of the horses shows a greater variability and the exclusive deposition of the skull and the extremities does not occur this clearly, though the majority of the horse burials contain bridles like in our case. The fact that only the skull and the extremities are displayed in the graves may point to the possibility that the meat of the animals was consumed as part of the funerary ritual.

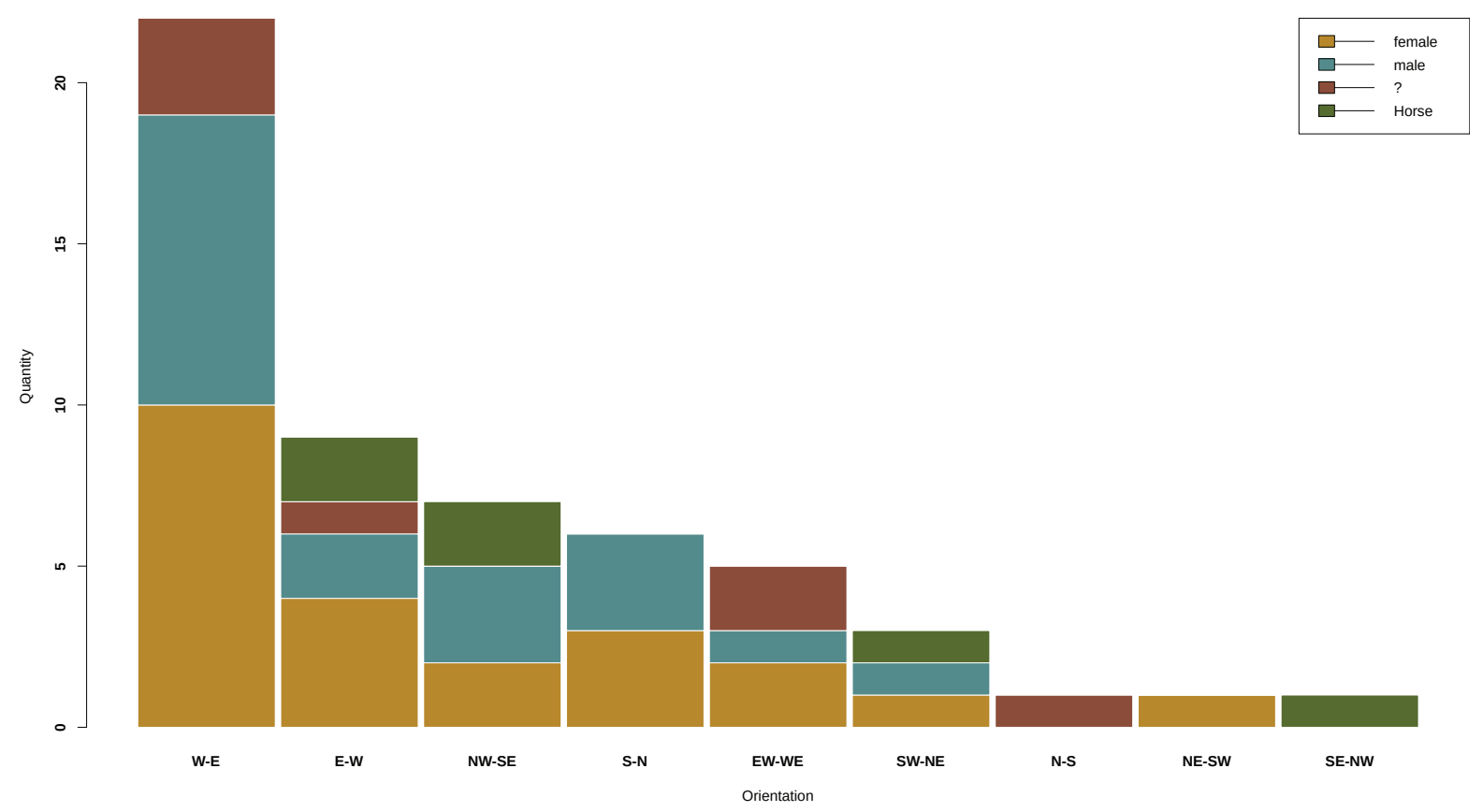

Fig. 10. Barplot of the orientation of the female, male, horse graves and graves without known gender in Szentlörinc.

The bridles from graves 52, 58, 60, 61 belong to the Type Szentes-Vekerzug. This type of bridle has already been investigated thoroughly by WERnER 1988, KEMENCZeI 2009 (missing the specimen from Szentlőrinc) and lately by Teleaga 2017. Teleaga 2017 classifies the bridles of type Szentes-Vekerzug in 3 (chronological) types on the basis of a Seriation and their association with horse harness related items. ${ }^{29}$ The specimens from Szentlörinc belong to the $2^{\text {nd }}$ (graves 52, 58, 60) and $3^{\text {rd }}$ (grave 61) types.

The $2^{\text {nd }}$ type can be dated to $525-450 \mathrm{BC}$ on the basis of parallels. ${ }^{30}$ Further, we have to reside with the bridle of the $3^{\text {rd }}$ type, because a chronological fixpoint is available to pinpoint the circulation time of this bridle type. That is to say a Teleaga Type 3 bridle is known from grave 3 , Tumulus 4 from Kandija in Novo Mesto for which grave a ${ }^{14} \mathrm{C}$ date is available: $2238 \pm 55 \mathrm{BP},{ }^{31}$ which has been translated roughly to the first half of the $4^{\text {th }}$ century BC. ${ }^{32}$ 


\begin{tabular}{|l|l|}
\hline KIA45221 & Horse tooth, apatite, $0.6 \mathrm{mg} \mathrm{C}$ \\
\hline Corrected pMC & $75.69 \pm 0.52$ \\
\hline$\delta 13 \mathrm{C}(\% 0)$ & $-10.75 \pm 0.06$ \\
\hline Conventional age & $2240 \pm 55 \mathrm{BP}$ \\
\hline Radiocarbon age & $2238 \pm 55 \mathrm{BP}$ \\
\hline
\end{tabular}

Fig. 11. The calibrated ${ }^{14} \mathrm{C}$ dates from Kandija, Novo Mesto, Tumulus 4, grave 3. After TeRžAN - ČEŠnAR 2014, 490 .

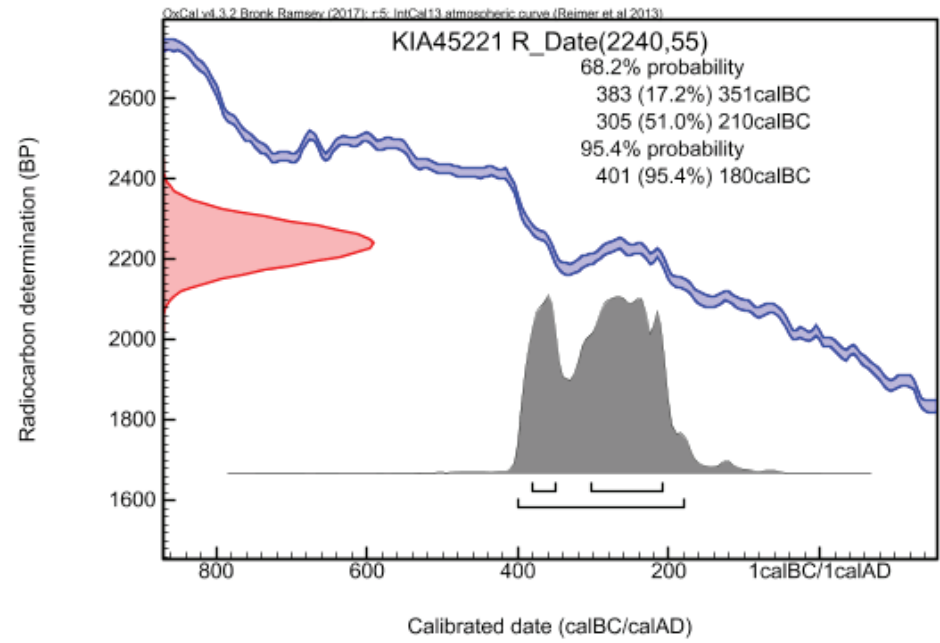

Fig. 12. The result of the radiocarbon analysis performed at the Leibniz Labor für Altersbestimmung und Isotopenforschung, Christian-Albrechts Universität Kiel. After TeRŽAN - ČEŠNAR 2014, 490.

This is a very important indirect absolute chronological indication for the chronology of Szentlörinc, although the horse graves form a more or less closed group in the southern part of the cemetery (apart from grave 52) and yield no other finds than the horse equipment and thus it is difficult to incorporate the horse burials in the structure (and the chronology) of the cemetery. ${ }^{33}$

What concerns the verification of the sources we have to stress, that there is a certain amount of graves which orientation is not known (Figs 9, 10). Also a fair amount of graves lack identifiable gender in which case we can only work with the archaeological gender, which is known not always to be very clear (on the basis of the grave goods). Thus there is missing information which we have to keep in mind when making assumptions.

\section{The fibulae}

The classification of the fibulae has been made on the basis of the descriptions and the drawings of the grave goods (Fig. 33). A deeper interest was given to the fibulae which were not corroded and show discernable, definitive features which can be used as classificatory elements. The corroded state of the iron fibulae does not make a very detailed interpretation possible, but they give us enough information to quiet our curiosity. In the case of certain details which are not visible from the published drawings, the author had to rely on the grave descriptions (for eg. the details of the corroded iron fibulae). The graves yield altogether 47 fibulae, from 
which 24 are bronze and 23 iron. Artifact 9.4, the spiral-fragment of a Crossbow-fibula, which cannot be classified more specifically has been left out from the consideration. Three main fibula types can be distinguished: Certosa fibulae, Eastern Alpine Zoomorphic fibulae (EAZF), and fibulae of the Early La Tène-Scheme (ELTS). The first two types are present in their iron and bronze variants, the latter only in bronze.

\section{The Certosa fibulae}

17 bronze and 17 iron fibulae can be defined as Certosa fibulae, more precisely as Crossbow Certosa fibulae of Types XIIIc, XIIIf, and XIIIh. ${ }^{34}$ Most of the iron fibulae are in a very bad condition - thus an accurate classification is in most cases almost impossible.

The Certosa Type XIII fibulae can chronologically be put in the late phase of the Certosa and the Negova Helmet horizon. ${ }^{35}$ The late XIII Types, like XIIIh, occur together with the Eastern Alpine Zoomorphic fibulae in the Negova helmet horizon. ${ }^{36}$ The absence of the Certosa Type XIII from the North-Eastern Hallstatt region in the Late-Hallstatt and Early La Tène Period points to the fact, that the main dispersion of the Certosa Type XIII lies in the southern Eastern Hallstatt region. ${ }^{37}$

Five fibulae can be assigned to the Type XIIIc in Szentlörinc, ${ }^{38}$ namely 3.2, 9.3, 15.1, 29.5 and 42.3. This fibula type exhibits a more "classical" Certosa foot than the Type XIIIh, that means that the knob on the foot is elevated on the continuation of the end of the catch-plate of the needle and not placed more to the interior as in the case of Type XIIIh. The bow of Type XIIIc presents a less angular, smoother profile than that of Type XIIIh. These characteristics of the two XIII subtypes make it difficult to classify the fibulae 3.2 and 15.1, which exhibit a more "classical" foot-knob and only the arc of the bow shows in the direction of Type XIIIh. The question is which typological element do we award more weight? For the foot-profile is a very specific element in fibula classification, these two specimens have been assigned to Type XIIIc, as has been 9.3.

Type XIIIf only occurs once in Szentlőrinc, with a very specific association, namely a Pannonian Kantharos. This Certosa type might be contemporaneous with the Type XIIIc, on the basis of their appearance together in grave 48 in Donja Dolina, from the field of M. Petrović Jr. ${ }^{39}$

Type XIIIh ${ }^{40}$ occurs in Szentlörinc separate from the fibulae of Early La Tène-Scheme, thus seem to precede those. The fibulae 2.2 and 44.3, though definitely belonging to the Crossbow Certosa fibulae of Type XIII, are hard to classify more precisely because the foot-end is missing. The arc of the bow presents itself less angular than Type XIIIh, but the quadrangular construction of the Crossbow and the application of nooses point into the direction of Type XIIIh.

Type XIIIf (21-22.1) and XIIIh $(2.2,44.3)$ show nooses or loops to attach pendants to the fibulae, although these pedants have not been found in the graves. Their closest parallels can be

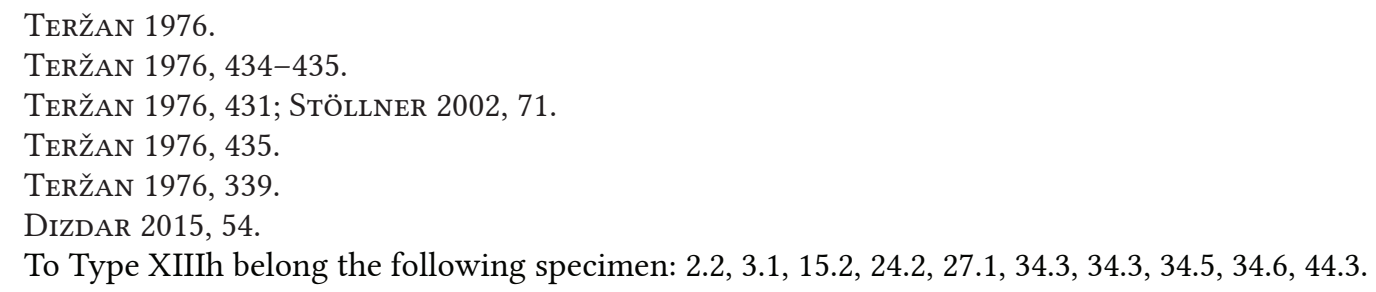


found in Sanki Most and Donja Dolina. ${ }^{41}$ About the Certosa Types XIIIh and XIIIc can be said that they were at least partly temporary, as shown by their distribution and association in Szentlörinc: they occur together in graves 3 and 15 and with bronze Eastern Alpine Zoomorphic fibulae in grave 27 (Type XIIIh), 29 and 42 (Type XIIIc).

Iron Certosa fibulae ${ }^{42}$ with bent back feet are considered as imitations of Eastern Alpine zoomorphic fibulae. ${ }^{43}$ As already pointed out, these could not be classified more thoroughly due to their state, thus only their association is investigated. They appear as sole fibula type in graves 19, 35-36, 39, 59 and 67, three times with iron Eastern Alpine Zoomorphic fibulae in graves 29, 33, 43, twice with bronze Certosa Types XIIIc and XIIh in grave 15 and with Type XIIIh in grave 29 and once with bronze Early La Tène-Scheme fibula in grave 40.

\section{The Eastern Alpine Zoomorphic fibulae}

Eastern Alpine Zoomorphic fibulae (EAZF) ${ }^{44}$ correspond to the Crossbow-fibulae of Certosa type with foot ending in the stylised animal head in the original publication ${ }^{45}$ and as such are closely related to the Certosa fibulae Type XIII. ${ }^{46}$ As already pointed out, bronze Eastern Alpine Zoomorphic fibulae appear with Type XIIIh in grave 27 and Type XIIIc in grave 42 or solitarily (grave 41). Iron Eastern Alpine Zoomorphic fibulae on the other hand appear either with Iron Certosa fibula or bronze Early La Tène-Scheme fibulae.

\section{The Early La Tène-Scheme fibulae}

Early La Tène-Scheme fibulae (ELTSF) or also called Birdhead fibulae ${ }^{47}$ depicting waterbird-heads connect in their form to the urnfield - Hallstatt visual world. Specimens of this type have only been found in its bronze version in Szentlörinc and appear together with either Iron Certosa fibula or Iron Eastern Alpine Zoomorphic fibulae (in both cases only once).

\section{The spatial distribution of the fibulae in Szentlörinc}

On the basis of the mapping of the fibulae in the cemetery (Fig. 33) we can conclusively say, that bronze Certosa fibulae (Types XIIIc, XIIIf, and XIIIh) have been deposited in the N part of the cemetery (grave 44 being the most southern grave to contain bronze Certosa type fibula). Iron Certosa fibulae occur opposed to that in the $S$ part of the cemetery (apart from grave 19 in the N), along with bronze Early La Tène-Scheme fibulae and bronze Eastern Alpine Zoomorphic fibulae. Iron and bronze Certosa Types occur only in grave 15 and 29 together. Bronze Early La Tène-Scheme fibulae are on the other hand associated with iron Certosa and iron Eastern Alpine Zoomorphic fibulae. The co-occurrence of the different fibula types results as follows:

42 The following Iron Certosa fibulae are present in Szentlörinc: 15.3, 15.4, 19.11, 29.7, 33.1, 33.2, 35-36.3, 35-36.4, 39.1, 40.4, 43.2, 59.2, 59.3, 67.4, 67.6, 67.7, 67.8.

43 DizDAR 2015, 54.

44 To this type belong the following specimen: from bronze: 27.2, 41.2, 42.4, from iron: 29.3, 29.4, 33.3, 43.3, 63.7.

45 JEREM 1968, $161 \mathrm{ff}$.

46 StÖLlnER 2002, 650.

47 JEREM 1968; STÖLLNER 2002, 66. 


\begin{tabular}{|l|l|l|l|l|l|l|l|l|}
\hline & XIIIc & XIIIf & XIIIh & Certosa & EAZ (BR) & EAZ (FE) & ELTSF & $\Sigma$ \\
\hline XIIIc & 5 & & 2 & 1 & 1 & 1 & & 5 \\
\hline XIIIf & & 1 & & & & & & 0 \\
\hline XIIIh & 2 & & 10 & 1 & 1 & & & 4 \\
\hline Certosa & 2 & & 1 & 17 & 1 & 3 & & 7 \\
\hline EAZF (BR) & 1 & & 1 & & 3 & 0 & & 2 \\
\hline EAZF (FE) & 1 & & & 3 & & 5 & 1 & 5 \\
\hline ELTSF & & & & 1 & & 1 & 2 & 2 \\
\hline
\end{tabular}

Fig. 13. The co-occurence of fibulae types in Szentlörinc. The diagonal depicts the absolute occurrence of the fibulae types. The number on the right $(\Sigma)$ shows how many times the fibula type occurs in association of other fibula types.

In the following the fibulae are investigated separately, because they are distributed quite evenly in Szentlörinc, (apart from the graves without grave goods) so they can give us a strong hint about the development and the duration of use of the cemetery. The Certosa Type XIIIf has been left out, because it occurs only in 1 grave in the whole cemetery, and it would distort the Correspondence Analysis in means of forming an outlier. The biplot of the combination of the fibulae on the basis of their co-occurrence looks as follows:

The Correspondence Analysis displays the so-called Guttman-Effekt (or Horseshoe-Effect), although in a bit distorted form. Still it is visible that there is a strong link between the graves - in archaeological analysis this factor is often assumed to be time. We can see in the biplot that graves 29, 15 and 27 distort the horseshoe-shape. The association of the fibulae makes us understand why: grave 41 only contains bronze Eastern Alpine Zoomorphic fibulae and grave 3 Certosa Types XIIIc and XIIIh. Graves 42 and 27 contain bronze Eastern Alpine Zoomorphic fibulae and a bronze Certosa XIII Type fibula.

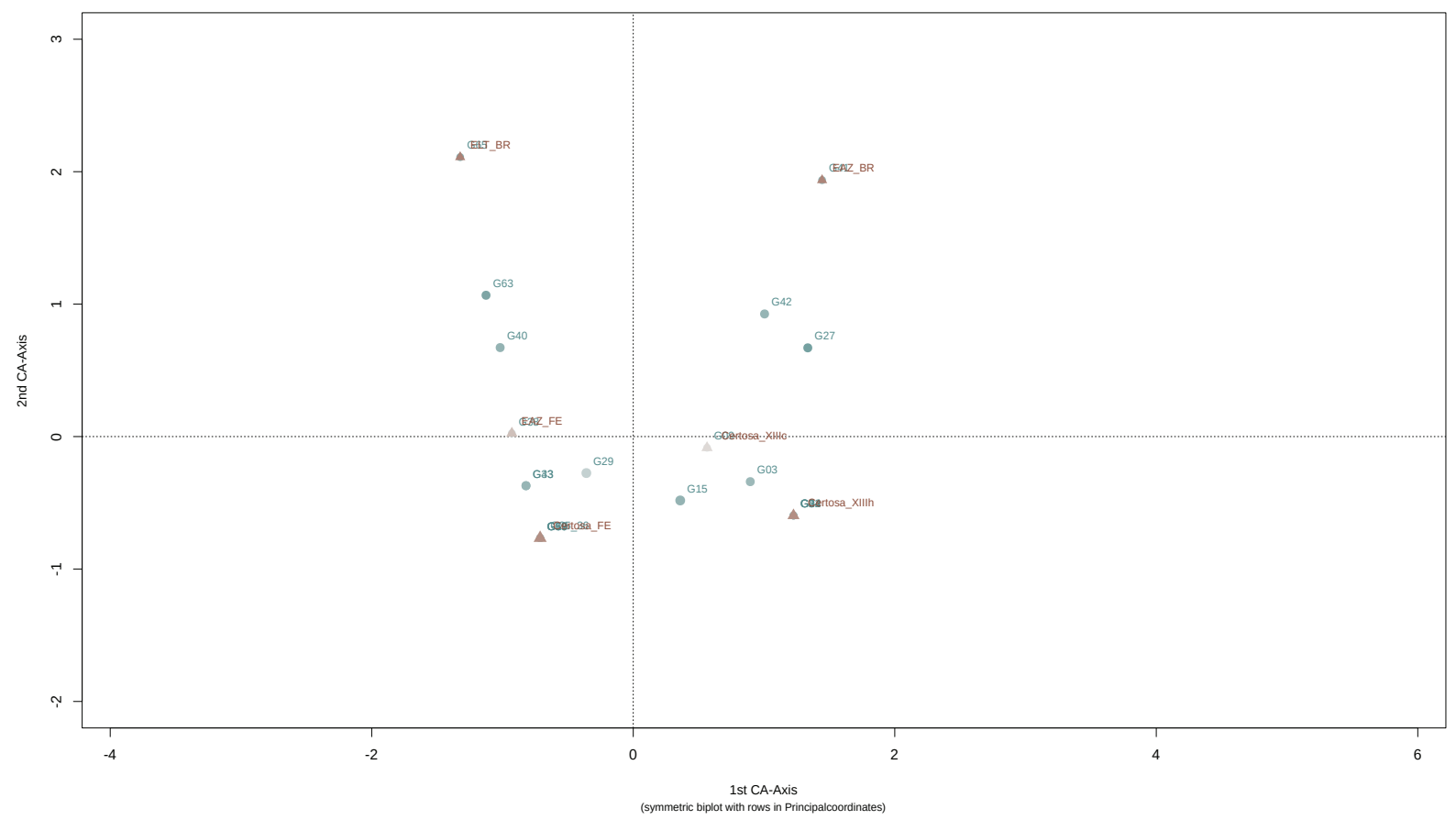

Fig. 14. Biplot of the Correspondence Analysis of the fibulae in Szentlőrinc. 
Graves 29 and 15 contain three different fibulae types and graves 39, 59, 67, 19 and 9, 2, 24, 34, 44 all contain one fibula, which normally would make them to be left out of any multivariate analysis, but in the case of Szentlonrinc we do not have much data and thus we inlude them. Two main groups are discernible in the biplot (Group B on the left and Group A on the right see the details further on). Graves 15 and 29 seem to form a "bridge" between the two groups, containing fibulae from both groups (see later the Seriation: Figs 17, 18). These two groups are confirmed by the Cluster Analysis (in form of a Cluster Dendrogram ) (Fig. 15).

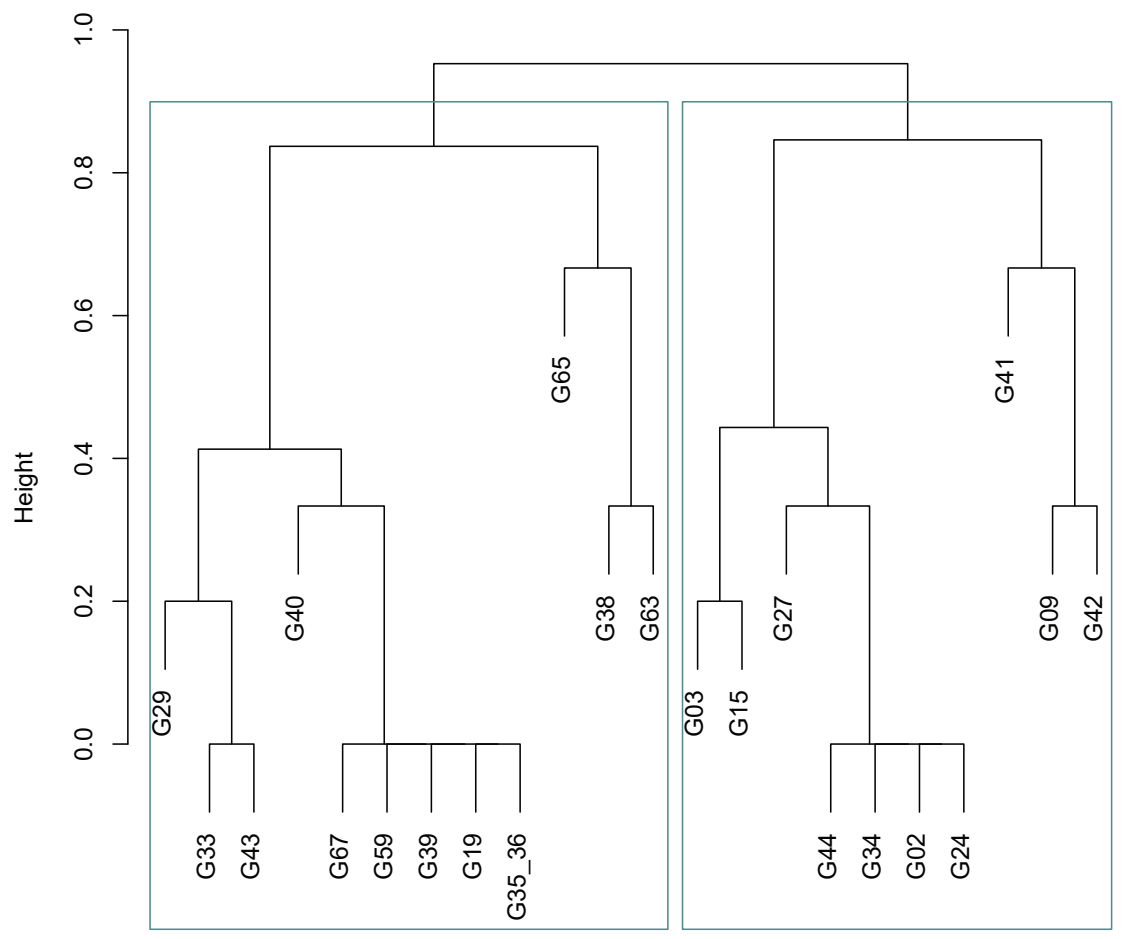

Fig. 15. Cluster Dendrogram of the fibulae in Szentlőrinc

To cross-check the predication of the Cluster Analysis, we can overlay a classification on the Correspondence Analysis. In means of adding the numbers of clusters to the biplot, we can test and validate the groups of the artifacts (Fig. 16).

If we compare the result of the Cluster Analysis with the distribution of the fibulae in the cemetery (Fig. 33) it is visible, that the right group actually corresponds to the already noticed distribution of the bronze Certosa types and the bronze Eastern Alpine Zoomorphic fibulae, with it's "southernmost" occurrence in grave 41. The left group with the iron Certosa fibulae at the core constrain themselves to mainly the southern part of the cemetery, having graves 15 and 29 as "gateway", containing three types of fibulae. The resulting relative sequence of the fibulae types is resonating the result of the Seriation of Th. Stöllner: the bronze Eastern Alpine Zoomorphic fibulae never occurs together with bronze Early La Tène-Scheme fibulae, ${ }^{48}$ but an iron Eastern Alpine Zoomorphic fibula does (see grave 63), at least in Szentlőrinc.

Focusing on the sequence of the fibulae types it is clear, that graves 40, 63 and 65 are 'closing' the cemetery - containing Early La Tène-Scheme fibulae and also holding a position at the top left corner of the left group of the CA, overlayed by the Clustering (Fig. 16). To understand and 


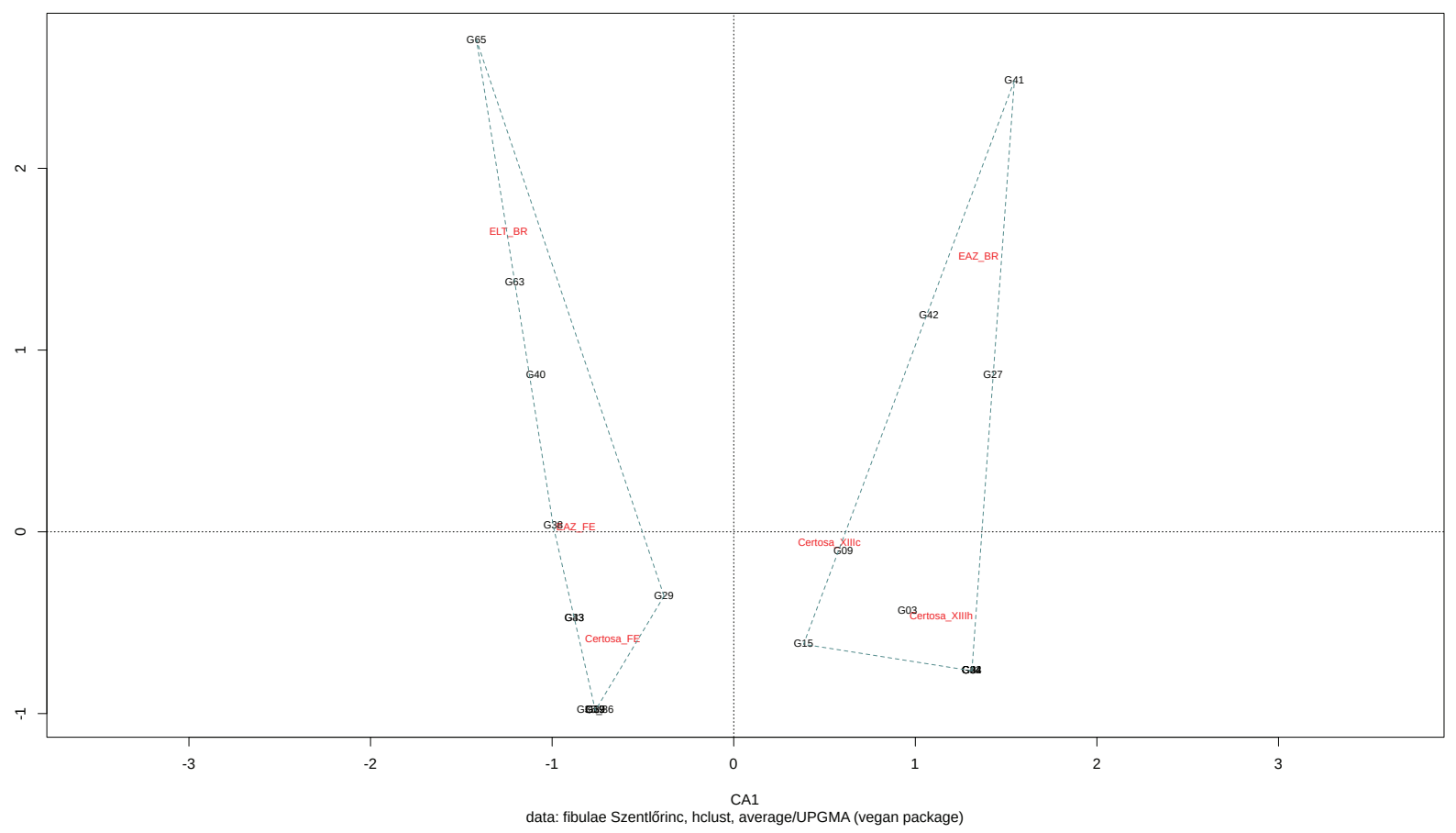

Fig. 16. Biplot of the CA of the fibulae in Szentlőrinc overlaid by clusters

explore the sequence of the fibulae more in depth, a Seriation (that is the $1^{\text {st }}$ Axis of the CA $)^{49}$, combined with a Cluster Dendrogram can give us more information (Fig. 17). The combined analysis points out very nicely further different subgroups. On the left we can see the Cluster Dendrogram of the subgroups of the artifacts (on the basis of their co-appearance) and on the top the Cluster Dendrogram the groupings of the graves.

The grouping of the graves (the clusters on the top) reflects the two main groups of the Cluster Analysis, separating the cemetery roughly in three areas: an Northern (A) and a Southern/ Center (B) region, as well as an area C, geographically located in the Eastern area of the cemetery (Figs 18, 33). Group A is not very easy to subdivide, because the bronze Eastern Alpine Zoomorphic fibulae occur with two other, different fibulae types thus dispersing in the group. This points to the fact, that bronze Eastern Alpine Zoomorphic fibulae, Certosa Types XIIIh and XIIIc (and probably XIIIf) are contemporaneous and are then replaced by iron Certosa fibulae and iron Eastern Alpine Zoomorphic fibulae, thus showing a tendency from bronze to iron fibula types, even if the Early La Tène-Scheme fibulae are of bronze. Group A suggests that the time-span reflected in the cemetery is not very broad.

We have to point out altogether three graves (highlighted in dashed boxes in Fig. 16). Graves 15 and 29 already stood out in the Correspondence Analysis - here we can add grave 40, which also contains multiple fibula types and form so to speak links between the different factions in the cemetery.

This all raises the question: what does the clustering of the fibulae show? Does it show chronological or social clusters, also geographically discernible in the cemetery (Fig. 33)?

49 The visualization of the Seriation is due to the vegan package settings, which is reverse than how we would normally 'read' a Seriation. 


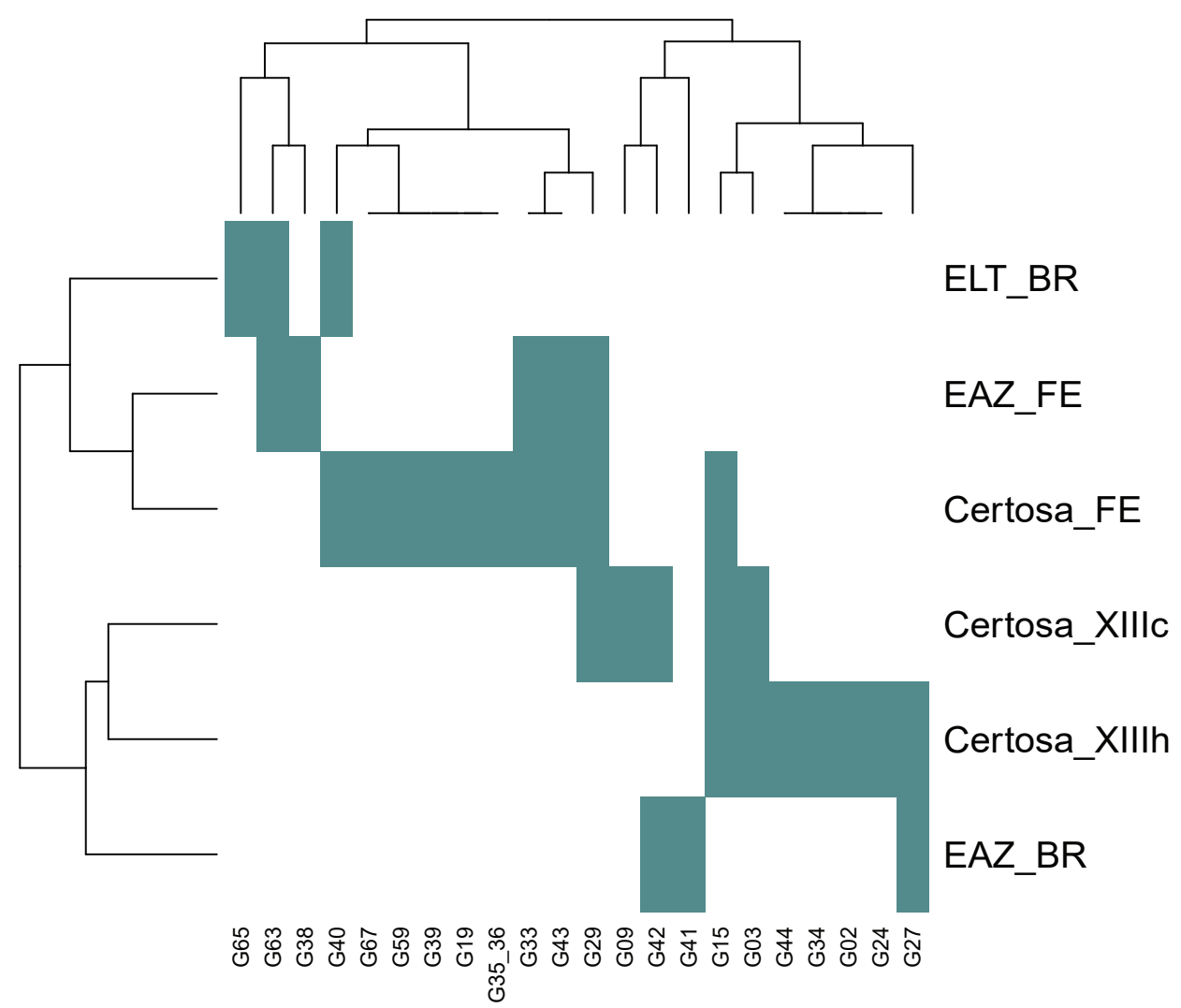

Fig. 17. Seriation combined with a Cluster Dendrogram of the fibulae in Szentlőrinc.

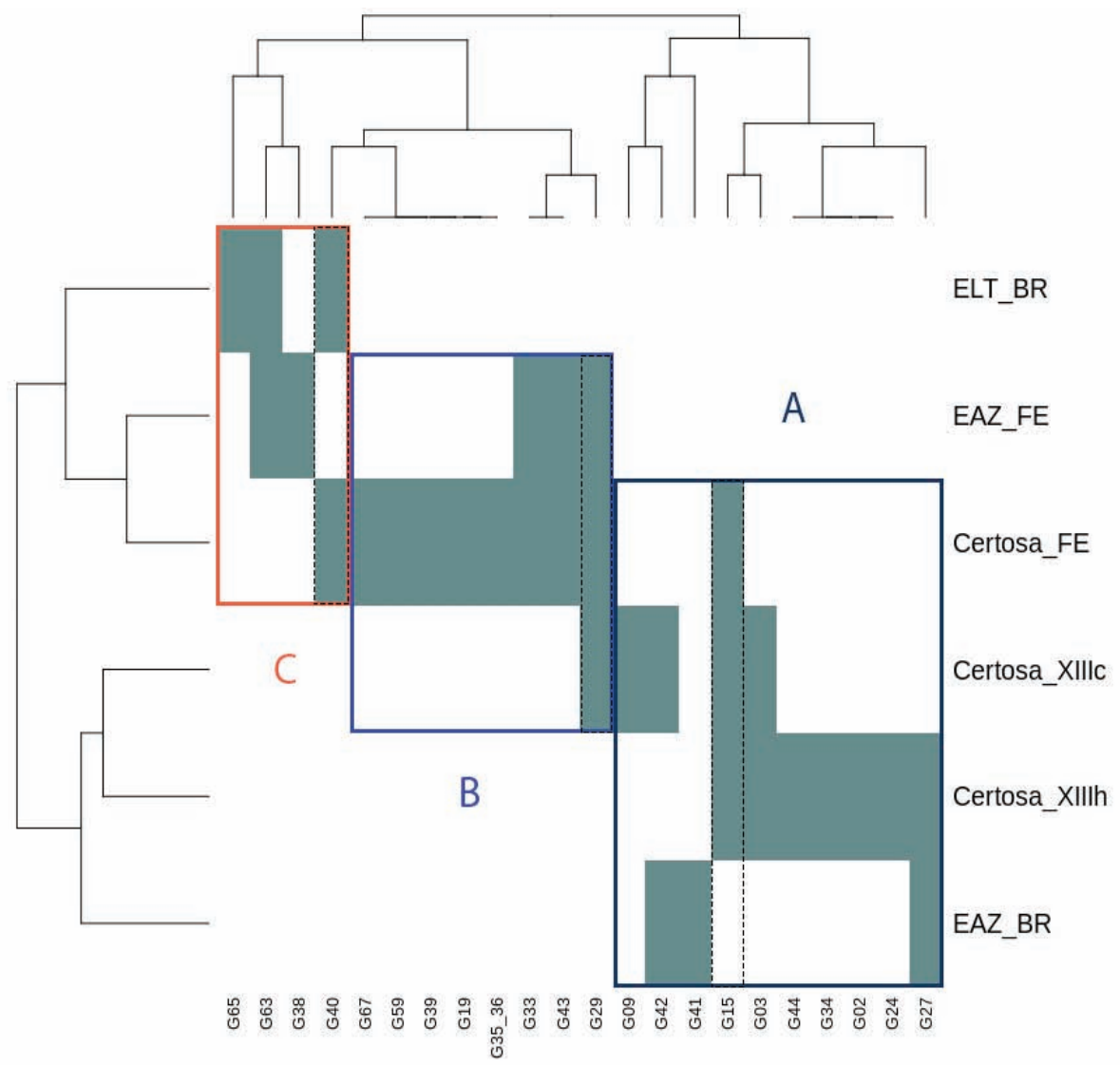

Fig. 18. Interpretation of the Seriation combined with a Cluster Dendrogram of the fibulae. 
In the case of the fibulae all (previously described) multivariate analyses have been conducted, shown and discussed. It can be seen that all of them highlight a bit different traits of the data set. To keep the study short, in the following only the most expressive analysis will be displayed and discussed. At this point we have to underline that 18 out of 72 graves $(25 \%)$ had no grave goods, and even more graves are in bad condition, which means that we do not know about the nature of the missing grave goods. With other words all artifact groups or chronological phases in the cemetery have more or less $75 \%$ probability.

\section{The pottery}

The pottery has typologically been classified on the basis of the drawings and the grave descriptions in the publication (Fig. 34). ${ }^{50}$ Smaller fragments and vessels, which profile was not preserved and thus was not enough to assign to a specific type, were left out from the consideration: e. g. $40.8,54.4,57.1,63.2$, the pottery shards over grave $63,67.10,67.11,68.1$ and the stray finds. First of all we have to accentuate, that all pottery was handmade..$^{51}$ This is reflected in the ceramic material of Sopron-Krautacker: the wheel-made ware was only introduced with the evolved LTA phase and the development of the profiles shows an overall tendency from sharp to curved profiles (Sopron-Krautacker IVb). ${ }^{52}$ From a typo-chronological point of view it must be said, that it is not easy to analyze and classify the ceramic assemblage of Szentlörinc, for the handmade forms are by design quite individual ${ }^{53}$ and there are very few specimen per type and altogether the number of vessels in the cemetery is not that high. The pottery forms (Figs 18, 34) belong to Horizon V of C. Metzner-Nebelsick, which corresponds to the Certosa and the Negova Horizons. ${ }^{54}$ Szentlörinc shows already at first glance diverse connections: the one-handled mugs connect to the Szentes-Vekerzug-Type cemeteries in the Alföld (as the lead-find form of that region) and the Pannonian Kantharoi to the Srem group.

Altogether 12 different pottery types could be defined. In the following certain forms are addressed separately.

Pots are present in 3 main forms: in biconical variety, biconical with knob handle and as eggor elongated form often with the rim broken down. Pots with knob handles are characteristic for the late Early Iron Age. ${ }^{55}$

The one-handled cup from grave 20 (20.2) shows strong similarities with the Type A cups defined by TANkó 2005, only with broken handle decoration, ${ }^{56}$ which could have been a disc $^{57}$ or a double knob-handle (handle variant e) according to the classification of TANKó 2005. One-handled cups with handle decoration occur already from $\mathrm{Ha} \mathrm{C}$ but this type of setting is in circulation until LTB. On the basis of this classification, its form and profile can be put typological earlier as the biconical one-handled cups in the cemetery, all without a horn-handle. On the basis of the typo chronology of TANкó 2005 and DoBIat 1980, the one handled-cup from grave 20.2 could be dated to $\mathrm{Ha}$ C2/D2, 650-550 BC, which corresponds

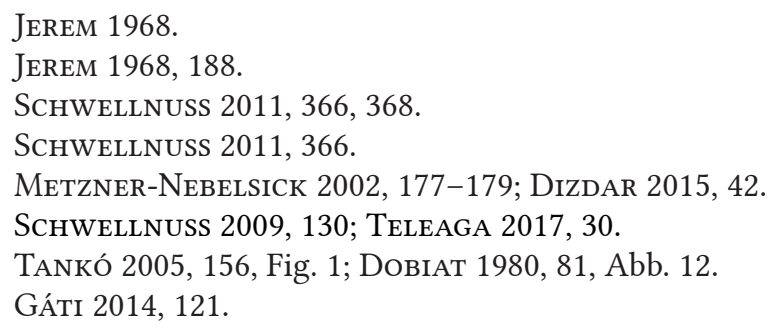


to Keramik-Horizont IV of C. Metzler-Nebelsick and the biconical one-handled mugs, without horn-handles can be attributed as Type B cups, thus to the successive period, HaD2-D3. ${ }^{58}$ Apart from 20.2 three other specimens can be found in the cemetery, though less elaborate and without horned handles. According to the distribution map of TANkó 2005 Type A spread along the Amber road, that is along the water-routes in Transdanubia, under strong Scythian influence and Type B can be attributed to the south-eastern Alpine group of the Eastern Hallstatt culture. Thus we seem to have two successive types in the same cemetery, but if we map the distribution of the one-handled cups and the biconical one-handled cups in Szentlőrinc it is visible that grave 20 contain both forms. The presence of Type A cup together with Type B cup shows the complex nature of the cemetery of Szentlonrinc very precisely. Probably it is not far from the truth, that the one-handled cup from grave 20.2 is a long-lived form or a revival of the form. Gáti brings the one-handled cup in connection with flat disc-like handle-decoration (Type 5), ${ }^{59}$ which decoration in our case is broken off. For a clearer answer a more thorough research and more specimens are needed. Overall we can say about the biconical one-handled cups, that the profile develops from the hard contours to the smoother, S-Profile direction, like the specimen in grave 63 (63.1). The broken "zoomorphic handle", Type 1 after GÁti 2014 from grave 46 was probably applied to a vessel and did not belong to a (horned-handled) cup.

There are two specimens of the so-called "Pannonian Kantharoi" in Szentlörinc, namely from grave 13(.1) and 21-22(.3). Both graves have a similar orientation (although grave 21-22 being a double female grave). The two specimen from Szentlőrinc show very close connection to kantharoi for eg. from Szajk, ${ }^{60}$ where kantharoi "are present in the assemblages of almost all the excavated features" ${ }^{61}$ and Zvonimirovo. ${ }^{62}$ This vessel type can be attributed to the south Pannonian ceramic tradition in Smyrnia, Slavonia and Baranja between the $6^{\text {th }}$ to the $4^{\text {th }}$ centuries BC, in other words to the Srem group. ${ }^{63}$ In addition, also the bowls and calottes can be considered as the continuation of Early Iron Age ceramic traditions. ${ }^{64} \mathrm{M}$. Dizdar was able to elaborate, that in the south Pannonian region the handmade Kantharoi, bowls and cups continued to exist at least until the Middle-Latène period and stand for a surviving autochthonous ceramic tradition, up to at least until the $2^{\text {nd }}$ century BC (on the basis of the archaeological material of Zvonimirovo). ${ }^{65}$

Other ceramic forms also show connections to the first/early phase of Szajk: the spherical calottes, spherical bowls with Omphalos and retracted rims, and a rim fragment from grave 54(.4), not taken into account because of its fragmentary state. ${ }^{66}$

Altogether 17 graves contain pottery as grave goods (Fig. 34) but we can only investigate 10 pottery types which occur more than once in Szentlőrinc (Fig. 19).

TANkó 2005, 156, Figs 1, 2.

GÁti 2014, 121.

GÁTI 2014, 117, Fig 2.1,2,3.

GÁti 2014, 123.

DizDAR 2010, 200, Grave LT 43,7, 305, Pl. 1.

Dizdar 2010, 299, 303; GÁti 2014, 117.

Dizdar 2010, 300.

DizDAR 2010; DizDar 2015, 56.

See GÁti 2014, Pls 3-4, 6. 


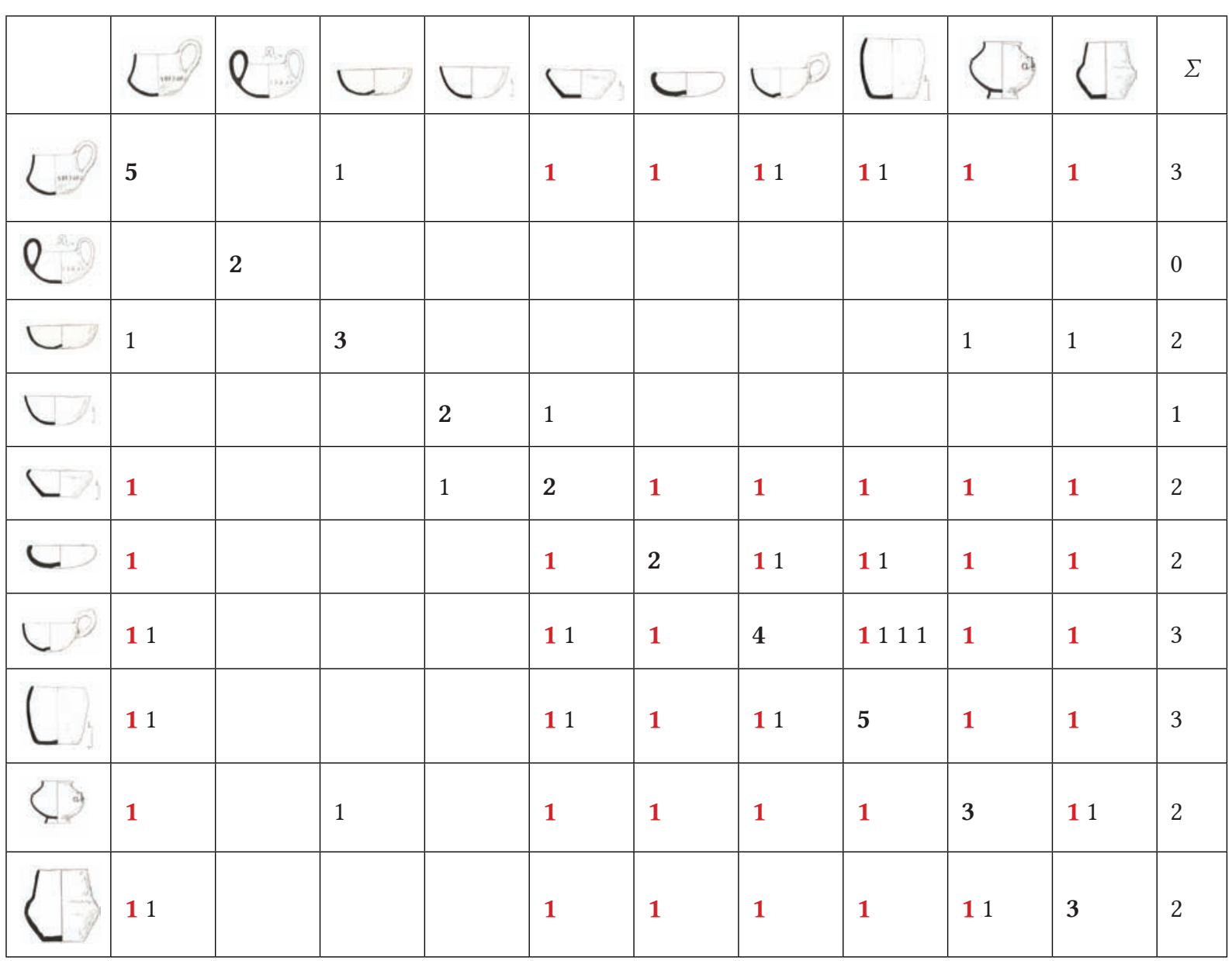

Fig. 19. The co-occurence of pottery types in Szentlörinc. The diagonal bold numbers depict the absolute occurrence of the pottery types in the cemetery. The number on the right shows how many times the pottery type occurs in association of other pottery types. The red numbers stand for the pottery present in grave 19.

The zoomorphic vessel and the one-handled mug have been left out, because they only occur once in the whole cemetery. Also graves which contain only one grave good have been left out, because they can not give any information of the association of pottery types. For grave 19 contains 7 out of the 10 pottery types, a Correspondence Analysis does not give us useful results (the red numbers in Fig. 19). A Seriation is more fruitful, but if we remove the graves with 1 refurbishment and grave 19 with almost all types of pottery, only 5 graves remain. Thus Correspondence Analysis, Seriation and Cluster Analysis done only with pottery types does not help us getting towards our answer. Associating gender with pottery (omitting the multiple graves and grave 19, but leaving graves with only one refurbishment) would give misleading results.

Thus a simple cross table has been chosen to highlight the result from Fig. 19. Considering only the graves with artifact types more than once present, we are only able to investigate 5 , respectively 6 graves with 9 of the 10 pottery types (present more than once in Szentlörinc) (Fig. 20).

It is apparent that we have to discuss grave 19 at this point, for several reasons. For one it seems to be an 'outlier' in the cemetery: situated in the North of the cemetery, among the graves of fibula group A while itself belonging to fibula group B (Figs. 33, 36). Also, the grave 
is defined as a cenotaph, with one Iron Certosa fibula, no human remains but 14 glass beads, 2 spindle whorls (from clay) and the highest number of pottery offerings in the whole cemetery, thus archaeologically considered as a female grave but with no traceable anthropolgical gender and has to be considered with caution in the statistical analysis ('Durchläufer' pottery types) - so it is used as a control grave, showing that the 7 pottery types it contains are mainly contemporaneous or rather persistent, thus the pottery in association with other artifacts in Szentlörinc cannot give any chronological indications, apart from certain specific forms, which on the other hand may have a longer time of circulation.

\begin{tabular}{|c|c|c|c|c|c|c|c|c|c|}
\hline & A11 & A31 & A4 & A5 & A32 & A13 & A2 & A21 & A22 \\
\hline Grave 9 & 1 & 1 & & & & & & & \\
\hline Grave 26 & & & 1 & 1 & & & & & \\
\hline Grave 20 & & & & & & 1 & 1 & & \\
\hline Grave 53 & & & & & & & & 1 & 1 \\
\hline Grave 54 & & & & & 1 & 1 & 1 & & \\
\hline Grave 19 & 1 & & & 1 & 1 & 1 & 1 & 1 & 1 \\
\hline
\end{tabular}

Fig. 20. Cross-table of the pottery types in Szentlörinc which appear more than once in the graves. The color red marks the female graves, blue color the male graves and black color the graves without known gender. Grave 19 is marked grey in its control function. For the coding of the pottery see the Appendix.

Taking the distribution of the pottery and the fibulae in Szentlörinc in account (Fig. 33), we can see, that from the 28 graves only in 6 (namely $9,19,35-36,38,44,63$ ) is pottery and fibulae associated, and this rare association is rather unlucky to get a meaningful (chronological) statement concerning the whole cemetery.

\section{Assessing Szentlőrinc}

Inspecting all graves and artifact types (including gender, grave orientation and burial custom) we can calculate their absolute co-occurrence.

A clustered Correlation plot based on the Chi-squared distance makes it very accessible, which artifact types occur together with which gender, burial custom and orientation. The highest Chi-squared limit $(\mathrm{X} 2=1)$ has been found to depict the absolute co-occurrences of artifacts and above mentioned variables in the cemetery. Negative correlations have been removed to give a better 'view' on the facts.

For a clear understanding of the co-occurence of all artifacts, a data set without multiple graves has been used for the Correlation plot (Fig. 19). Using a data set with multiple mixed gendered graves would have been misleading in the understanding of the male and female grave goods in Szentlőrinc ${ }^{67}$ The top left corner displays the female grave goods (F), which

67 The refurbishments of the multiple graves haven't been separated to the specific genders, because as further on it is made clear, certain artifacts cannot be not gender-assigned or better said are "genderless" (see the case of the knives) and a manual assignment of artifacts would have been too subjective. 
occur together most often. The center area shows the same for the male grave goods $(M)$ and near to the bottom we can see the grave goods from graves without known gender (U). We have to stress that in the Correlation plot those artifacts occur near to each other which have occurred together in one grave or have occurred together multiple times. Thus the Correlation plot does not depict a relative chronological sequence of the artifacts.

If we want to tackle the question of gender-specific refurbishments more thoroughly, we can understand it in the easiest way by sketching their network on the basis of the data used for Fig. $21 .^{68}$ We can clearly see, which artifact types occur together, and which orientation and burial custom is associated with which artifact, gender or graves without gender (Fig. 22).

This is a simple way to carve out female- and male- specific refurbishments and also of those in graves without known gender. The network shows only the most significant associations ${ }^{69}$, that is if we want to know more about the male or female refurbishments de facto, we must investigate them explicitly.

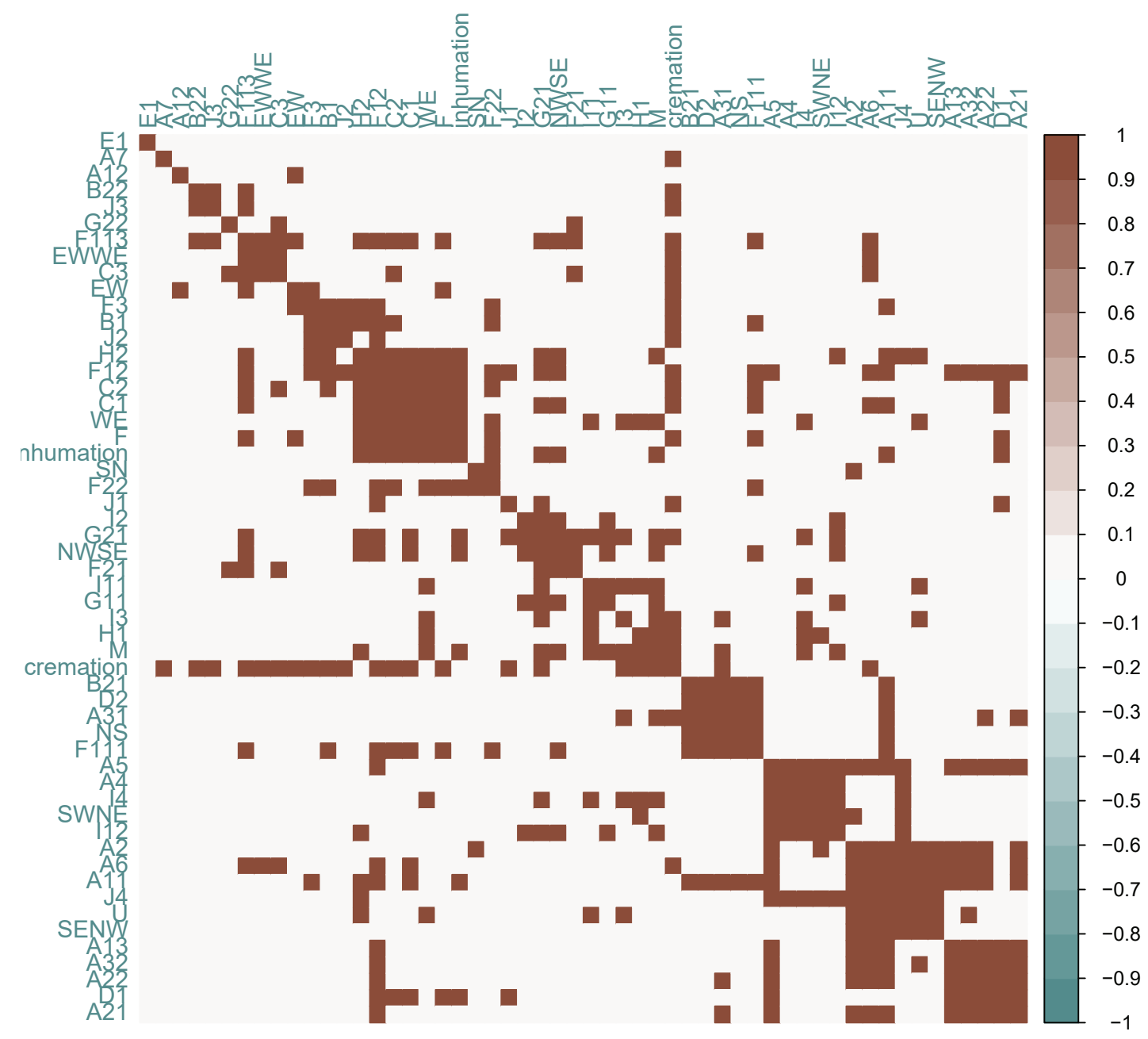

Fig. 21. A Correlation plot of the co-appearance of all artifact types in Szentlőrinc. The negative values are not represented. Encoding: F: female; M: male; U: unknown sex; for the coding of the artifacts see the Appendix.

68 Certainly the network of all artifacts can be sketched, but that would go too far in our case.

69 The network was created from the same distance-matrix, on which the correlation-plot in Fig. 19 is based on. 


\section{Inspecting the male graves}

Taking into consideration the graves which have been identified as male in the original publication, ${ }^{70}$ we can see that apart from one (grave 10), all are inhumations. Thus the variables concerning the burial custom is left out, to avoid disruption in the association.

Like in the case of the fibulae, we can see on the left of the Cluster Dendrogram the subgroups of the artifacts and on the top the groupings of the graves, which is what is in our focus (Fig. 23).

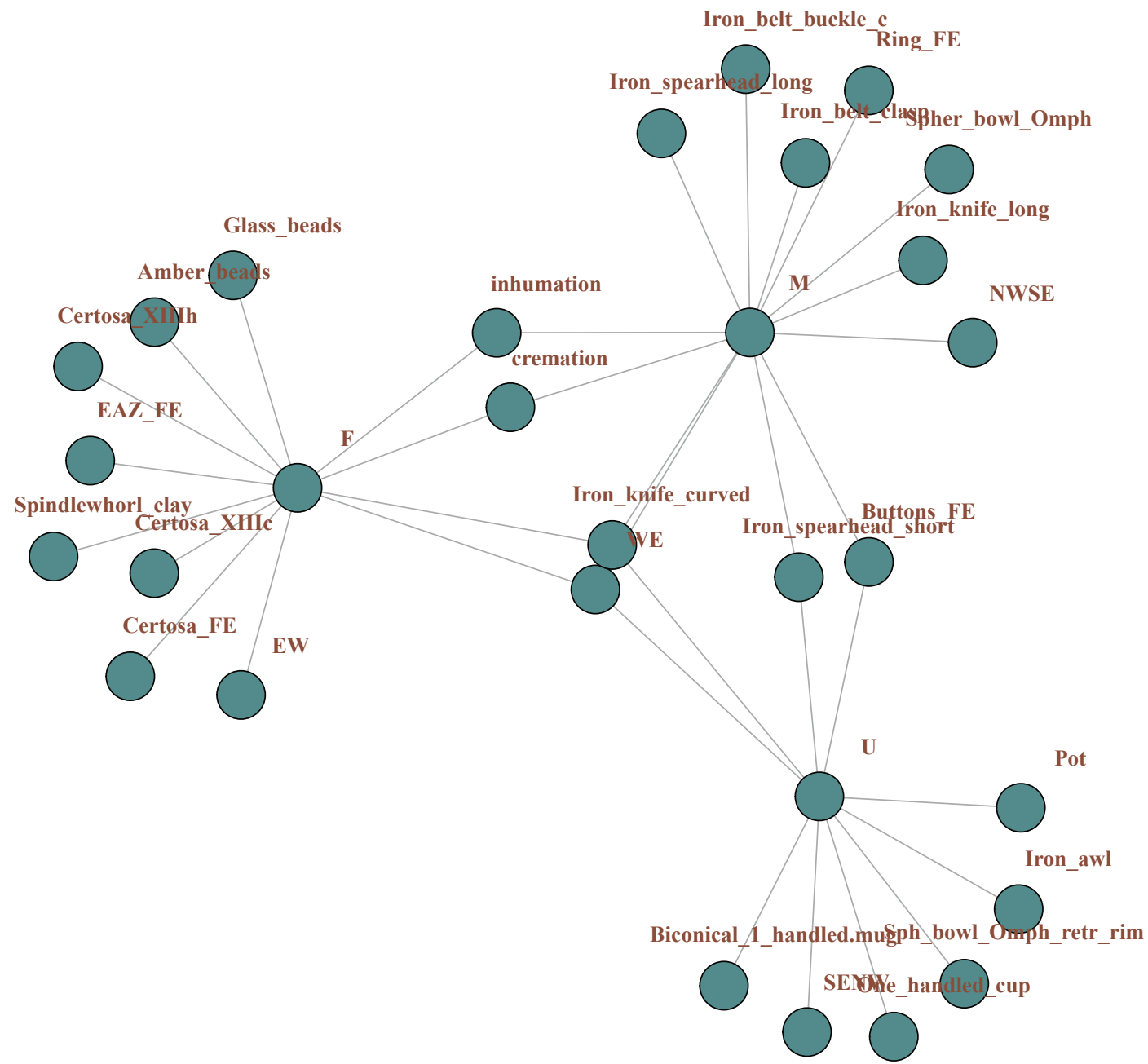

Fig. 22. A Network-analytical view of the most common gendered grave refurbishments in Szentlőrinc.

After eliminating all variables which could make the outline of the male-specific refurbishment unclear we are left with the male core grave goods (Fig. 35), that is: iron spears, iron belt clasps, iron belt buckles, iron rings and iron buttons. If we take the two different types of iron spears into account (one with the same length for the shaft and leaf and one with shorter leaf than shaft) and the two kinds of belt closure (belt clasp and buckle) and their association, we can outline in the male graves 3 groups (I, II and III) made clear by the Seriation combined with a Cluster Dendrogram. Grave 6 and 31 form a bridge between two weapon-customs: 
grave 31 contains a belt clasp and a belt buckle with the spear of group II. Group I does not contain any weapons, only iron buttons. Interpreting the Cluster Dendrogram chronologically is very tempting but we have to raise the question if we are dealing with a chronological or sociological factor.

\section{Inspecting the female graves}

In the case of the female graves the amber and glass beads are so-called 'Durchläufer' (a grave good being contained by almost all or most of the graves) and from another point of view also grave 19 (because it has almost exclusively pottery as refurbishment, apart from one iron Certosa fibula), and thus were taken out from the data used for the analysis. Artifacts with a single appearance have been left in the data (not being so numerous), not to arrive at the fibulae, by stripping the data too much (Fig. 24).

The order of the clusters of the artifacts (on the left axis of Fig. 24) does not reflect the sequence of the fibula types: the Certosa Type XIIIc and the Early La Tène-Scheme Fibulae changed places. This comes at the expense of not having very much grave goods per grave, but it also means that this combined analysis points to the fact that the time-span reflected in Szentlőrinc is relatively short.

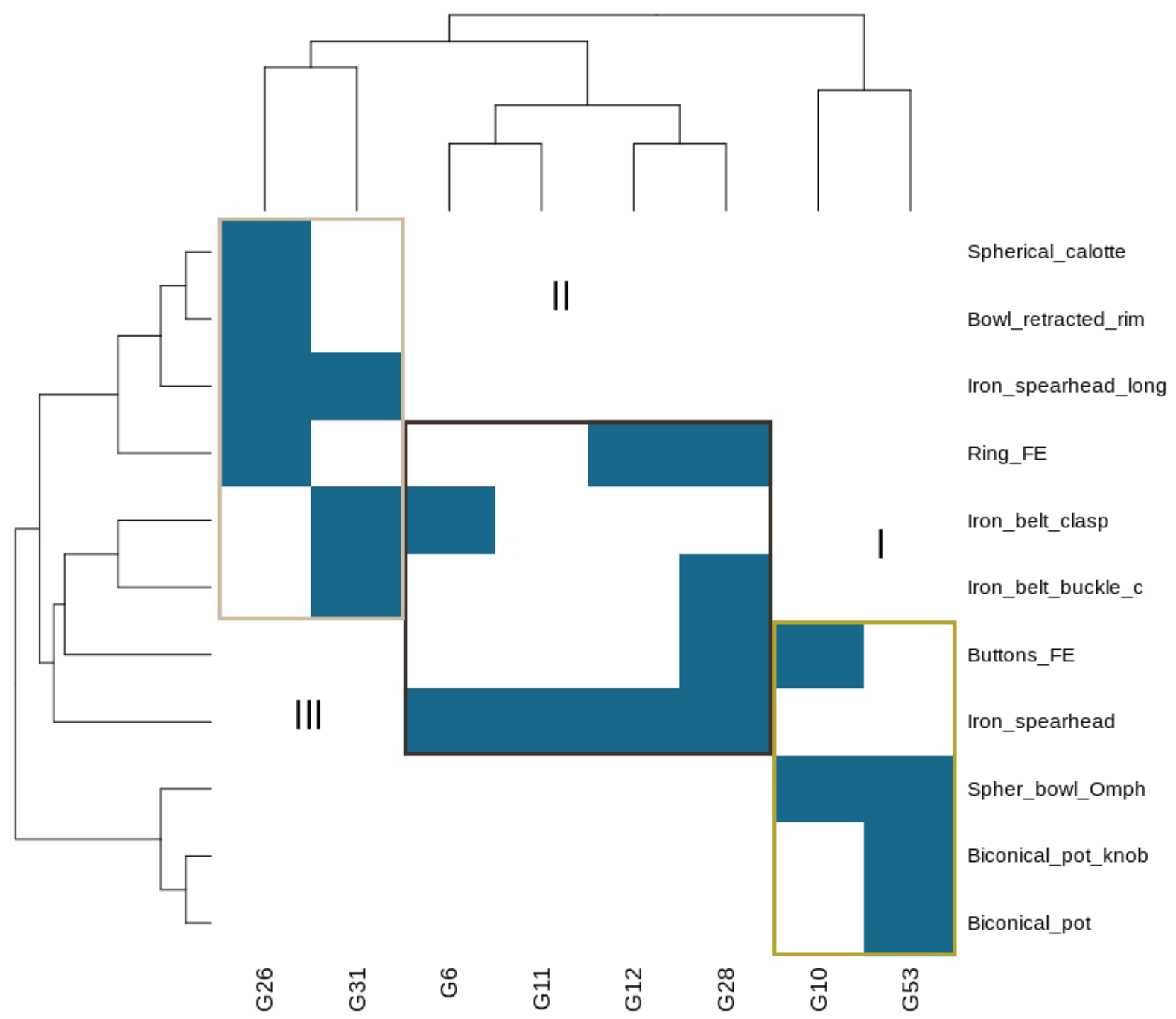

Fig. 23. Seriation combined with a Cluster Dendrogram of the male grave goods in Szentlörinc. 


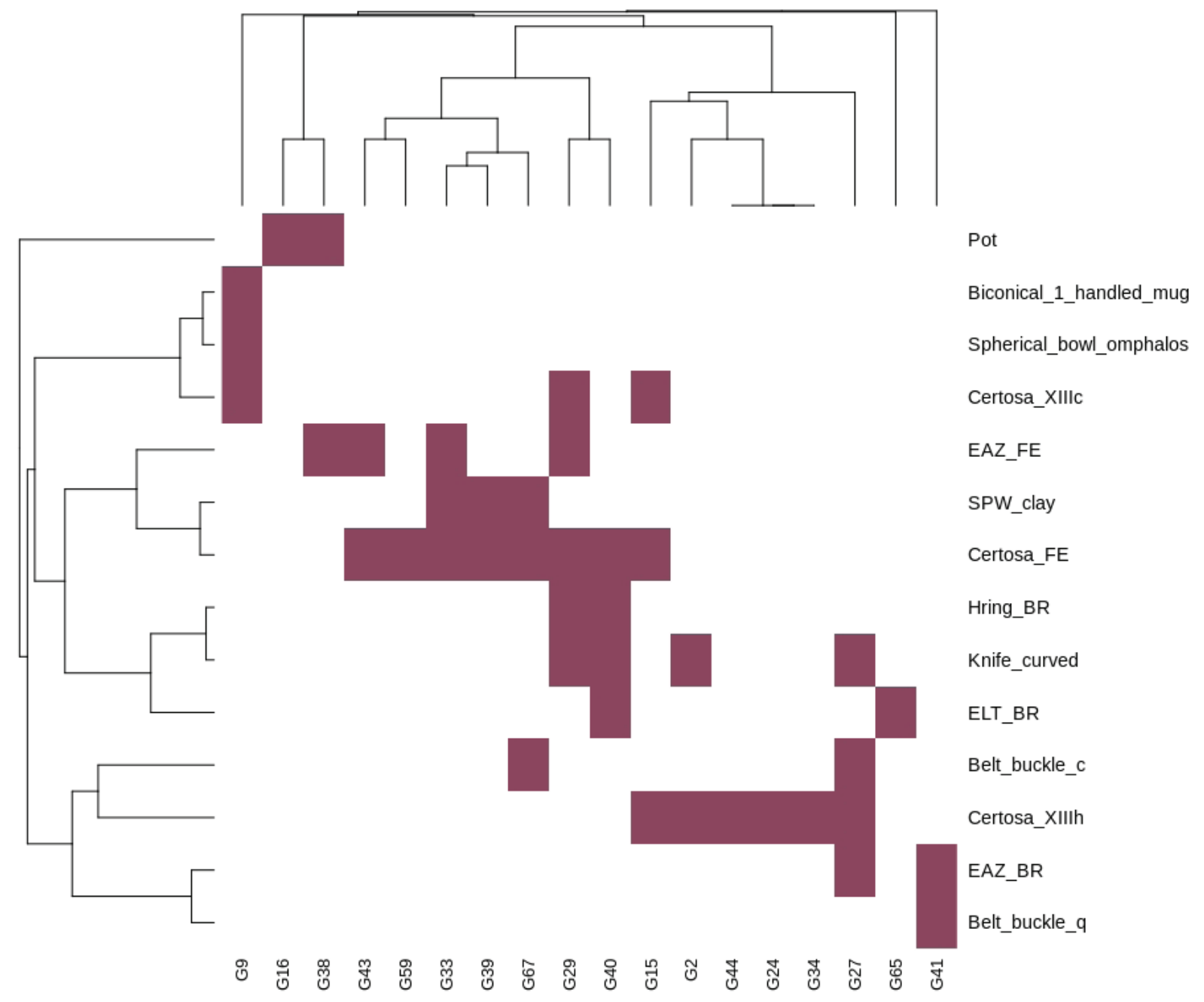

Fig. 24. Seriation combined with a Cluster Dendrogram of the female grave goods in Szentlörinc.

\section{Second side note: on knives in Szentlörinc}

Iron knives and curved iron knives as well as awls have not been taken into account yet, because they appear in both male and female graves (Fig. 35).

Two types of iron knives can be found in Szentlörinc. One type is comprised of long iron knives and the other of curved iron knives. Long Iron knives can be up to 3 times the length of the curved knives.

Knives appear in altogether 19 graves (Fig. 25). Long iron knives appear 6 and curved iron knives 15 times. These two knife-types appear two times together: once in a double burial (grave 3) and once as sole grave good in a male grave (grave 7). The question which arises is: do the two types of knives correlate with gender or chronological sequence or do these two knife-types not depend on any of these factors? Looking at a simple cross table (Fig. 26) we can see that two graves ( 3 and 7) contain both knife types and grave 3 and 35-36 are graves with multiple genders, which makes it difficult to assess if the knife belonged to one or the other gender. Three groups can be discerned: group a with long iron knives and multiple graves with 50-50\% dispersal of the gender (roughly estimated). The second group b, contains graves with both knife types (graves 3 and 7, forming a kind of a link between the two groups) and a third 
group (c) consists of the curved iron knives, distributed 50-50\% between genders. If we look at their distribution in the cemetery (Fig. 36), we can see, that group a is mainly dispersed in the $\mathrm{N}$ and SE of the cemetery (except of grave 55), group b in the $\mathrm{N}$ and group c shows a concentrations around the youngest graves in the SE, and also in the center of the cemetery.

\begin{tabular}{|c|c|c|c|c|}
\hline & $q$ & $0^{7}$ & Long Iron knife & Curved Iron knife \\
\hline G2 & 1 & 0 & 0 & 1 \\
\hline G3 & 1 & 1 & 1 & 1 \\
\hline G7 & 0 & 1 & 1 & 1 \\
\hline G11 & 0 & 0 & 0 & 1 \\
\hline G12 & 0 & 1 & 1 & 0 \\
\hline G16 & 1 & $\mathbf{0}$ & 1 & $\mathbf{0}$ \\
\hline G18 & 0 & 1 & 0 & 1 \\
\hline G20 & 0 & 0 & 0 & 1 \\
\hline G26 & 0 & 1 & 0 & 1 \\
\hline G27 & 1 & 0 & 0 & 1 \\
\hline G29 & 1 & 0 & 0 & 1 \\
\hline G31 & 0 & 1 & 0 & 1 \\
\hline G32 & 0 & 1 & 0 & 1 \\
\hline G35_36 & 1 & 1 & 1 & $\mathbf{0}$ \\
\hline G40 & 1 & 0 & 0 & 1 \\
\hline G55 & 0 & 1 & 1 & 0 \\
\hline G56 & 0 & 1 & 0 & 1 \\
\hline G62 & 0 & 1 & 0 & 1 \\
\hline G63 & 0 & 1 & 0 & 1 \\
\hline
\end{tabular}

Fig. 25. The co-occurence of knife types in Szentlörinc. Red connotes female graves, blue male graves and Bold on the other hand multiple graves and Italic graves without known gender.

\section{Towards a relative horizontal chronology}

Combining the analyses results of the fibulae, the male grave goods and the knives, we can say the following (Fig. 36).

The northern area of the cemetery is characterized by fibulae of group A (bronze Certosa Types XIIIh, XIIIc and bronze Eastern Alpine Zoomorphic fibulae), the southern/center area by fibulae of group B (iron Certosa and iron Eastern Alpine Zoomorphic fibulae) and the eastern area by group C (iron Eastern Alpine Zoomorphic fibulae and bronze Early La TèneScheme fibulae; compare Figs 33, 36).

We have to bear in mind that, on the basis of the statistical analyses conducted, bronze Eastern Alpine Zoomorphic fibulae seem to be contemporaneous with bronze Certosa (Types XIIIh and XIIIc and also XIIIf) fibulae (Fig. 18). Bronze Eastern Alpine Zoomorphic fibulae and the bronze Certosa fibulae appear to be dispersed diagonally through the cemetery (belonging to fibula group A) and seem to be substituted by their iron counterparts in group B. Further, we have seen that iron Eastern Alpine Zoomorphic fibulae appear either with Iron Certosa 
or bronze Early La Tène-Scheme fibulae (only once with a bronze Certosa XIIIc). This gives strong indications for the relative-chronological structure of the cemetery.

The Seriation of the male-specific refurbishments showed that two weapon-bearing groups are discernible: namely group II and III, with graves 6 and 31 as a bridge between the two groups (Fig. 36). Group III (graves 26 and 31 displaying spears with shorter leafs than shafts) is dispersed diagonally, NW to NE in the cemetery. Group II (graves 6, 11, 12 and 28, displaying spears with the same shaft and leaf length) can be located in the NE region of the cemetery.

\begin{tabular}{|l|c|c|}
\hline & Long Iron knife & Curved Iron knife \\
\hline Grave 12 & 1 & \\
\hline Grave 55 & 1 & \\
\hline Grave 35-36 & 1 & \\
\hline Grave 16 & 1 & \\
\hline Grave 3 & 1 & 1 \\
\hline Grave 7 & 1 & 1 \\
\hline Grave 2 & & 1 \\
\hline Grave 11 & & 1 \\
\hline Grave 18 & & 1 \\
\hline Grave 20 & & 1 \\
\hline Grave 26 & & 1 \\
\hline Grave 27 & & 1 \\
\hline Grave 29 & & 1 \\
\hline Grave 31 & & 1 \\
\hline Grave 32 & & \\
\hline Grave 40 & & \\
\hline Grave 56 & & \\
\hline Grave 62 & & \\
\hline Grave 63 & & \\
\hline
\end{tabular}

Fig. 26. Cross-table of the knife types in Szentlörinc. Red connotes female graves and blue the male graves. Bold connotes the multiple and Italic the graves without known gender.

If we include the multiple graves into the analysis, that is grave 3, a double grave (of female and male gender) belonging to group II with two fibulae types (Certosa Types XIIIc and XIIIh) belonging to the fibula group A and grave 35-36, another a double grave (of female and male gender) belonging to the group III and to the fibula group B, we can see, that these two graves give important clues to the structure of the cemetery, connecting the results of two statistical analysis.

At this point of the investigation it looks like that the group II male graves can be brought together with fibula group A (on the basis of grave 3) and group III can brought together with fibula group B (on the basis of grave 35-36).

When taking also the distribution of the iron knives in consideration, we can see in Fig. 36, that the two knife types (long iron knives (group a) and curved iron knives (group c)) occur 
with both male groups with weapons and all fibula groups (formulated in code in Fig. 36: BIIIa (grave 35-36, with a fibula from group B), IIIc (graves 26 and 31); IIc (grave 11), IIa (grave 12). The fibula group $C$ is prevalently present with the iron knife group 3 , that is the curved iron knives (formulated in code: $\mathrm{Cc}$ ) in the latest phase of Szentlörinc, but also with fibulae of group A (in code: Ac, graves 2 and 27). The double graves 3 and 35-36 are the only graves, where fibulae, male grave goods and knives are present together (formulated in code: AIIb; BIIa, red arrows in Fig. 27).

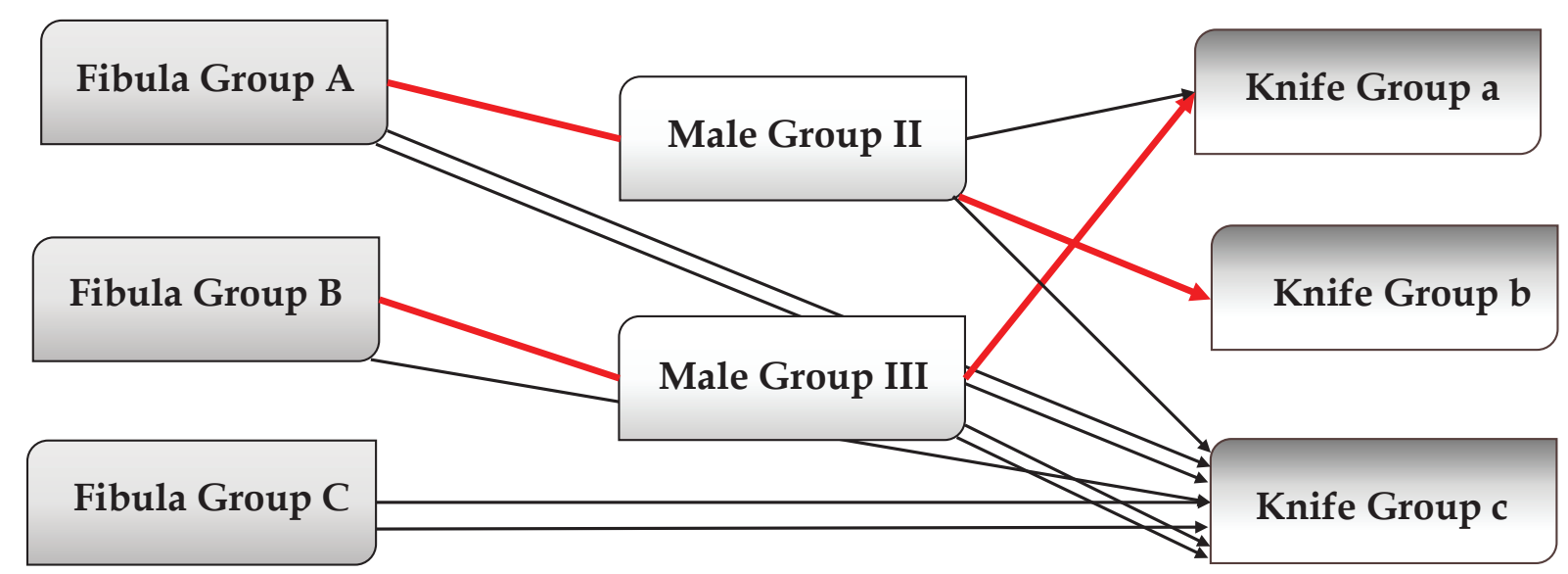

Fig. 27. Scheme of the quantitative relations between the fibula (A, B, C), the male (II, III) and the knife (a, b, c) groups. In red: the artifact combinations of graves 3 (AIIb) and 35-36 (BIIIa).

On the basis of the flowchart of the relation between fibulae, male grave groups and knife types we can say, that curved iron knives (group c) are present with all fibula groups and long iron knives are also present with fibula group B, thus we can express, that the distribution of the two knife types in the cemetery is neither gender related nor chronologically induced.

The dispersion of the grave goods discussed so far suggests, that there is a connection between fibula group A and the horse burials with bridles of Type Teleaga 2 (graves 52, 58 and 60: which are situated south to the graves with fibulae of group A) and that fibula group B padded the space between the graves in the cemetery (especially striking is the position of grave 19), including the horse burial with the bridle Teleaga Type 3 (grave 61). Subsequently the graves with fibula group $\mathrm{C}$ followed.

What do the other artifacts in Szentlörinc tell us? Reflecting the fact, that grave 32 contains a double-headed bronze needle, we can place the grave at the beginning of occupation of the cemetery, based on the fact, that double-headed bronze needle are characteristic in the earlier horizon of Sanski Most, which precedes Szentlonrinc. ${ }^{71}$ On the other hand, it also could be 'keimelia', passed on to later generations. Before recollecting the facts known about the relative sequence of certain graves on the basis of the conducted analyses, we also have to take into account the graves lacking grave goods (marked grey in Fig. 36). After this recollection only a small number of the graves are still to be discussed.

Graves 13 and 21-22 contain kantharoi and Certosa Type XIIIf bronze fibulae, which places grave 21-22 in the fibula group A. Grave 20 harbors a biconical one-handled mug with a rela- 
tively similar profile to that of grave 9, although displaying different grave orientations. Grave 30 can be brought into relation with graves 26 and 20, on the basis of the contained iron awl, which (including grave 32) might at least coincide with the earliest horizon of the cemetery.

Grave 54 can be linked to grave 44 on the basis of the one-handled cup (and also being in the proximity), which on the other hand connects to grave 20. At this point we have to mention the zoomorph fragment from grave 46, being in the vicinity of graves 44 and 54 and which including the one handled cup with Omphalos reflect scythian influence, such as grave 34, containing a bronze Sceptrum and Certosa Type XIIIh fibula (probably taking place parallel with fibula group A). Moreover, the horse burials are near to graves 44, 46 and 54 (Fig. 36).

Graves 1, 6, 7, 16, 18, 28 and 62 do not contain artifacts (or a group of artifacts) which could be brought into relation with other artifacts in the cemetery, so it is hard to fit them into the relative chronology of the cemetery.

At this point it can be enunciated on the basis of the multivariate statistical analyses and the indirect conclusions, that three phases can be discerned in Szentlörinc, mainly supported by the fibulae occurring throughout the cemetery (Figs 33, 36). The other artifacts alone are not significant enough, only in relation to each other.

The older phase is represented by the bronze Certosa fibulae of Type XIII c, $\mathrm{f}$ and $\mathrm{h}$, bronze bronze Eastern Alpine Zoomorphic fibulae (fibula group A) and iron spears with short leafs and short shafts, kantharoi, iron awls and one-handled cups. This can be consolidated with the first phase of Jerem 1968. On the basis of the co-occurence of Certosa fibulae Type XIII $\mathrm{c}$ and $\mathrm{h}$ and spears of the second male group, in grave 3, the fibula group A can be brought together with the male group 2 (see also Fig. 27). The graves are distributed in the northern part of the cemetery, with graves 41 and 44 arriving until the line of the horse graves, which points to the supposition that horse graves 52, 58 and 60 probably belonged to the first phase (we cannot say anything about horse graves 48 and 51, containing only bones) and later on got incorporated into the cemetery when the second phase was established.

The next phase is introduced by the appearance of iron fibulae, namely iron Certosa and iron Eastern Alpine Zoomorphic fibulae, still occurring together with bronze Certosa Type XIII c in grave 29, which shows shift from bronze to iron material (fibula group B).

The last, third phase (fibula group C) is dominated by Early La Tène-Scheme fibulae in the southeastern corner of the cemetery.

This already points to the main problem or characteristic which we encounter in Szentlörinc: it is difficult to draw clear lines between the different horizons or groups, because the cemetery was used complementary, which also points to the fact that the duration of the use of the cemetery was rather short. ${ }^{72}$ Also it has to be stressed, that there are graves containing no grave goods which also makes the assessment of Szentlörinc difficult.

This relative horizontal chronology was mainly based on the fibulae in Szentlörinc and is only an indication - the problems concerning the multivariate statistical analysis of other types of artifacts has already been discussed. 


\section{Discussion}

The review of certain artifact types from Szentlörinc has shown, that on the basis of the relatively few artifact types, the low number of artifacts in the graves and their sparse co-occurrence, it is not easy to tackle fine-chronological results from Szentlörinc. Still, as shown in the sections III and IV multivariate statistics can give us answers. The most precise relative chronological reference for the utilization of the cemetery are the fibulae types and their period of circulation, even though they do not represent the whole cemetery, because almost half of the graves are missing any grave goods. The other artifact types in the cemetery could be fitted loosely in this typo-chronological grid.

To contextualize Szentlőrinc in a micro- and macro-regional relation in the Southwest-Pannonian - Northwest-Balkan region, we not only have to examine the chronological categorisation of the most prominent fibulae types of the cemetery, but also call on the site of Sanski Most, which is often brought into relation with Szentlörinc. ${ }^{73}$

The early phase of Sanski Most is displaying diverse earlier Certosa Types (III, V, VII, XIIIa, XIIIc), and can be put in context with Beremend ${ }^{74}$ on the basis of Certosa Types III, V and VII, Violin fibulae and Astragalus-belts, which constitute an earlier phase than Szentlörinc ${ }^{75}$ and represent the so-called Pre-Negova (older Certosa) Horizon, to which the earlier Certosa XIII forms belong. ${ }^{76}$ The later phase of Sanski Most on the other hand can be brought in relation with a significant part of the fibula spectrum of Szentlorinc, both representing the costume traditions of the older Negova Horizon through the Certosa Types XIII c, f and h fibulae, Eastern Alpine Zoomorphic fibulae and Early La Tène-Scheme fibulae. ${ }^{77}$ The only difference is, that in Szentlőrinc the Certosa Type XIIIh does not appear together with Early La TèneScheme fibulae, only with Iron Certosa fibulae and Iron Eastern Alpine Zoomorphic fibulae. Thus the Type XIIIh fibulae in Sanski Most are supposedly later, than in Szentlörinc. ${ }^{78}$ Certosa Type XIIIc fibulae usually appear together with earlier Certosa types, such as in the early phase of Sanski Most and their appearance together with Eastern Alpine Zoomorphic Fibulae, Certosa XIIIh and Iron Certosa fibulae in Szentlörinc shows probably the last phase of their circulation time, similarly to the Certosa Type XIIIf. ${ }^{79}$

If we take the distribution of the Certosa fibula Type XIIIh into account as outlined in DizDAR 2015 (Fig. 37), we have to support his conclusion,,$^{80}$ that this specific type of Certosa fibula was a local (South-)Pannonian product. Only a few specimens have been found north of Lake Balaton. The Type XIIIh fibulae can be dated to the last third of the $5^{\text {th }}$ century and the first quarter of the $4^{\text {th }}$ century BC. ${ }^{81}$

Eastern Alpine Zoomorphic fibulae are seen as an indicator of the early LT A period but have clear roots in the HaD3 period, as Th. Stöllner could show in his seriation of the Inn-Salzach region in Austria. ${ }^{82}$ They can be located in his phase IV (early LTA) - IV/V, that is the devel-

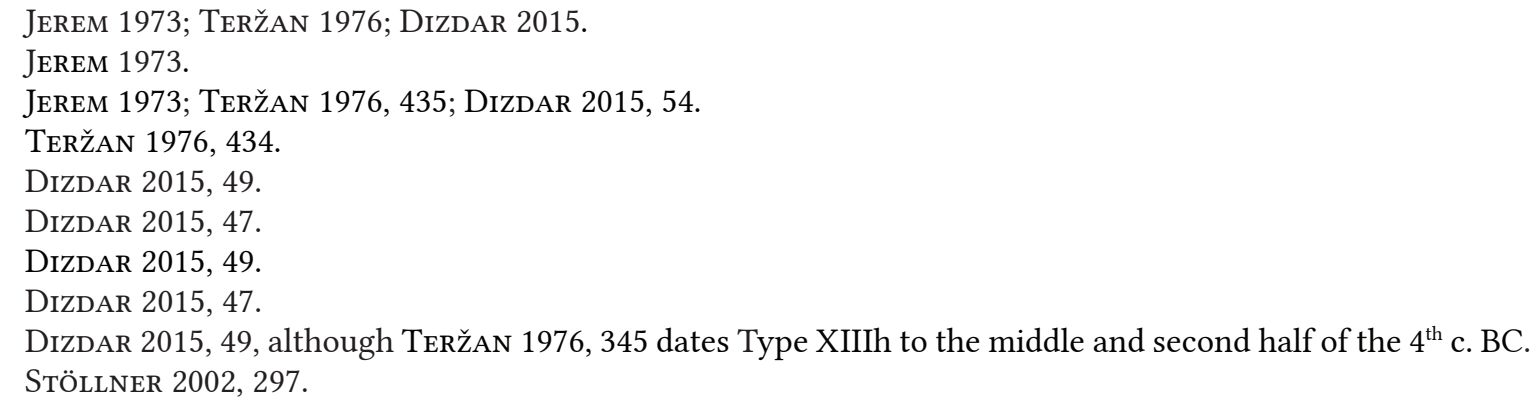


oped LTA ${ }^{83}$ and absolute chronologically speaking in the $2^{\text {nd }}$ quarter of the 5 th $\mathrm{c}$. BC to the $3^{\text {rd }}$ quarter of the $5^{\text {th }} \mathrm{c}$. BC in the North-Western Eastern Celtic area. ${ }^{84}$

The Early La Tène-Scheme fibulae ${ }^{85}$ find their place successively in Stöllners' phase IV/V and $\mathrm{V}^{86}$ that is the late LTA, which is then again chronologically speaking from the $3^{\text {rd }}$ quarter of the $5^{\text {th }} \mathrm{c}$. BC to around the $1^{\text {st }}$ quarter of the $4^{\text {th }} \mathrm{c}$. BC. ${ }^{87}$ Božič places the Early La Tène-Scheme fibulae together with the Certosa Type XIIIh fibulae in his Čurug phase, ${ }^{88}$ which also fits together with the relative chronology of Szentlörinc, apart from the fact that Certosa Type XIIIh fibulae do not occur with Early La Tène Scheme fibulae, as elaborated above and this fact is clearly a peculiarity of Szentlörinc.

To round the chronological setting of Szentlörinc up, at this point we have to refer to a recent crucial and in-depth study about the Bronze and Iron Ages of Slovenia. ${ }^{89}$ This study delivers chronological fixpoints $\left({ }^{14} \mathrm{C}\right.$ dates) from different archaeological contexts from Slovenia, amongst which are sampled graves from the Certosa and the Negova Horizon.

Three dates are available for the Certosa horizon. The first date (KIA34808, Fig. 28, top left, Fig. 29) originates from grave 99, from tumulus 48 in Stična, which grave goods can be placed to the beginning of the Certosa horizon, containing a Szentes-Vekerzug bridle Type Teleaga $1^{90}$ and two Certosa Type V fibulae. The result is a radiocarbon age of $2466 \pm 27 \mathrm{BP}$ which translated into a modelled date in the second half of the 6th c. BC (GPP 555 \pm 39 , MM 528). ${ }^{91}$ The second and third samples (KIA37317, KIA37318, Fig. 28, top right and center, Fig. 29) come from grave 2 and grave 4 in Grofove nijve near Drnovo. While grave 2 contained one Certosa Type V fibula and two band bow fibulae, grave 4 contained three Certosa Type V fibulae. The radiocarbon age for grave 4 is $2477 \pm 27 \mathrm{BP}$ which translates to a modelled radiocarbon date of the second half of the $6^{\text {th }}$ century BC (MM 536) and for grave 2 is $2411 \pm 27 \mathrm{BP}$, which translates to a modelled radiocarbon data the beginning of the 5th century BC (MM 497). ${ }^{92}$

Two dates are available for the Negova horizon, both from Novo Mesto. The first sample is from grave 3, tumulus IV at Kandija (KIA45221, Fig. 28, bottom right, Fig. 29, already mentioned in connection with the bridles: see Figs 11, 12), containing fibulae of Certosa Type X and XI, two Eastern Alpine Zoomorphic fibulae and also a Szentes-Vekerzug bridle of Teleaga Type 3 . The radiocarbon age is $2238 \pm 55 \mathrm{BP}$, which translates to a modelled radiocarbon date of the first half of the $4^{\text {th }}$ century. ${ }^{93}$ The second sample is from grave 458 in Kapiteljska Njiva (KIA37269, Fig. 28, bottom left, Fig. 29), containing a Certosa Type X fibula, delivering a radiocarbon date of $2151 \pm 22 \mathrm{BP}$ and translating into a modelled radiocarbon date of the second half of the $4^{\text {th }}$ century BC (GPP $\left.325 \pm 27 \mathrm{cal} \mathrm{BC}\right){ }^{94}$

STÖLLNER 2002, Beilage 1.

STÖLLNER 2002, 311.

STÖLLNER 2002, 66.

STÖLlNER 2002, Beilage 1.

STÖLLNER 2002, 311. Although Th. Stöllners work regards a different region, still, the relative chronological indications and circumstances are similar.

Božıč 1981, 326.

TERŽAN - ČrešnAR 2014.

Teleaga 2017, 56.

TERŽAN - ČreŠNAR 2014, 457-459, 720.

TERŽAN - ČrešNAR 2014, 491-504, 720-721.

TERŽAN - ČrešNAR 2014, 486-490, 721; TELEAGA 2017, 57.

TERŽAN - ČrešNAR 2014, 483-484, 722. 

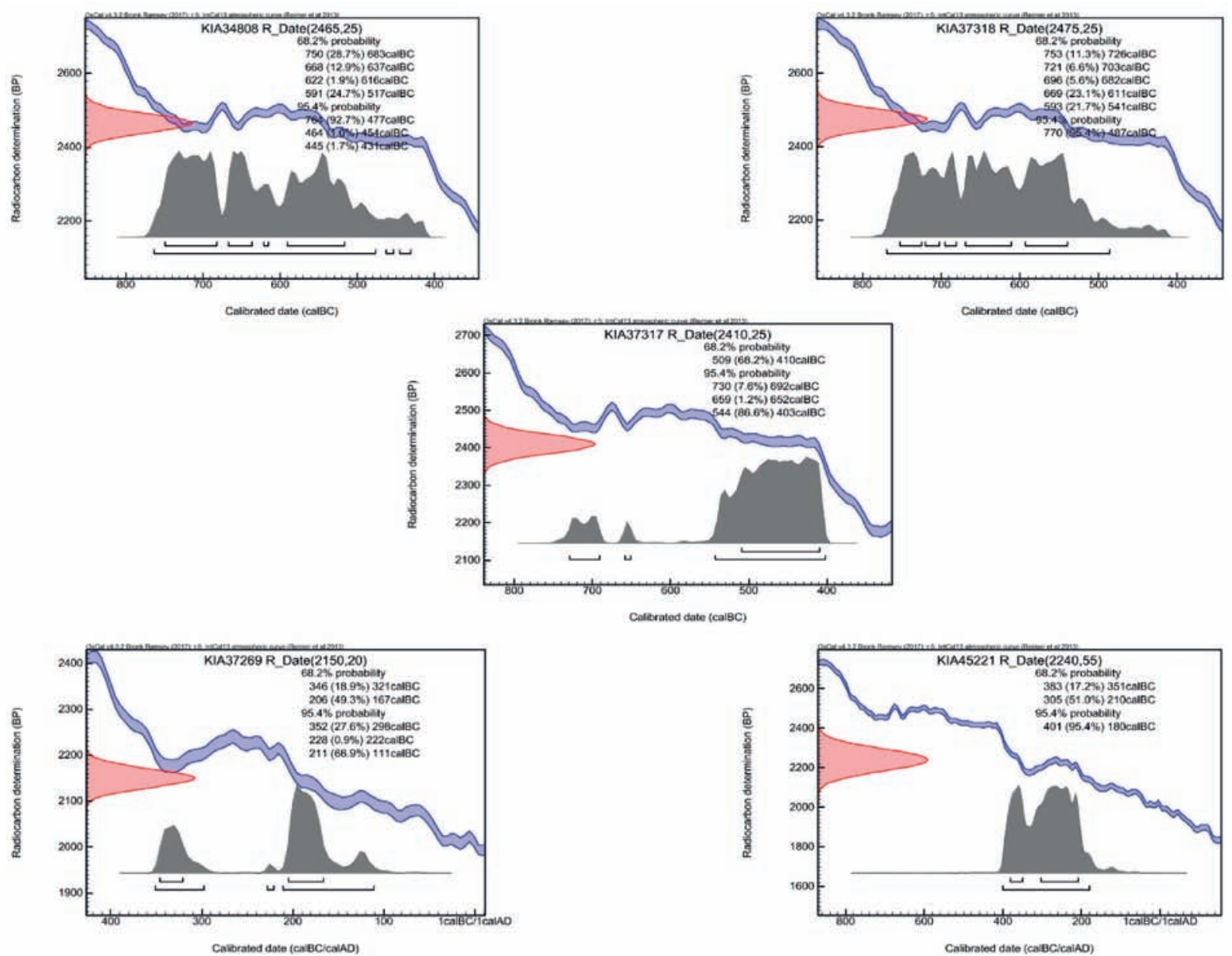

Fig. 28. The calibrated ${ }^{14} \mathrm{C}$ dates after TERŽAN - ČEŠNAR 2014.

To be able to place Szentlörinc chronologically in this sequence, we have to discuss the microand macro region of the cemetery more in depth. On the basis of the similar type spectrum of Szentlörinc to other sites in Southwest-Hungary and the North-West Balkan (stressed above) we can attribute the material from Szentlörinc (and Southwest Hungary) to the material culture of the Southeast Pannonian Late Hallstatt/Syrmian Group. ${ }^{95}$

The Srem group (Fig. 38) was first circumscribed by M. Garašanin in 1973, mainly on the basis of stray finds. ${ }^{96}$ Certain characteristic archaeological material could be attributed to the group, like Astragalus type belts, Certosa fibulae, knives with curved blades, long spearheads, glass bead necklaces, situlae, cowrie shells and kantharoi and in addition horse burials with harness, biritual burial customs, flat cemeteries and greek-italic imports. ${ }^{97}$ Since then the Srem Group was for a long time almost exclusively known from cemeteries - almost no settlements are known. A unique addition is the settlement of Szajk ${ }^{98}$ which has been excavated in the vicinity of Szentlörinc. Settlements of the Srem group are unprecedented from County Baranya in Southwest Hungary, which constitutes the northeastern limits of the Srem group. 
Ágnes ScHNEIDER

\begin{tabular}{|c|c|}
\hline KIA34808/1 & So Wood, alkali residue, $3.4 \mathrm{mg} \mathrm{C}$ \\
\hline Corrected pMC & $73.68 \pm 0.28$ \\
\hline$\delta^{13} \mathrm{C}\left(\%_{0}\right)$ & $-29.77 \pm 0.97$ \\
\hline Conventional age & $2455 \pm 30 \mathrm{BP}$ \\
\hline KIA34808/2 & So/So Wood, alkali residue, $3.7 \mathrm{mg} \mathrm{C}$ \\
\hline Corrected pMC & $73.56 \pm 0.25$ \\
\hline$\delta^{13} \mathrm{C}\left(\%_{0}\right)$ & $-26.53 \pm 0.32$ \\
\hline Conventional age & $2465 \pm 25 \mathrm{BP}$ \\
\hline Radiocarbon age & $2466 \pm 27 \mathrm{BP}$ \\
\hline KIA37317 & Bone, collagen, $3.8 \mathrm{mg} \mathrm{C}$ \\
\hline Corrected pMC & $74.07 \pm 0.25$ \\
\hline$\delta^{13} \mathrm{C}\left(\%_{0}\right)$ & $-16.45 \pm 0.16$ \\
\hline Conventional age & $2410 \pm 25 \mathrm{BP}$ \\
\hline Radiocarbon age & $2411 \pm 27 \mathrm{BP}$ \\
\hline KIA37318 & Bone, collagen, $3.8 \mathrm{mg} \mathrm{C}$ \\
\hline Corrected pMC & $73.46 \pm 0.24$ \\
\hline$\delta^{13} \mathrm{C}\left(\%_{0}\right)$ & $-13.05 \pm 0.38$ \\
\hline Conventional age & $2475 \pm 25 \mathrm{BP}$ \\
\hline Radiocarbon age & $2477 \pm 27 \mathrm{BP}$ \\
\hline KIA45221 & Horse tooth, apatite, $0.6 \mathrm{mg} \mathrm{C}$ \\
\hline Corrected pMC & $75.69 \pm 0.52$ \\
\hline$\delta^{13} \mathrm{C}\left(\%_{0}\right)$ & $-10.75 \pm 0.06$ \\
\hline Conventional age & $2240 \pm 55 \mathrm{BP}$ \\
\hline Radiocarbon age & $2238 \pm 55 \mathrm{BP}$ \\
\hline KIA37269 & Cremated bone, apatite, $4.0 \mathrm{mg} \mathrm{C}$ \\
\hline Corrected pMC & $76.50 \pm 0.20$ \\
\hline$\delta^{13} \mathrm{C}\left(\%_{0}\right)$ & $-22.70 \pm 0.18$ \\
\hline Conventional age & $2150 \pm 20 \mathrm{BP}$ \\
\hline Radiocarbon age & $2151 \pm 22 \mathrm{BP}$ \\
\hline
\end{tabular}

Fig. 29. The result of the radiocarbon analysis performed at the Leibniz Labor für Altersbestimmung und Isotopenforschung, Christian-Albrechts Universität Kiel. After TERŽAN - ČEŠNAR 2014, 459-504.

The probability span of the radiocarbon dates for the Early Iron Age is relatively broad and so less precise (the so-called 'Hallstatt plateau'). Therefore specific archaeological contexts (characteristic types of material culture) have been sampled in the study conducted by B. Teržan, M. Črešnar and colleagues ${ }^{99}$ and the archaeological and the radiocarbon date has been compared and because of the long probability spans with peaks of lower or greater probability, 
peaks have been chosen which corresponded best with the archaeological data (independently from the probability percentage). Thus 'GPP' stands for greatest probability peak and 'MM' for modelled median. ${ }^{100}$

The Srem group initiates with a formative phase, which is only represented by sparse finds, e.g. from Banoštor and can be dated around mid $6^{\text {th }} \mathrm{c} . \mathrm{BC} \cdot{ }^{101}$ To the subsequent early phase belongs amongst others Beremend and the early phase of Sanksi Most, characterized by Certosa type V fibulae (the later Certosa horizon) and chronologically it can be put between the $6^{\text {th }}$ and during the first half of the $5^{\text {th }} \mathrm{c} . \mathrm{BC} .{ }^{102}$ The later phase is characterized by Eastern Alpine Zoomorphic fibulae and Certosa Type XIII fibulae and can be identified in Szentlörinc and as the later phase in Sanski Most (the Negova horizon) and can be put between the second half of the $5^{\text {th }}$ and the beginning of the $4^{\text {th }} \mathrm{c}$. BC. ${ }^{103}$ The youngest phase which corresponds to the Čurug phase of Božič with the appearance of Early La Tène-Scheme fibulae can be dated to the second quarter of the $4^{\text {th }}$ c. BC. ${ }^{104} \mathrm{M}$. Dizdar suggested in 2015 a new name: the Osijek Group. ${ }^{105}$

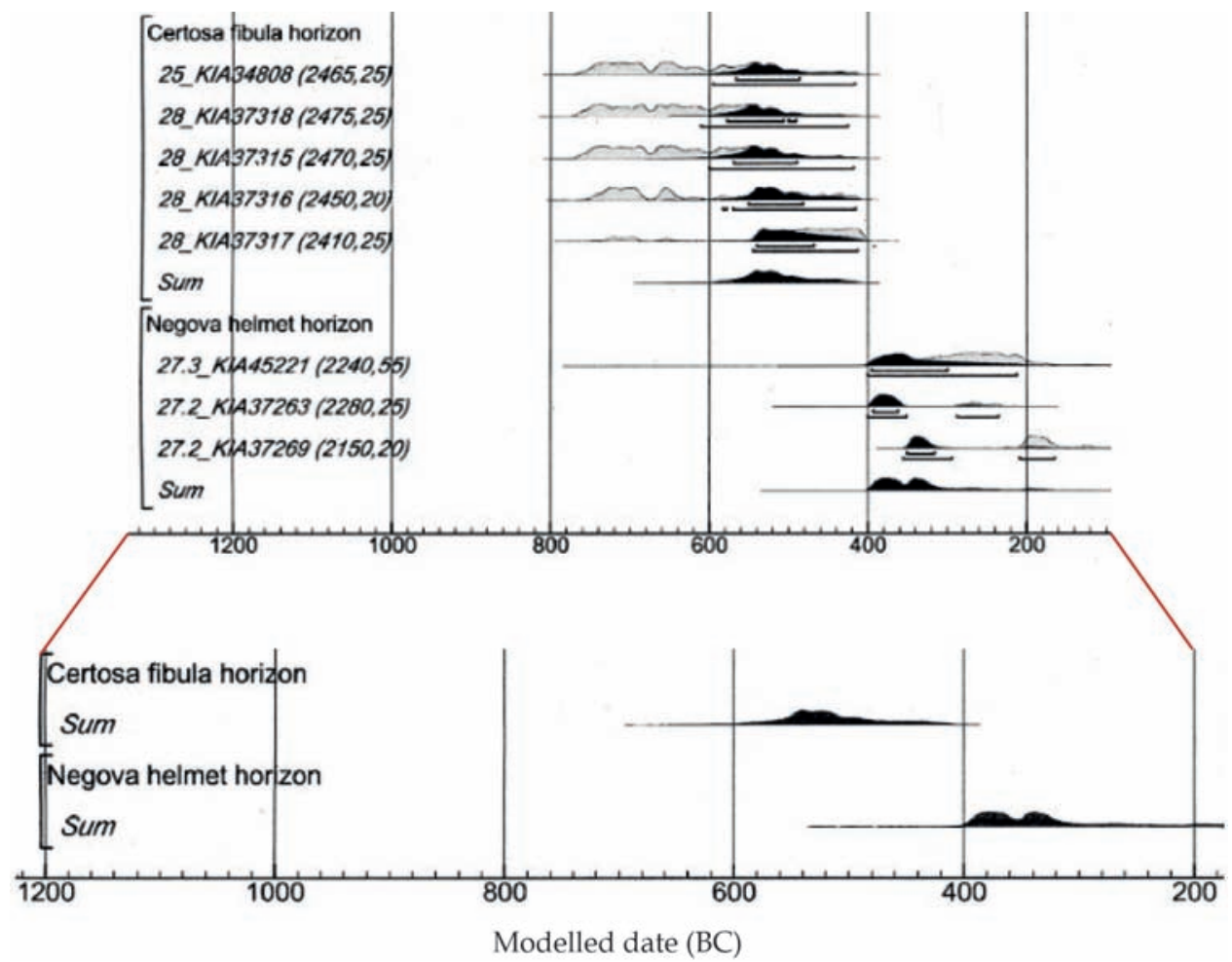

Fig. 30. The sequence of the calibrated ${ }^{14} \mathrm{C}$ dates for the Certosa and Negova horizons (after TERžAN ČEŠNAR 2014, 723, 725).

Referring to the five radiocarbon dates relevant for Szentlörinc, the Certosa and Negova horizons are delineating themselves very clearly based on TERŽAN - ČREŠNAR 2014 (Fig. 30). Also, it has to be pointed out, that the results for both horizons are not based on many samples and for our case three fixpoints are terminus ante quem and one is terminus post quem dates and

100 TERŽAN - ČREŠNAR 2014, 703-704

101 Dizdar 2015, 52; Dizdar 2019, 322.

102 DizDAR 2019, 323.

103 DiZDAR 2019, 323.

104 Medović 2002; Dizdar 2015, 51-57; Dizdar 2019, 323; Božıč 1981, 326, 330.

105 DizDAR 2015, 51. 
only one ${ }^{14} \mathrm{C}$ date has actual relations to the artifacts in Szentlörinc which means, that these results can be used more likely as a strong chronological trend.

Nevertheless, we have to sum up what we know about our chronological fix-points (Fig. 31) and we also have to bear in mind that 2 bridle types (three specimen of Type Teleaga 2 and one specimen of Type Teleaga 3) are present in Szentlőrinc, each pinpointing a circulation time.

\begin{tabular}{|c|c|c|c|}
\hline Sample & Location & Relevant Artifacts & Modelled ${ }^{14} \mathrm{C}$ age \\
\hline \multicolumn{4}{|c|}{ Certosa Horizon } \\
\hline KIA34808 & grave 99 , tumulus 48 , Stična & $\begin{array}{l}\text { Szentes-Vekerzug Bridle Type } 1 \text {, } \\
2 \text { Certosa Type V fibulae }\end{array}$ & $\begin{array}{l}\text { GPP } 555 \pm 39 \text { cal BC, } \\
\text { MM } 528 \\
\text { 2nd half of } 6 \text { th c. BC }\end{array}$ \\
\hline KIA37318 & grave 4, Grofove nijve, Drnovo & 3 Certosa Type V fibulae & $\begin{array}{l}\text { MM 536, } \\
\text { 2nd half of the } 6 \text { th c. BC }\end{array}$ \\
\hline KIA37317 & grave 2, Grofove nijve, Drnovo & $\begin{array}{c}1 \text { Certosa Type V fibula, } 2 \text { band } \\
\text { bow fibulae }\end{array}$ & $\begin{array}{l}\text { MM497, } \\
\text { beginning of the } 5 \text { th c. BC }\end{array}$ \\
\hline \multicolumn{4}{|c|}{ Negova Horizon } \\
\hline KIA45221 & $\begin{array}{c}\text { grave 3, tumulus IV, Kandija, } \\
\text { Novo Mesto }\end{array}$ & $\begin{array}{c}1 \text { Certosa Type X fibula, } \\
1 \text { bronze Certosa Type XI, } \\
2 \text { bronze EAZ fibula } \\
\text { Szentes-Vekerzug Bridle Type } 3\end{array}$ & 1st half of the 4 th c. BC \\
\hline KIA37269 & $\begin{array}{c}\text { grave 458, Kapiteljska Njiva, } \\
\text { Novo Mesto }\end{array}$ & 1 bronze Certosa Type X fibula & $\begin{array}{c}\text { GPP } 325 \pm 27 \mathrm{cal} \mathrm{BC} \\
\text { 2nd half of the } 4 \text { th c. BC }\end{array}$ \\
\hline
\end{tabular}

Fig. 31. The modelled radiocarbon dates for Slovenian Iron Age graves after TERŽAN - ČEŠNAR 2014, with the relevant artifacts showing a connection to Szentlőrinc. The sample which has actual relations to the artifacts in Szentlörinc is displayed in bold.

Attempting to bring the relative chronology of the cemetery (based on the multivariate statistical analysis of the fibulae), the chronological footprint of certain artifacts in the cemetery and the known absolute chronological fix dates together, it can be said, that the cemetery of Szentlörinc might have been used for a longer period than supposed until now (Fig. 32). ${ }^{106}$

Szentlörinc fits well to the later and and youngest phase of the Srem group, but might have already started in the later Certosa Horizon - in other words: (HaD3)/LTA - LTB1, that is Horizons 9 and mainly 10 of PARzINGER $1988 .{ }^{107}$

The cemetery of Szentlörinc combines diverse influences from the Southeast Alpine region, the Northwest Balkans, Southwest Pannonia (the local element) and Vekerzug-type material (horse harnesses which are hard to incorporate into the material of the cemetery) and amalgamates them to a distinctive cultural context. Apart from the moderate number of artifacts this is also a reason why it is a challenge to analyze Szentlonrinc in its regional context.

106 The last third of the $5^{\text {th }}$ century to the first half of the $4^{\text {th }}$ century BC; JEREM 1968, 200; DizDAR 2015, 54; STÖLLNER 2002, 311.

107 PARZINGER 1988, 107, 125, 314. 


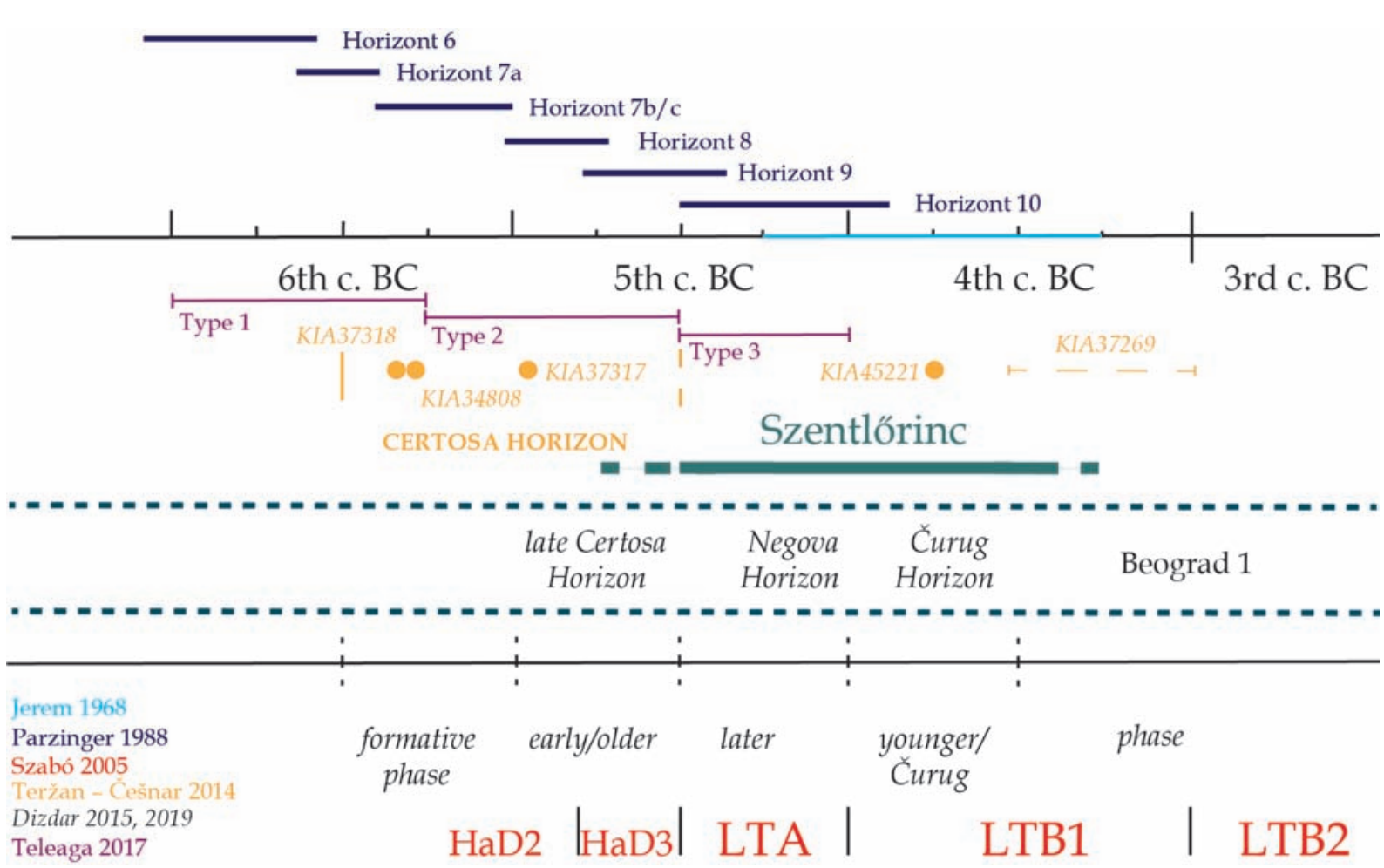

Fig. 32. The absolute chronological position of Szentlörinc in regard of JEREM 1968, PARzInGer 1989, Szabó 2005, Teržan - Češnar 2014, Dizdar 2015, Dizdar 2019 and Teleaga 2017. For the Radiocarbon dates, the MM values have been used if known, otherwise the GPP value has been projected. In the case of KIA45221 the median date was taken.

\section{Conclusion and Outlook}

We have to stress that on the basis of certain ceramic forms, there is a close connection between Szentlőrinc and Szajk - not only on geographical terms (the two sites lie in around 50 $\mathrm{km}$ distance from each other). It seems, that Szajk either begins where Szentlőrinc chronologically terminates or Szentlörinc is at least partly contemporary with the first phase of the settlement: note the Early La Tène-Scheme fibulae from graves 40, 63 and 65 and the sparse, but existing fibulae from the settlement. ${ }^{108}$ Beremend (in $55 \mathrm{~km}$ distance to the south of Szentlörinc, already mentioned) rounds up the (published, but not at all conclusive) knowledge we have from the area around Pécs, from the Late Hallstatt and Early La Téne period. These three sites constitute very important information on the transition late Hallstatt to Early La Tène and should be studied more in depth (there is only a preliminary publication of Szajk), reevaluated and fit into the context of the so-called Southeast Pannonian Late Hallstatt/Srem/ Syrmian or Osijek Group.

Furthermore, as an outlook it can be expressed that the concept of cultural distance (first employed on a larger scale by O. Nakoinz in 2013) can be applied to the material culture of the Srem group as a next step. Multivariate statistical analyses already standardize and abstract the archaeological material and thus formal similarities and dissimilarities will be 
possible to outline between macro- or microregion or even between sites or graves on the basis of their Typenspectra. ${ }^{109}$

Conclusively we can say that multivariate statistical analyses can by all means illuminate correlations and interdependencies which are not that transparent at first sight in our dataset, but we always have to reflect on their usefulness case-by-case. In addition, we always have to keep in mind that it falls upon the archaeologist to interpret the results.

\section{Acknowledgements}

I would like to express my gratitude towards Dr. Emilian Teleaga (Vorgeschichtliches Seminar, Philipps-Universität Marburg), to have given me this argument as topic for a seminar thesis. I also would like to thank Prof. Dr. Dr. Thomas Brenner and Dr. Jürgen Kluge (both from the Department of Geography, Philipps-Universität Marburg, Germany) who navigated me in the sea of multivariate statistics. The packages quantAAR and varnastats are being developed by the ISAAKiel, mainly by Clemens Schmid and Martin Hinz. The ${ }^{14} \mathrm{C}$ results in Fig. 28 have been processed with the online version of $\mathrm{OxCal} 4.3 .2$, on the basis of data presented in TERŽAN - ČEŠNAR 2014.

\section{References}

Aggarwal, R. - Ranganathan, P. 2016: Common pitfalls in statistical analysis: The use of correlation techniques. Perspectives in Clinical Research 7, 187-190.

Božič, D. 1981: Relativna kronologija mlazše železne dobe v jugoslovanskem podonavju. Arheološki Vestnik 32, 315-336.

Bronk Ramsey, C. 2009: Bayesian analysis of radiocarbon dates. Radiocarbon 51, 337-360.

Bronk Ramsey, C. 2017: Methods for Summarizing Radiocarbon Datasets. Radiocarbon 59, 1809-1833.

CArLson, D. L. 2017: Quantitative Methods in Archaeology Using R. Cambridge.

D'Enza, A. I. - Greenacre, M. 2012: Multiple Correspondence Analysis for the Quantification and Visualization of Large Categorical Data Sets. In: Di CAccio, A. et al. (eds): Advanced Statistical Methods for the Analysis of Large Data-Sets. Studies in Theoretical and Applied Statistics. Heidelberg, 453-463.

Dizdar, M. 2010: Kantharoi of autochtonous - "Pannonian" origin from the La Tène culture cemetery Zvonimirovo, Croatia. In: Berecki, S. (ed.): Iron Age Communities in the Carpathian Basin. Proceedings of the International Colloquium from Târgu Mureş, 9-11 October 2009. Cluj-Napoca, 297-307.

Dizdar, M. 2015: Late Hallsatt Female Grave from Belišće. A Group of Late Hallstatt Finds in the Lower Drava Valley. In: Gutjarhr, Chr. - Tiefgraber, G. (Hrsg.): Beiträge zur Hallstattzeit am Rande der Südostalpen. Akten des 2. Inernationalen Symposiums am 10. und 11. Juni 2010 in Wildon (Steiermark/Osterreich). Rahden/Westf., 45-60.

Dizdar, M. 2019: New Late Hallstatt Finds from the Vonkovci Region (Eastern Croatia): A Contribution to the Study of Impacts from the Balkans to the southeastern Carpathian Basin. In: FiLIPović, V. - Bulatović, A. - Kapuran, A. (eds): Zbornik radova u čast 80. g. života Rastka Vasića, Arheološki institut. Beograd, 319-343.

Dobiat, C. 1980: Das hallstattzeitliche Gräberfeld von Kleinklein und seine Keramik. Schild vom Steier. Beiträge zur Steierischen Vor- und Frühgeschichte und Münzkunde I. Graz.

109 This concept is being implemented in R during the MOIN Summer Schools (MOdelling Interaction). https:// gitlab.com/CRC1266-A2/moin 
Drennan, R. D. 2009: Statistics for Archaeologists. A Common Sense Approach. New York.

DuLAR, J. 2007: Pferdegräber nd Pferdebestattungen in der hallstattzeitlichen Doljensko-Gruppe. SITULA 44, 737-748.

Eggert, M. K. H. et al. 2012: Prähistorische Archäologie: Konzepte und Methoden. Tübingen.

Fletcher, M. - Lock, G. 2005: Digging Numbers. Elementary Statistics for Archaeologists. Second Edition. Oxford.

GarašAnin, M. 1973: Sremska grupa zapadnobalkanskog kompleksa. Praistorija Srbije II. Beograd, 651-655.

GÁti, Cs. 2014: On the Crossroads of Cultures. Cultural and Trade Connections of the site of Szajk in South Transdanubia in the sixth-fourth centuries BC. In: BERECKI, S. (ed): Iron Age Crafts and Craftsmen in the Carpathian Basin. Proceedings of the International Colloquium from Târgu Mureş, 10-13 October 2013. Târgu Mureş, 115-138.

Goldmann, K. 1979: (ed.) Die Seriation chronologischer Leitfunde der Bronzezeit Europas. Berliner Beiträge zur Vor- und Frühgeschichte. Neue Folge - Band 1, Berlin.

Greenacre, M. J. 1984: Theory and Applications of Corresponcence Analysis. London.

Greenacre, M. J. 1991: Interpreting multiple correspondence analysis. Applied Stochastic Models and Data Analysis 7, 195-210.

Greenacre, M. J. 2005: From Correspondence Analysis to Multiple and foint Correspondence Analysis. (Accessed at SSRN: https://ssrn.com/abstract=847664; DOI: http://dx.doi.org/10.2139/ssrn. 847664)

Greenacre, M. J. 2006: Tying up the loose ends in simple, multiple, joint correspondence analysis. Compstat - Proceedings in Computational Statistics 164-187.

Greenacre, M. J. - Primicero, R. 2013: Correspondence Analysis. In: Greenacre, M. J., - Primicero, R.: Multivariate Analysis of Ecological Data. Barcelona, 165-176.

Ihm, P. - Lüning, J. - Zimmermann, A. 1978: Statistik in der Archäologie. Probleme der Anwendung, allgemeine Methoden, Seriation und Klassifikation. Archaeo-Physika 9, Bonn.

Jerem, E. 1968: The Late Iron Age Cemetery of Szentlőrinc. Acta Archaeologica Academiae Scientiarum Hungaricae 20, 159-209.

Jerem, E. 1973: Zur Geschichte der späten Eisenzeit in Transdanubien. Späteisenzeitliche Grabfunde von Beremend (Komitat Baranya). Acta Archaeologica Academiae Scientiarum Hungaricae 25, 65-86.

KemenczeI, T. 2009: Studien zu den Denkmälern skytisch geprägter Alföld Gruppe. Inventaria Praehistorica Hungariae, Budapest.

Leyer, I. - Wesche, K. 2006: Multivariate Statistik in der Ökologie. Berlin-Heidelberg.

Ljustina, M. 2010: The Late Hallstatt Communities in the Serbian Part of the Danube Basin. In: BerecKI, S. (ed.): Iron Age Communities in the Carpathian Basin. Proceedings of the International Colloquium from Târgu Mureş, 9-11 October 2009. Târgu Mureş, 59-78.

Medović, P. 2002: Bestattungen in der älteren Eisenzeit im Gebiet der Bosut-Gruppe. In: Bojovic, N. Vasić, M. (Eds): Sahranjivanje u bronzano i gvozdenog doba. Sympozijum Čačak 2002, September 4-8. Čačak, 101-106.

MetZner-Nebelsick, C. 2002: Der "Thrako-Kimmerische" Formenkreis aus der Sicht der Urnenfelderund Hallstattzeit im Südöstlichen Pannonien I-II. Vorgeschichtliche Forschungen 23, Rhaden/ Westf.

NAKoInz, O. 2005: Studien zur räumlichen Abgrenzung und Strukturierung der älteren HunsrückEifel-Kultur. Universitätsforschungen zur prähistorischen Archäologie 118, Bonn.

Nenadić, O. - Greenacre, M. J. 2007: Correspondence Analysis in R, with Two- and Three-dimensional Graphics: The ca package. Journal of Statistical Software 20/3, 1-13. 
Onsanen, J. 2014: Cluster Analysis: Tutorial with R (January, 26, 2014). http://cc.oulu.fi/ jarioksa/opetus/metodi/sessio3.pdf

OKsanen, J. 2015: Multivariate Analysis of Ecological Communities in R: vegan tutorial (June 10, 2015). http://cc.oulu.fi/ jarioksa/opetus/metodi/vegantutor.pdf

PARZINGer, H. 1988: Chronologie der Späthallstatt- und Frühlatène-Zeit. Studien zu Fundgruppen zwischen Mosel und Save. Quellen und forschungen zur prähistorischen unsd provinzialrömischen Archäologie 4, Winheim.

Reimer, P. J. et al. 2013: IntCal13 and Marine13 Radiocarbon Age Calibration Curves 0-50,000 Years cal BP. Radiocarbon, 55, 1869-1887.

Schwellnuss, F. 2011: Die Siedlung von Sopron-Krautacker (Westungarn) in der Hallstatt- und frühen Latènezeit. Archäologisches Korrespondenzblatt 41, 359-373.

Siegmund, F. 2015: Gewußt wie: Praxisleitfaden Seriation und Korrespondenzanalyse in der Archäologie. BoD Nordersted.

Stöllner, Th. 2002: Die Hallstattzeit und der Beginn der Latènezeit im Inn-Salzach-Raum. Archäologie in Salzburg, Band 3/I-II. Salzburg.

TANKó, K. 2005: 'Horn-handled' bowls of the Central Europe Iron Age. In: Dobrańska, H. - Megaw, V. Poleska, P. (eds): Celts on the Margin-Studies in European Cultural Interaction. $7^{\text {th }}$ Century BC $1^{\text {st }}$ Century AD. Dedicated to Zenon Woźniak. Institute of Archaeology and Ethnology of the Polish Academy of Sciences. Kraków, 153-162.

Teleaga, E. 2017: Studien zu den späthallstattzeitlichen Wagengräbern des Karpatenbecken. Studien zur eisenzeitlichen Archäologie Thrakiens 2/I, Rhaden/Westf.

TeržAn, B. 1976: Certoška Fibula. Arheološki Vestnik 26, 317-536.

TeržAn, B. - Češnar, M. 2014: Absolute Dating of the Bronze and Iron Ages in Slovenia. Catalogi et Monographiae 40, Ljubljana.

Werner, W. M. 1988: Eisenzeitliche Trensen an der unteren und mittleren Donau. Prähistorische Bronzefunde 16/4, München.

\section{Computational resoruces}

\section{OxCal}

Bronk Ramsey 2009; Reimer et al. 2013; Bronk Ramsey 2017.

https://c14.arch.ox.ac.uk/oxcal.html

\section{$\boldsymbol{R}$}

R Core Team (2019). R: A language and environment for statistical computing. R Foundation for Statistical Computing, Vienna, Austria. URL https://www.R-project.org/.

ca

NENADIĆ - GREENACRE 2007

https://cran.r-project.org/web/packages/ca/index.html

vegan

OKSANEN 2014; OKSANEN 2015.

Oksanen, J. - Blanchet, F. G. - Friendly, M. - Kindt, R. - Legendre, P. - McGlinn, D. - Minchin, P. R. O'Hara R. B. - Simpson, G. L. - Solymos, P. - Henry, M. - Stevens, H. - Szoecs, E. - Wagner, H. 2019: vegan: Community Ecology Package. $R$ package version 2.5-5. https://CRAN.R-project.org/package= vegan 
quantAAR (not published on CRAN yet)

https://github.com/ISAAKiel/quantAAR

varnastats (not published on CRAN yet)

https://github.com/nevrome/varnastats

Licence: https://github.com/nevrome/varnastats/blob/master/LICENSE 
41.2

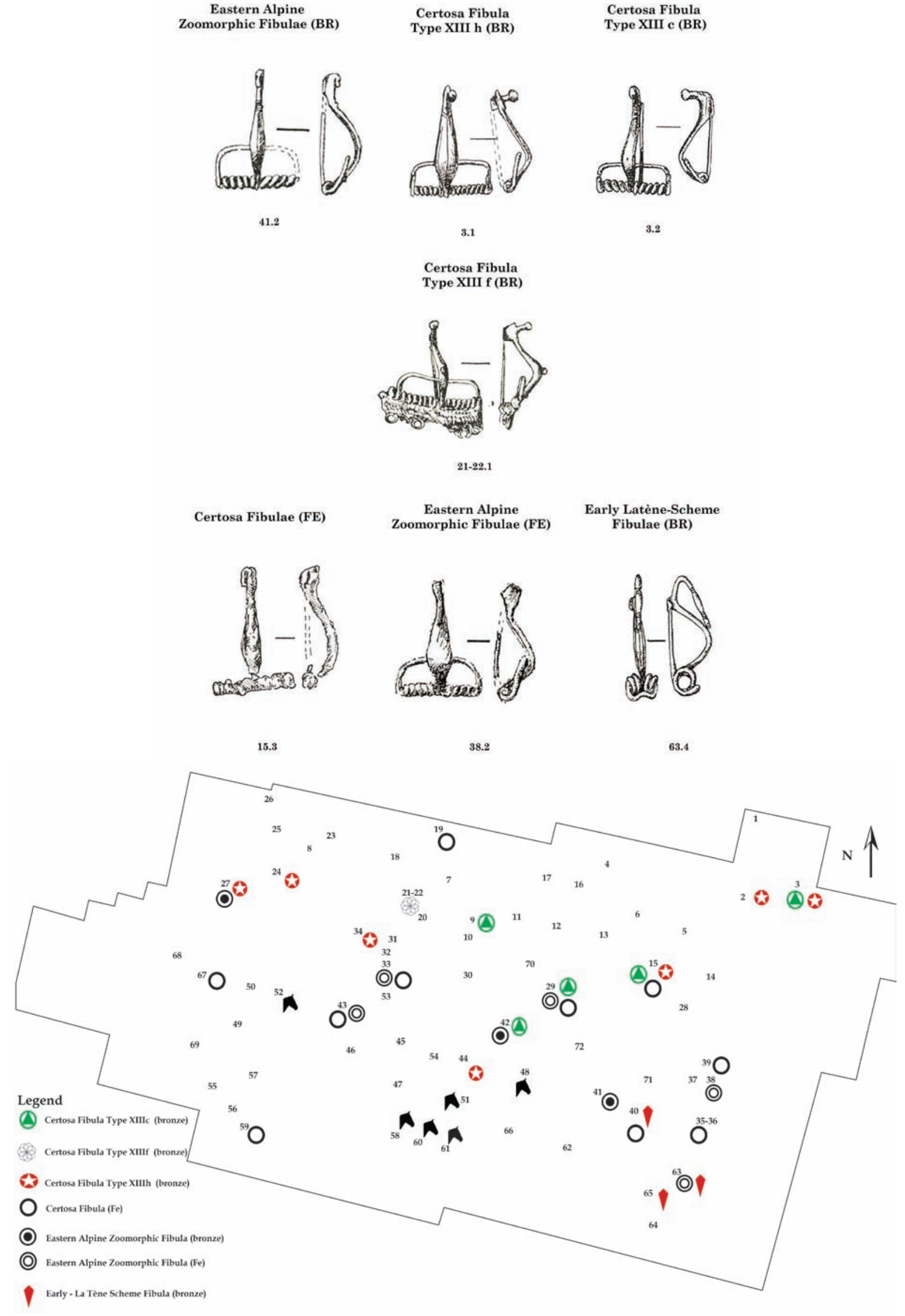

$$
\begin{aligned}
& \text { Certosa Fibula } \\
& \text { Type XIII h (BR) }
\end{aligned}
$$

Certosa Fibula

Type XIII c (BR)

Fig. 33. Distribution of the fibulae types in Szentlörinc. 
Biconical one-handled mug

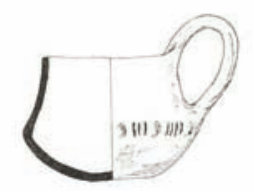

20.3

Spherical calotte

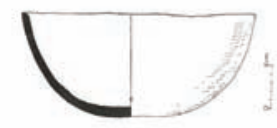

26.2

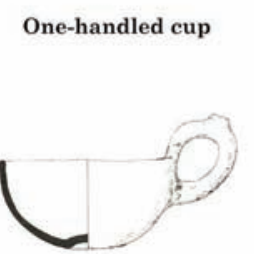

20.2

Biconical Pot

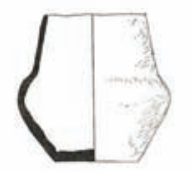

$35-36.1$
Biconical two-handled mug "Pannonian Kantharoi"

Spherical bowl

with Omphalos

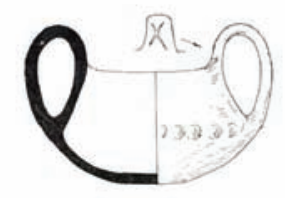

13.1

Bowl with retracted rim

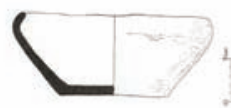

26.1

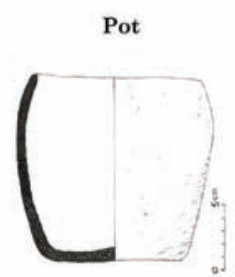

38.1

Anthropomorphic vessel

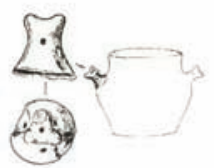

46.3
Spherical bowl with Omphalos \& retracted rim

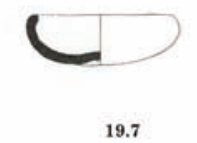

Biconical pot with knob handle

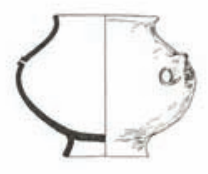

19.4

One handled mug

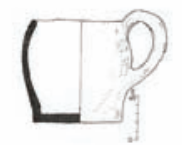

19.5

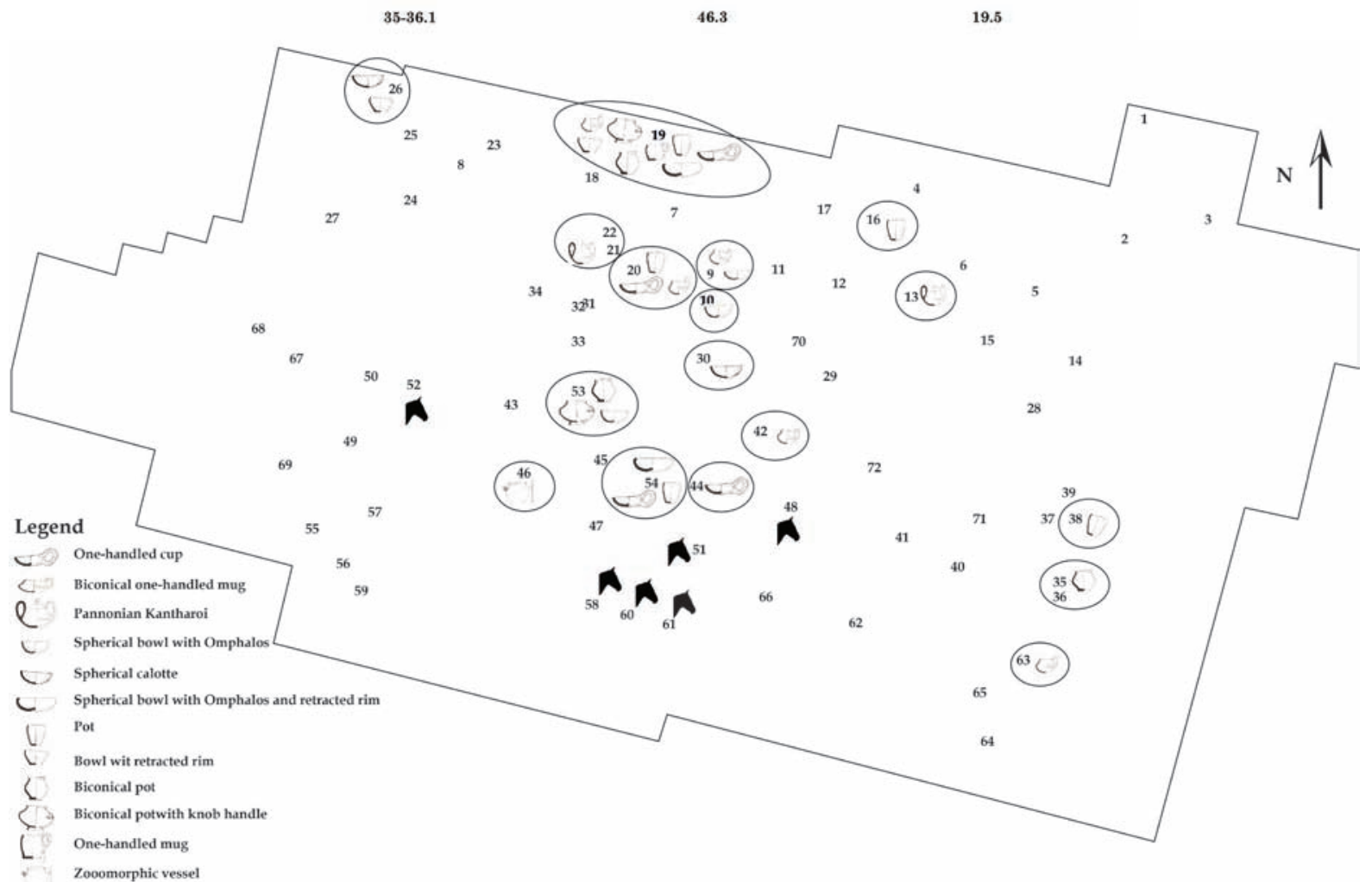

Fig. 34. Distribution of the pottery in Szentlőrinc. 


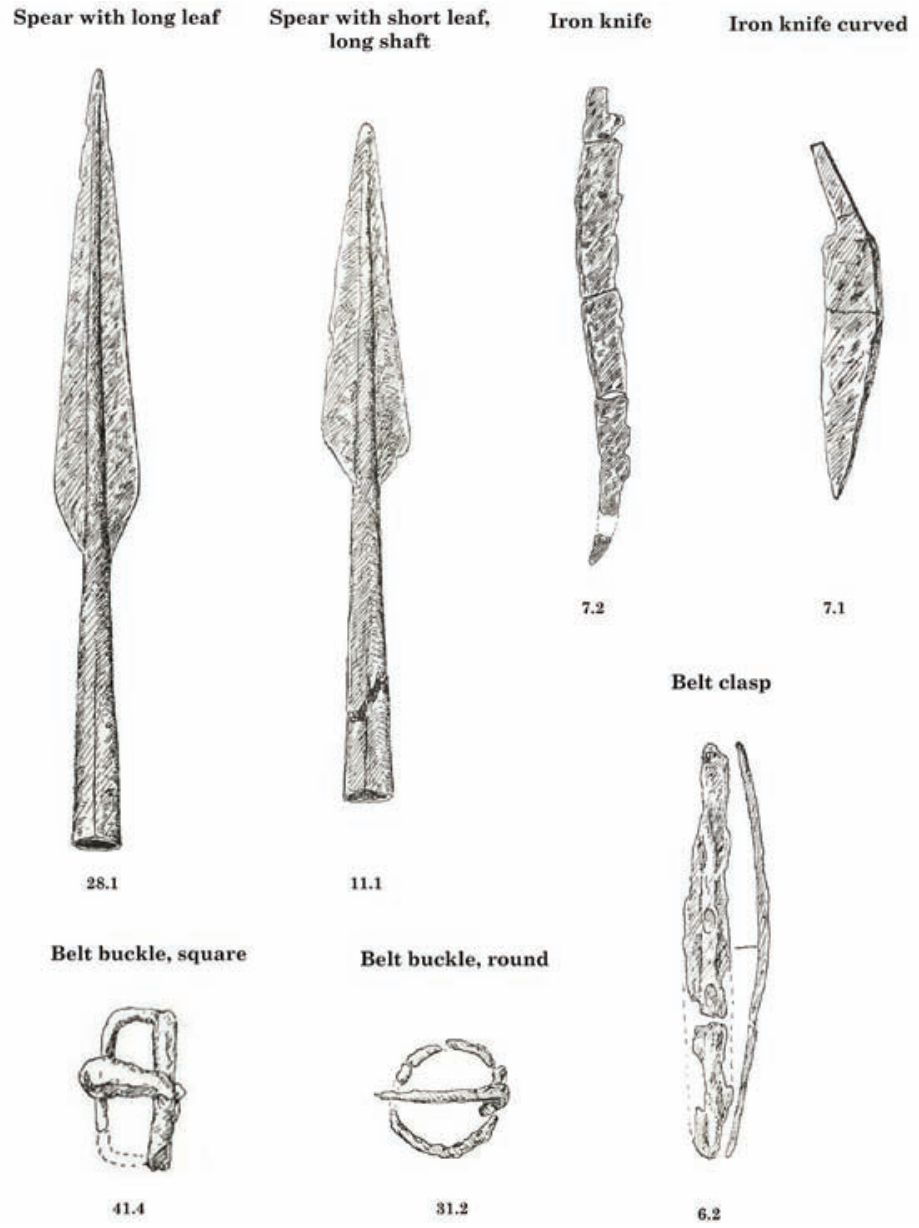

Fig. 35. Spear, knife and belt buckle types found in Szentlőrinc.

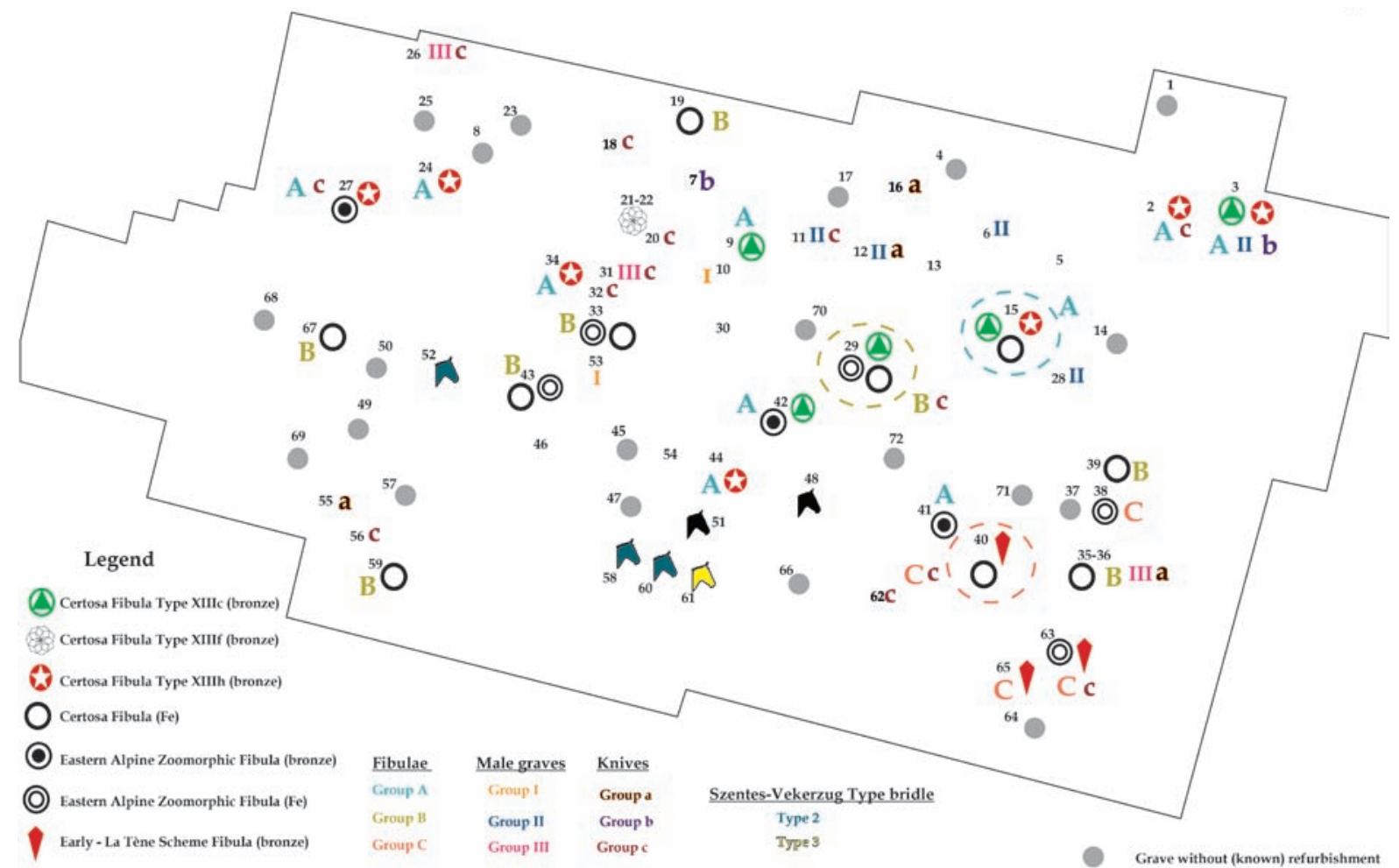

Fig. 36. The relative chronology of Szentlörinc. 


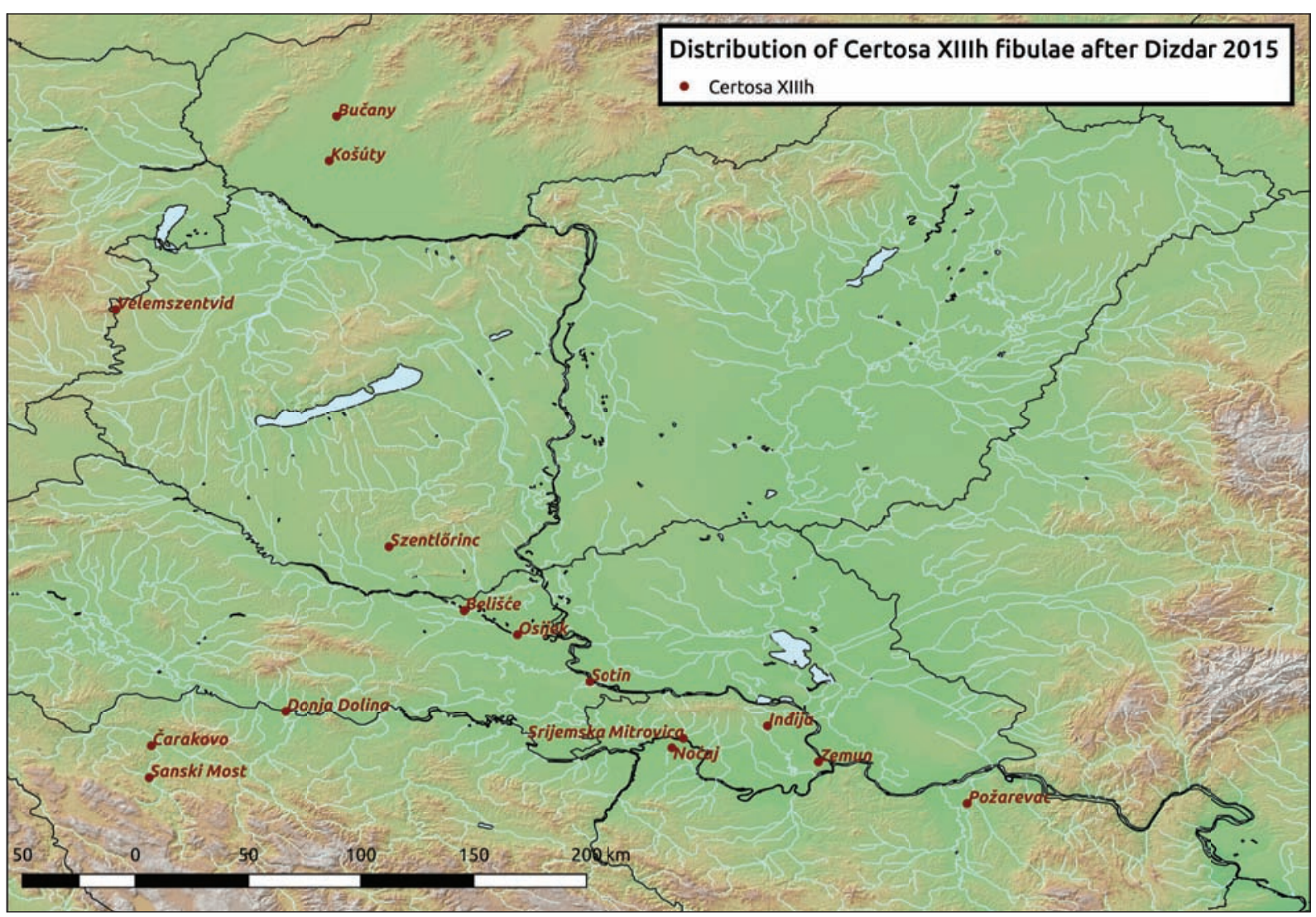

Fig. 37. Distribution of Čertosa XIIIh fibulae after Dizdar 2015.

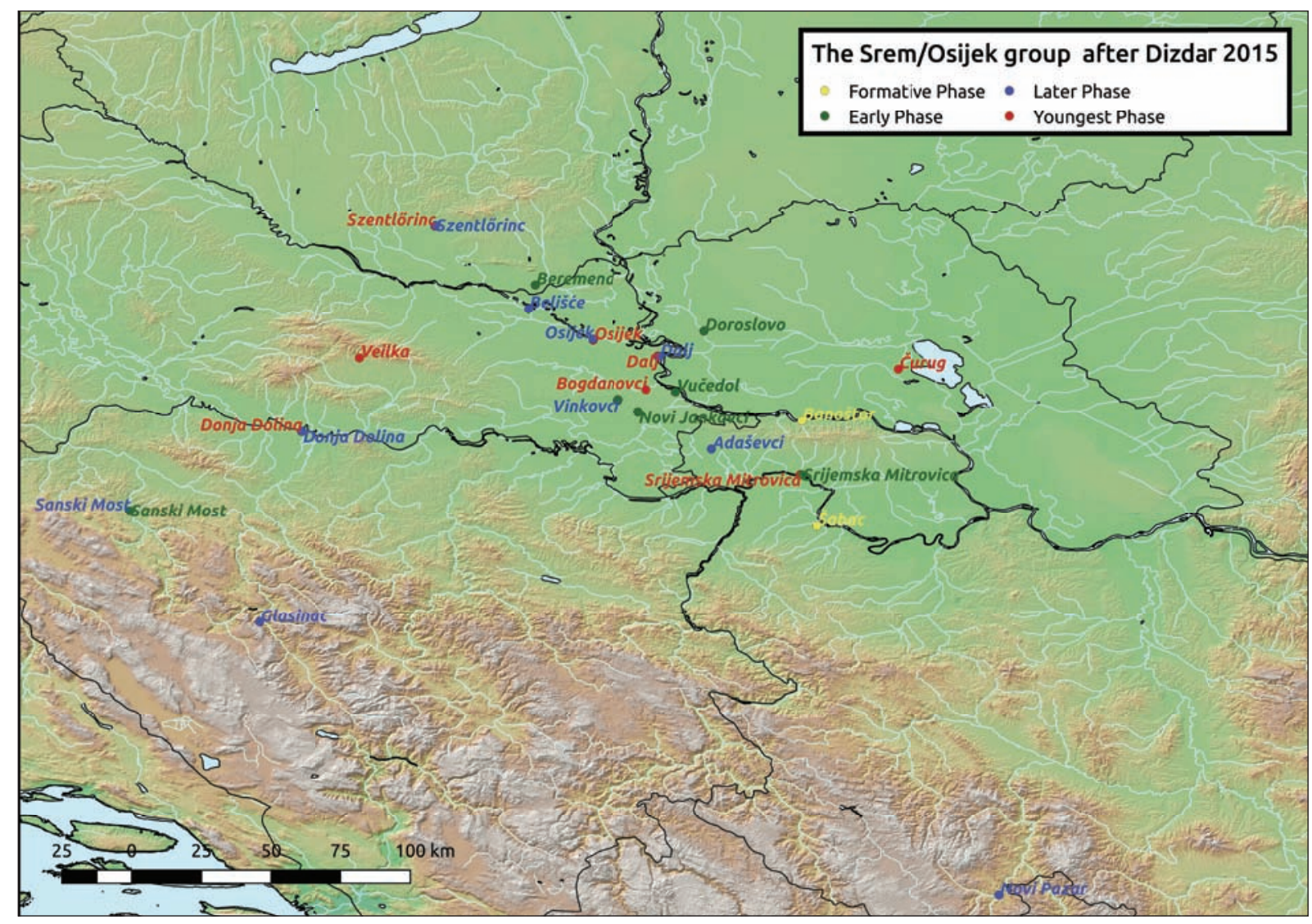

Fig. 38. The Srem/Osijek group after Dizdar 2015. 
Tab. 1. Diagnostic information of the graves in Szentlörinc used in this study.

\begin{tabular}{|c|c|c|c|c|c|c|c|c|c|c|c|}
\hline 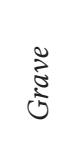 & 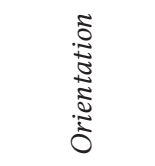 & 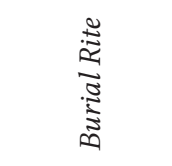 & ڤँ & $\stackrel{\circ}{\square}$ & 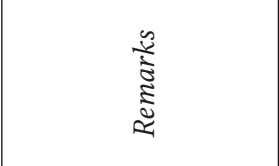 & 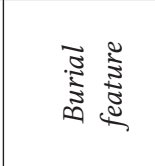 & 芯 & 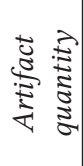 & 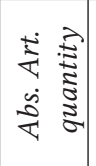 & 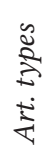 & 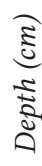 \\
\hline 1 & $\mathrm{E}-\mathrm{W} / \mathrm{W}-\mathrm{E}$ & unknown & $?$ & infans & no grave goods & unknown & $?$ & 0 & 0 & 0 & $?$ \\
\hline 2 & W-E & inhumation & q & $30-40 \mathrm{Y}$ & (6 glass beads) & $\begin{array}{l}\text { extended } \\
\text { skeleton }\end{array}$ & $?$ & 3 & 9 & 3 & $?$ \\
\hline 3 & $\mathrm{E}-\mathrm{W} / \mathrm{W}-\mathrm{E}$ & inhumation & $\begin{array}{l}\varphi \\
0 \\
0\end{array}$ & $30-55 \mathrm{Y}$ & double grave & $\begin{array}{l}\text { extended } \\
\text { skeleton }\end{array}$ & $?$ & 7 & 7 & 6 & $?$ \\
\hline 4 & W-E & inhumation & q & $40-45 \mathrm{Y}$ & no grave goods & $\begin{array}{l}\text { extended } \\
\text { skeleton }\end{array}$ & $?$ & 0 & 0 & 0 & $?$ \\
\hline 5 & W-E & inhumation & $?$ & $?$ & only 1 object & $\begin{array}{l}\text { stone } \\
\text { pavement }\end{array}$ & disturbed & 1 & 1 & 1 & 60 \\
\hline 6 & W-E & inhumation & 0 & $?$ & bad preservation & $\begin{array}{l}\text { extended } \\
\text { skeleton }\end{array}$ & $?$ & 2 & 2 & 2 & 65 \\
\hline 7 & W-E & inhumation & 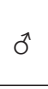 & $?$ & bad preservation & \begin{tabular}{|l} 
stone \\
pavement
\end{tabular} & disturbed & 2 & 2 & 2 & 90 \\
\hline 8 & E-W & inhumation & $?$ & $?$ & bad preservation & $\begin{array}{l}\text { extended } \\
\text { skeleton }\end{array}$ & disturbed & 0 & 0 & 0 & 70 \\
\hline 9 & $\mathrm{~N}-\mathrm{S}$ & inhumation & q & $7-10 \mathrm{Y}$ & $\begin{array}{l}\text { bad preservation, } \\
\text { (3 glass beads) }\end{array}$ & $\begin{array}{l}\text { extended } \\
\text { skeleton }\end{array}$ & undisturbed & 7 & 9 & 6 & 60 \\
\hline 10 & - & cremation & $0^{\pi}$ & $?$ & $\begin{array}{l}\text { male refurbishment, } \\
\text { ( } 5 \text { iron buttons) }\end{array}$ & $\begin{array}{l}\text { strewn } \\
\text { ashes }\end{array}$ & undisturbed & 2 & 6 & 2 & 50 \\
\hline 11 & W-E & cenotaph & $?$ & $?$ & spear \& knife & cenotaph & disturbed & 2 & 2 & 2 & 45 \\
\hline 12 & W-E & inhumation & $0^{*}$ & $50-55 \mathrm{Y}$ & male refurbishment & $\begin{array}{l}\text { extended } \\
\text { skeleton }\end{array}$ & undisturbed & 4 & 4 & 3 & 50 \\
\hline 13 & E-W & inhumation & q & $25-30 \mathrm{Y}$ & bad preservation & $\begin{array}{l}\text { extended } \\
\text { skeleton }\end{array}$ & $?$ & 1 & 1 & 1 & 30 \\
\hline 14 & W-E & inhumation & $0^{\pi}$ & $6-8 \mathrm{Y}$ & no grave goods & $\begin{array}{l}\text { extended } \\
\text { skeleton }\end{array}$ & disturbed & 0 & 0 & 0 & 13 \\
\hline 15 & NW-SE & inhumation & q & $7-8 \mathrm{Y}$ & $\begin{array}{l}\text { (1 glass, } 7 \text { amber } \\
\text { beads })\end{array}$ & $\begin{array}{l}\text { extended } \\
\text { skeleton }\end{array}$ & disturbed & 8 & 14 & 3 & 40 \\
\hline 16 & SW-NE & inhumation & q & $40-45 \mathrm{Y}$ & little refurbishment & $\begin{array}{l}\text { extended } \\
\text { skeleton }\end{array}$ & disturbed & 2 & 2 & 2 & 80 \\
\hline 17 & NW-SE & inhumation & $0^{\pi}$ & $35-40 \mathrm{Y}$ & no gave goods & $\begin{array}{l}\text { extended } \\
\text { skeleton }\end{array}$ & $?$ & 0 & 0 & 0 & 70 \\
\hline 18 & NW-SE & inhumation & $\sigma^{\lambda}$ & $70 \mathrm{Y}$ & spindle whorl & $\begin{array}{l}\text { stone } \\
\text { pavement }\end{array}$ & disturbed & 2 & 2 & 2 & 90 \\
\hline 19 & - & cenotaph & q & $?$ & (14 glass beads) & cenotaph & $?$ & 11 & 25 & 11 & 80 \\
\hline 20 & SE-NW & inhumation & $?$ & $?$ & $\begin{array}{l}\text { no sex specific } \\
\text { goods }\end{array}$ & $\begin{array}{l}\text { extended } \\
\text { skeleton }\end{array}$ & disturbed & 5 & 5 & 5 & 55 \\
\hline $21-22$ & E-W & inhumation & $\begin{array}{l}\uparrow \\
\wp \\
\end{array}$ & $25-30 \mathrm{Y}$ & $\begin{array}{l}\text { double gr ave, } \\
(10 \text { amber beads) }\end{array}$ & $\begin{array}{l}\text { extended } \\
\text { skeleton }\end{array}$ & disturbed & 3 & 12 & 1 & 80 \\
\hline 23 & W-E & inhumation & $?$ & $?$ & no grave goods & $\begin{array}{l}\text { extended } \\
\text { skeleton }\end{array}$ & disturbed & 0 & 0 & 0 & 80 \\
\hline 24 & E-W & cremation & q & $?$ & bustum? & \begin{tabular}{|l} 
stone \\
pavement
\end{tabular} & undisturbed & 1 & 1 & 1 & 45 \\
\hline 25 & W-E & inhumation & q & $50 \mathrm{Y}$ & $\begin{array}{l}\text { bad preservation, } \\
\text { no grave goods }\end{array}$ & $\begin{array}{l}\text { extended } \\
\text { skeleton }\end{array}$ & disturbed & 0 & 0 & 0 & 75 \\
\hline 26 & SW-NE & inhumation & $0^{\pi}$ & $45 \mathrm{Y}$ & male refurbishment & $\begin{array}{l}\text { extended } \\
\text { skeleton }\end{array}$ & undisturbed & 6 & 6 & 6 & 90 \\
\hline
\end{tabular}


The case study of the Early La Tène Cemetery of Szentlörinc

\begin{tabular}{|c|c|c|c|c|c|c|c|c|c|c|c|}
\hline 27 & NW-SE & inhumation & q & $50 \mathrm{Y}$ & $\begin{array}{l}\text { female } \\
\text { refurbishment }\end{array}$ & $\begin{array}{l}\text { extended } \\
\text { skeleton }\end{array}$ & disturbed & 5 & 5 & 5 & 55 \\
\hline 28 & $\mathrm{~W}-\mathrm{E}$ & inhumation & $\widehat{0}$ & $50 \mathrm{Y}$ & bad preservation & $\begin{array}{l}\text { extended } \\
\text { skeleton }\end{array}$ & disturbed & 4 & 4 & 4 & 37 \\
\hline 29 & W-E & inhumation & Q & $50 \mathrm{Y}$ & bioturbation & $\begin{array}{l}\text { extended } \\
\text { skeleton }\end{array}$ & disturbed & 7 & 37 & 6 & 70 \\
\hline 30 & $\mathrm{~W}-\mathrm{E}$ & inhumation & o & $40 \mathrm{Y}$ & awl & $\begin{array}{l}\text { extended } \\
\text { skeleton }\end{array}$ & disturbed & 2 & 2 & 2 & 75 \\
\hline 31 & NW-SE & inhumation & $\pi$ & $40 \mathrm{Y}$ & iron arrow-head & $\begin{array}{l}\text { extended } \\
\text { skeleton }\end{array}$ & disturbed & 5 & 5 & 4 & 65 \\
\hline 32 & W-E & inhumation & 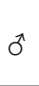 & $60-70 \mathrm{Y}$ & bronze pin & $\begin{array}{l}\text { extended } \\
\text { skeleton }\end{array}$ & $?$ & 2 & 2 & 1 & 75 \\
\hline 33 & W-E & inhumation & o & $40-50 \mathrm{Y}$ & $\begin{array}{l}\text { (23 glass }+2 \text { amber } \\
\text { beads })\end{array}$ & $\begin{array}{l}\text { extended } \\
\text { skeleton }\end{array}$ & $?$ & 7 & 30 & 5 & 80 \\
\hline 34 & - & cremation & o & $4-5 \mathrm{Y}$ & $\begin{array}{l}\text { Bustum? ( } 3 \text { glass + } \\
18 \text { amber beads) }\end{array}$ & $\begin{array}{l}\text { strewn } \\
\text { ashes }\end{array}$ & undisturbed & 9 & 28 & 5 & 30 \\
\hline $35-36$ & W-E & inhumation & $\begin{array}{l}\text { क } \\
0\end{array}$ & $\begin{array}{l}40-45 \mathrm{Y} \\
10-12 \mathrm{Y}\end{array}$ & $\begin{array}{l}\text { double grave } \\
\text { (12 iron buttons) }\end{array}$ & $\begin{array}{l}\text { extended } \\
\text { skeleton }\end{array}$ & disturbed? & 5 & 16 & 3 & 62 \\
\hline 37 & $?$ & inhumation & O & $50 \mathrm{Y}$ & no grave goods & $\begin{array}{l}\text { extended } \\
\text { skeleton }\end{array}$ & disturbed & 0 & 0 & 0 & 62 \\
\hline 38 & $\mathrm{~S}-\mathrm{N}$ & inhumation & o & $25 \mathrm{Y}$ & little refurbishment & $\begin{array}{l}\text { extended } \\
\text { skeleton }\end{array}$ & disturbed & 2 & 2 & 2 & 74 \\
\hline 39 & $?$ & inhumation & o & $30-35 \mathrm{Y}$ & $\begin{array}{l}\text { Female } \\
\text { refurbishment }\end{array}$ & $\begin{array}{l}\text { extended } \\
\text { skeleton }\end{array}$ & disturbed & 2 & 2 & 2 & 60 \\
\hline 40 & $\begin{array}{l}? \\
?\end{array}$ & $\begin{array}{l}\text { inhumation } \\
\text { cremation }\end{array}$ & $\begin{array}{l}\text { } \\
?\end{array}$ & $\begin{array}{c}30-35 \mathrm{Y} \\
30 \mathrm{Y}\end{array}$ & $\begin{array}{l}\text { double grave } \\
\text { (18 amber beads) }\end{array}$ & $\begin{array}{l}\text { extended } \\
\text { skeleton }\end{array}$ & disturbed & 7 & 24 & 7 & 75 \\
\hline 41 & $?$ & inhumation & o & $17-25 \mathrm{Y}$ & $\begin{array}{l}(46 \text { amber }+1 \text { silver } \\
\text { beads) }\end{array}$ & $\begin{array}{l}\text { extended } \\
\text { skeleton }\end{array}$ & disturbed & 4 & 49 & 4 & 80 \\
\hline 42 & $\mathrm{~S}-\mathrm{N}$ & $\begin{array}{l}\text { inhumation } \\
\text { cremation }\end{array}$ & $\begin{array}{l}\text { o } \\
\text { ô }\end{array}$ & $\begin{array}{c}35-40 \mathrm{Y} \\
3 \mathrm{Y}\end{array}$ & $\begin{array}{l}\text { double graave } \\
\text { (64 glass beads) }\end{array}$ & $\begin{array}{l}\text { extended } \\
\text { skeleton } \\
\text { strewn } \\
\text { ashes }\end{array}$ & disturbed & 4 & 67 & 4 & 78 \\
\hline 43 & W-E & inhumation & o & $17-20 \mathrm{Y}$ & (9 amber beads) & $\begin{array}{l}\text { extended } \\
\text { skeleton }\end{array}$ & disturbed & 3 & 11 & 3 & 75 \\
\hline 44 & $\mathrm{E}-\mathrm{W} / \mathrm{W}-\mathrm{E}$ & cremation & o & $1-5 \mathrm{Y}$ & $\begin{array}{l}\text { (3 glass, } 16 \text { amber, } \\
1 \text { silver wire bead) }\end{array}$ & $\begin{array}{l}\text { strewn } \\
\text { ashes } \\
\text { stone } \\
\text { pavement }\end{array}$ & undisturbed & 5 & 23 & 4 & 30 \\
\hline 45 & W-E & inhumation & o & $2-4 \mathrm{Y}$ & no gave goods & $\begin{array}{l}\text { stone } \\
\text { pavement }\end{array}$ & disturbed? & 0 & 0 & 0 & 22 \\
\hline 46 & - & cremation & o & $?$ & zoomorphic vessel & $\begin{array}{l}\text { stone } \\
\text { pavement }\end{array}$ & disturbed & 2 & 2 & 1 & 30 \\
\hline 47 & $\mathrm{E}-\mathrm{W}$ & inhumation & $\widehat{0}$ & $30-40 \mathrm{Y}$ & only 1 Silex & $\begin{array}{l}\text { extended } \\
\text { skeleton }\end{array}$ & disturbed? & 0 & 0 & 0 & 75 \\
\hline 48 & $\mathrm{E}-\mathrm{W}$ & $\begin{array}{l}\text { Horse } \\
\text { burial }\end{array}$ & - & maturus & no grave goods & $\begin{array}{l}\text { skull \& } \\
\text { extremities }\end{array}$ & undisturbed & 0 & 0 & 0 & 60 \\
\hline 49 & $\mathrm{~S}-\mathrm{N}$ & inhumation & ठ & $30-40 \mathrm{Y}$ & no grave goods & $\begin{array}{l}\text { extended } \\
\text { skeleton }\end{array}$ & disturbed? & 0 & 0 & 0 & 50 \\
\hline 50 & $E-W$ & inhumation & $\widehat{0}$ & $40 \mathrm{Y}$ & no grave goods & $\begin{array}{l}\text { extended } \\
\text { skeleton }\end{array}$ & disturbed? & 0 & 0 & 0 & 75 \\
\hline 51 & $\mathrm{E}-\mathrm{W}$ & $\begin{array}{l}\text { Horse } \\
\text { burial }\end{array}$ & - & senilis & no grave goods & $\begin{array}{l}\text { skull \& } \\
\text { extremities }\end{array}$ & undisturbed & 0 & 0 & 0 & 55 \\
\hline
\end{tabular}




\begin{tabular}{|c|c|c|c|c|c|c|c|c|c|c|c|}
\hline 52 & NE-SW & $\begin{array}{l}\text { Horse } \\
\text { burial }\end{array}$ & - & adultus & $\begin{array}{l}\text { Iron horse-bit of the } \\
\text { Vekerzug-type } \\
3 \text { horses }\end{array}$ & $\begin{array}{l}\text { stone } \\
\text { pavement }\end{array}$ & disturbed & 10 & 62 & 8 & 45 \\
\hline 53 & $?$ & inhumation & $0^{t}$ & $15 \mathrm{Y}$ & only pottery & $\begin{array}{l}\text { extended } \\
\text { skeleton }\end{array}$ & disturbed & 4 & 4 & 4 & 75 \\
\hline 54 & $?$ & cenotaph & $?$ & $?$ & Pottery, horsebones & cenotaph & disturbed? & 4 & 4 & 3 & 50 \\
\hline 55 & - & cremation & $0^{\pi}$ & $?$ & fragments of a knife & $\begin{array}{l}\text { strewn } \\
\text { ashes }\end{array}$ & disturbed & 1 & 1 & 1 & 50 \\
\hline 56 & W-E & inhumation & $0^{2}$ & infans & 1 knife w c b & $\begin{array}{l}\text { extended } \\
\text { skeleton }\end{array}$ & disturbed & 1 & 1 & 1 & 65 \\
\hline 57 & W-E & inhumation & q & $45 \mathrm{Y}$ & $\begin{array}{l}\text { fragments of a } \\
\text { vessel }\end{array}$ & $\begin{array}{l}\text { extended } \\
\text { skeleton }\end{array}$ & disturbed & 1 & 1 & 1 & 100 \\
\hline 58 & SW-NE & $\begin{array}{l}\text { Horse } \\
\text { burial }\end{array}$ & - & $?$ & $\begin{array}{l}\text { Iron hrose bit of the } \\
\text { Vekerzug-Type }\end{array}$ & \begin{tabular}{|l} 
skull \& \\
extremities
\end{tabular} & undisturbed & 6 & 6 & 6 & 70 \\
\hline 59 & $?$ & inhumation & q & $6-7 \mathrm{Y}$ & bad preservation & $\begin{array}{l}\text { extended } \\
\text { skeleton }\end{array}$ & disturbed? & 4 & 11 & 3 & 80 \\
\hline 60 & $\mathrm{~S}-\mathrm{N}$ & $\begin{array}{l}\text { Horse } \\
\text { burial }\end{array}$ & - & $?$ & $\begin{array}{l}\text { Iron hrose bit of the } \\
\text { Vekerzug-Type }\end{array}$ & $\begin{array}{l}\text { skull \& } \\
\text { extremities }\end{array}$ & disturbed & 2 & 2 & 2 & 75 \\
\hline 61 & $\mathrm{~S}-\mathrm{N}$ & $\begin{array}{l}\text { Horse } \\
\text { burial }\end{array}$ & - & $?$ & $\begin{array}{l}\text { Iron hrose bit of the } \\
\text { Vekerzug-Type }\end{array}$ & extremities & undisturbed & 3 & 41 & 3 & 80 \\
\hline 62 & $\mathrm{~N}-\mathrm{S}$ & inhumation & $0^{t}$ & $50 \mathrm{Y}$ & iron knife & $\begin{array}{l}\text { extended } \\
\text { skeleton }\end{array}$ & disturbed? & 1 & 1 & 1 & 70 \\
\hline 63 & W-E & inhumation & $0^{2}$ & $40 \mathrm{Y}$ & burnt layer on top & $\begin{array}{l}\text { extended } \\
\text { skeleton }\end{array}$ & undisturbed & 4 & 4 & 4 & 80 \\
\hline 64 & W-E & inhumation & q & $45-50 \mathrm{Y}$ & no grave goods & $\begin{array}{l}\text { extended } \\
\text { skeleton }\end{array}$ & disturbed & 0 & 0 & 0 & 65 \\
\hline 65 & E-W & inhumation & q & $55 \mathrm{~J}$ & (9 glass beads) & $\begin{array}{l}\text { extended } \\
\text { skeleton }\end{array}$ & disturbed & 3 & 11 & 2 & 70 \\
\hline 66 & - & cremation? & $?$ & adultus & no grave goods & $\begin{array}{l}\text { strewn } \\
\text { ashes }\end{array}$ & disturbed? & 0 & 0 & 0 & 56 \\
\hline 67 & - & $\begin{array}{l}\text { inhumation } \\
\text { cremation? }\end{array}$ & q & $\begin{array}{c}45 \mathrm{Y} \\
8 \mathrm{Y}, 5 \mathrm{Y}\end{array}$ & $\begin{array}{l}\text { triple grave } \\
\text { (33 amber, } 16 \text { glass } \\
\text { beads) }\end{array}$ & $\begin{array}{l}\text { extended } \\
\text { skeleton } \\
\text { strewn } \\
\text { ashes } \\
\end{array}$ & disturbed & 8 & 57 & 6 & 57 \\
\hline 68 & - & cremation? & $?$ & $?$ & little refurbishment & $\begin{array}{l}\text { strewn } \\
\text { ashes }\end{array}$ & disturbed & 1 & 1 & 1 & 50 \\
\hline 69 & $\mathrm{E}-\mathrm{W} / \mathrm{W}-\mathrm{E}$ & cenotaph & $?$ & $?$ & no grave goods & $\begin{array}{l}\text { cenotaph } \\
\text { stone } \\
\text { pavement } \\
\end{array}$ & disturbed? & 0 & 0 & 0 & 55 \\
\hline 70 & $?$ & inhumation & $0^{\pi}$ & $40 \mathrm{Y}$ & no grave goods & $\begin{array}{l}\text { extended } \\
\text { skeleton }\end{array}$ & disturbed & 0 & 0 & 0 & 50 \\
\hline 71 & $?$ & inhumation & $0^{\pi}$ & $7-8 \mathrm{Y}$ & no grave goods & $\begin{array}{l}\text { extended } \\
\text { skeleton }\end{array}$ & disturbed & 0 & 0 & 0 & 40 \\
\hline 72 & $?$ & inhumation & o & $35 \mathrm{Y}$ & no grave goods & $\begin{array}{l}\text { extended } \\
\text { skeleton }\end{array}$ & disturbed & 0 & 0 & 0 & 45 \\
\hline
\end{tabular}

Artifact quantity $=$ only the types of artifacts

Absolute Artifact Quantity = all artifacts in the graves

Artifact Types $=$ the different artifact types which can be used statisticly; graves with 0 and 1 are left out from the multivariate statistical analysis

„Special“ finds: G15 Dog tooth; G21-22 Kantharos; G35-36 Kantharos; G31 Arrowhead (iron); G32 Needle (bronze); G34 Sceptrum (bronze); G46 Zoomorphic Vessel; G67 Chainlet (bronze) 


\section{Appendix: The hierarchical classification of the artifact types of Szentlörinc ${ }^{1}$}

A: Pottery

A1 Mug

A11 Biconical 1 handled mug

A12 Biconical 2 handled mug

A13 One handled mug

A2 Pot

A21 Biconical pot with knob handle

A22 Biconical pot

A3 Spherical bowl

A31 Spher bowl with Omph

A32 Spherical bowl with Omphalos and retracted rim

A4 Spherical calotte

A5 Bowl with retracted rim

A6 One handled cup

A7 Zoomorphic vessel

B: Jewellery

B1 Hair ring (bronze)

B2 Bracelet

B21 Bracelet (copper)

B22 Bracelet (bronze)

C: Beads

C1 Glass beads

C2 Amber beads

C3 Silver beads

D: Spindle whorls

D1 Spindlewhorl (clay)

D2 Spindlewhorl (bone)

E: Pins

E1 Pin (bronze)

F: Fibuale

F1 Certosa

F11Certosa XIII (bronze)

F111 Certosa XIIIc

F112 Certosa XIIIf

F113 Certosa XIIIh

F12 Certosa (iron)

F2 Eastern Alpine Zoomorphic Fibulae

F21 EAZ (bronze)

F22 EAZ (iron)

F3 ELT (bronze)

1 After NAKoINZ 2005. 
G: Belt attire

G1 Belt clasps

G11 Iron belt clasp

G2 Belt buckle

G21 Iron belt buckle (circular)

G22 Iron belt buckle (quadrangular)

$\mathrm{H}$ : Knives

H1 Iron knife long

H2 Iron knife curved

I: Weapons and attire

I1 Iron spearhead

I11 Iron spearhead short

I12 Iron spearhead long

I2 Arrowhead (iron)

I3 Buttons (iron)

I4 Ring (iron)

$\mathrm{J}$ : Other

J1 Chainlet (bronze)

J2 Stone amulet

J3 Sceptrum (bronze)

J4 Iron awl 